\title{
A POLIHIDROXI-ALKÁNSAVAK ÉS A HIDROGÉN METABOLIZMUS KAPCSOLATA EGY FOTOTRÓF BÍBOR KÉNBAKTÉRIUMBAN
}

\author{
FÜLÖP ANDRÁS
}

TÉMAVEZETŐK:

PROF. KOVÁCS L. KORNÉL

DR. RÁKHELY GÁBOR

\begin{abstract}
BIOLÓGIA DOKTORI ISKOLA
SZEGEDI TUDOMÁNYEGYETEM

TERMÉSZETTUDOMÁNYI ÉS INFORMATIKAI KAR

BIOTECHNOLÓGIAI TANSZÉK
\end{abstract}

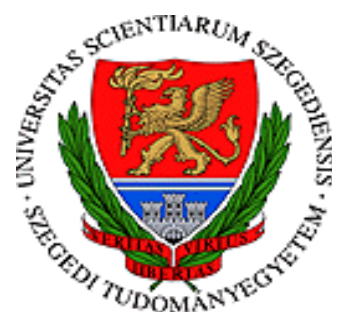

SZEGED

2012 


\section{TARTALOMJEGYZÉK}

TARTALOMJEGYZÉK 2

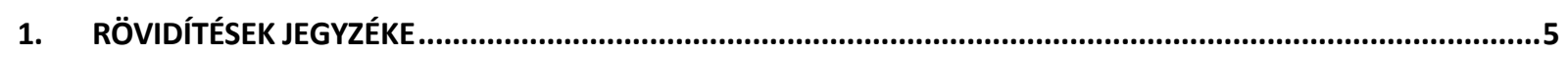

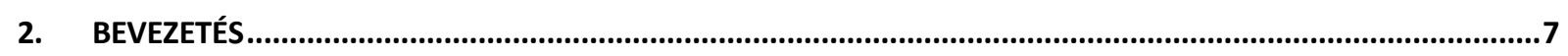

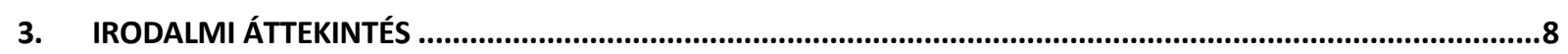

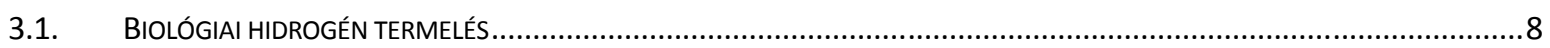

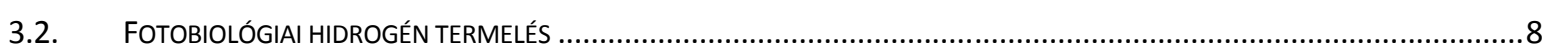

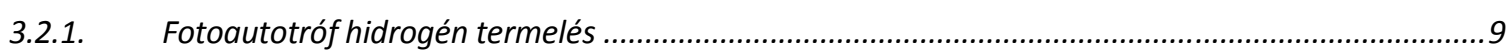

3.2.2. Fotoheterotróf hidrogén termelés ............................................................................................

3.3. A SÖTÉT FERMENTÁCIÓHOZ KAPCSOLT HIDROGÉN TERMELÉS ...........................................................................10

3.4. A HIDROGENÁZOK.................................................................................................................11

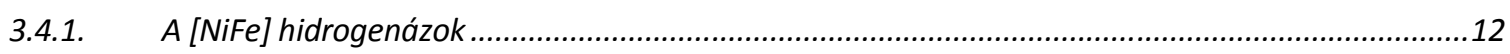

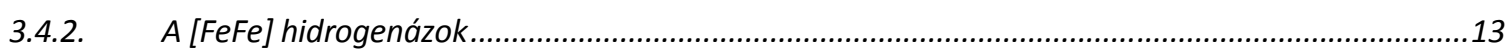

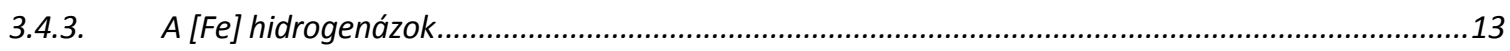

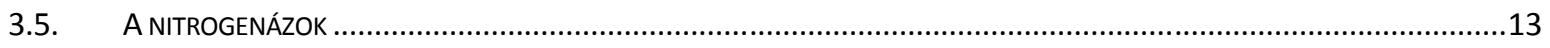

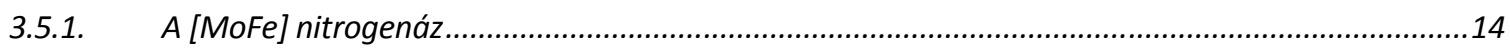

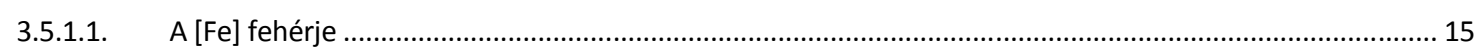

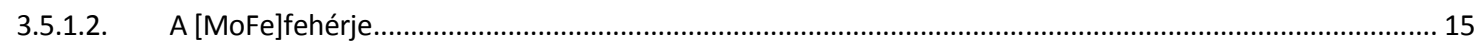

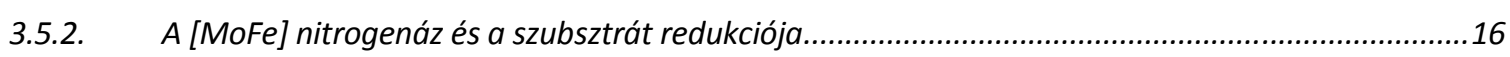

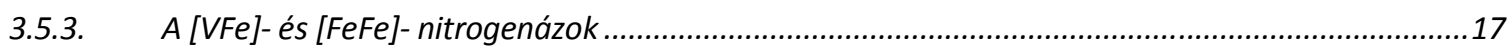

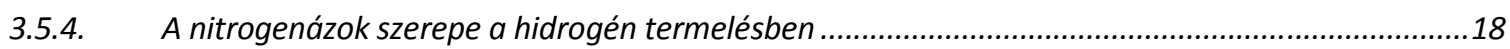

3.5.5. A tartalék tápanyagok szerepe a fototróf mikroorganizmusok anyagcseréjében ........................19

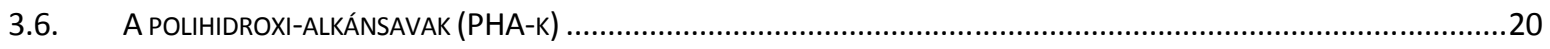

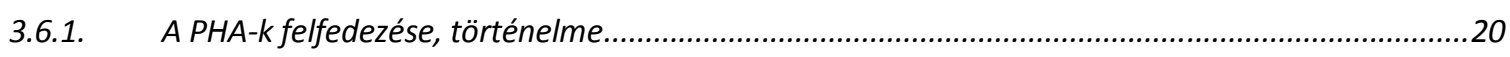

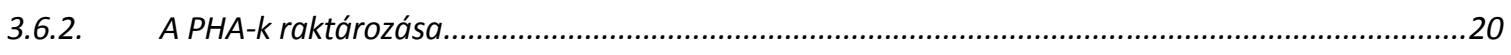

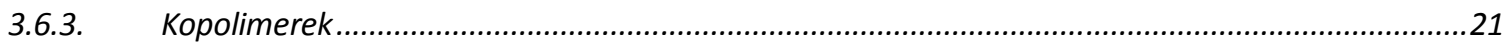

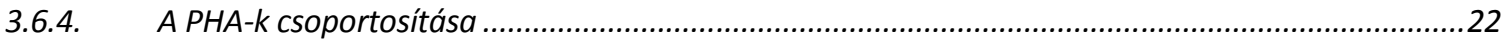

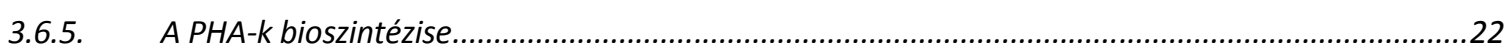

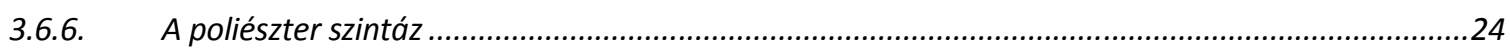

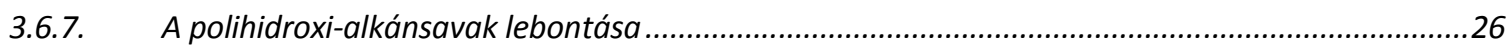

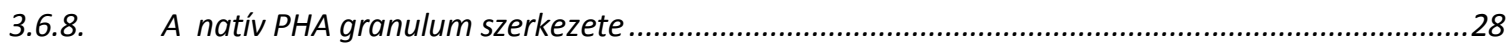

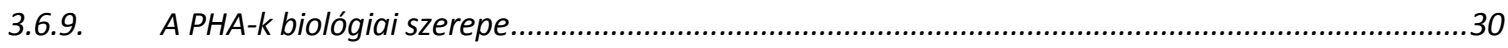

3.6.10. A polihidroxi-alkánsavak ipari előállitása és felhasználása ..........................................................30

3.6.11. A PHA-k raktározása és a hidrogén metabolizmus kapcsolata fototróf mikroorganizmusokban ...31 


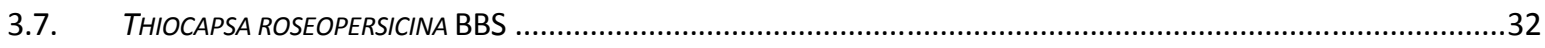

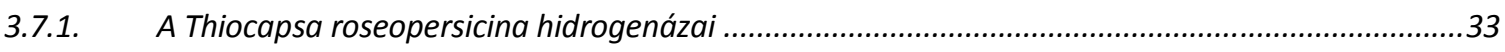

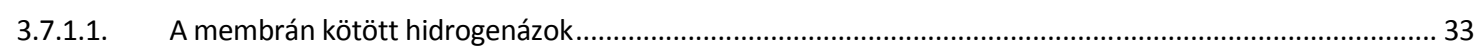

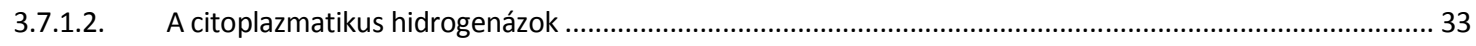

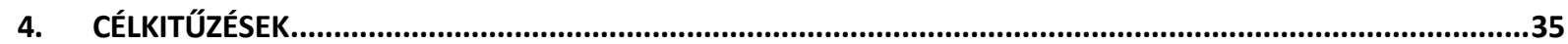

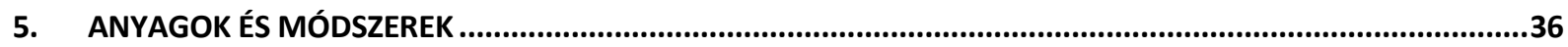

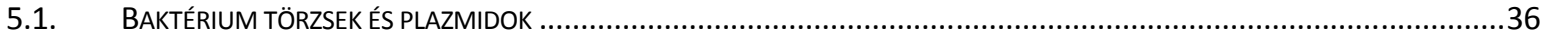

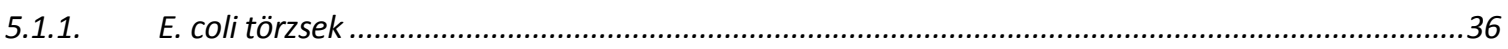

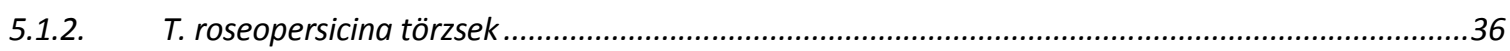

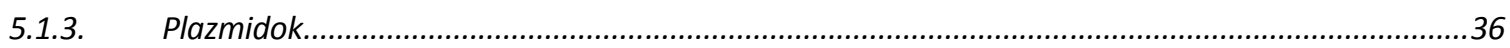

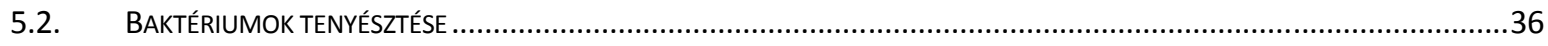

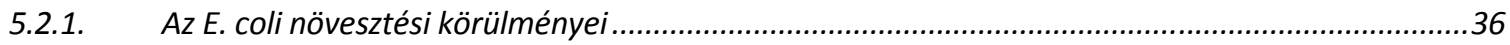

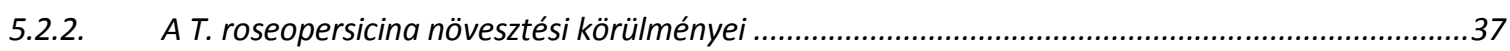

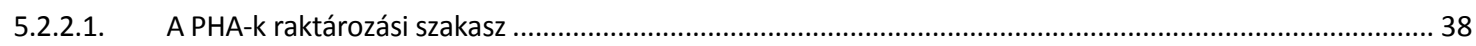

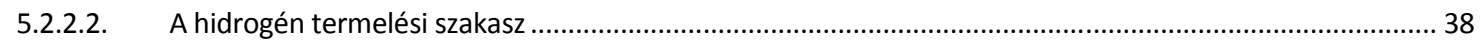

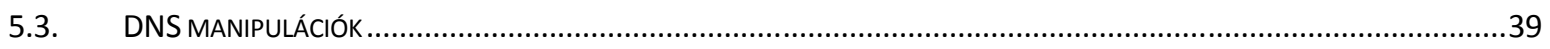

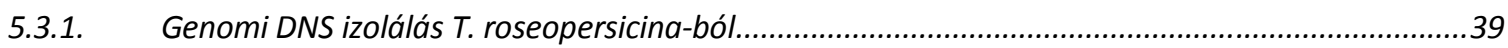

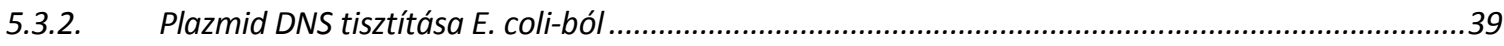

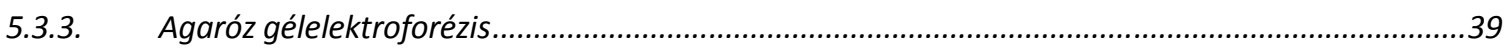

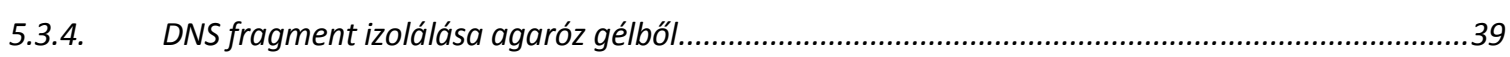

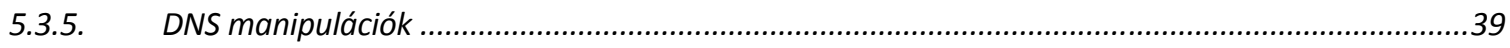

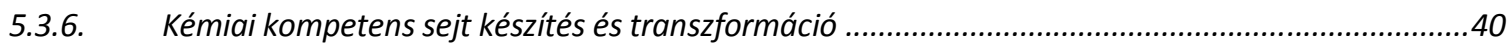

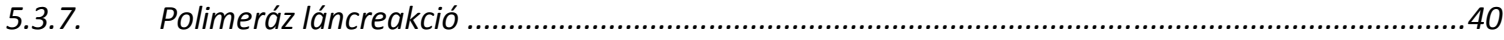

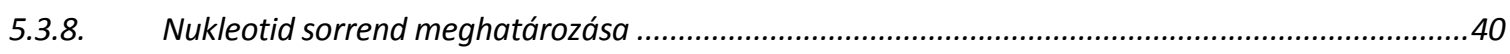

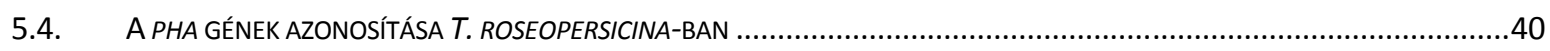

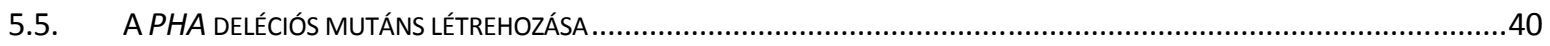

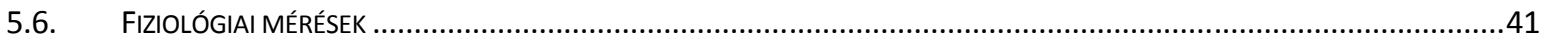

5.6.1. A hidrogén mennyiség mérése ......................................................................................... 41

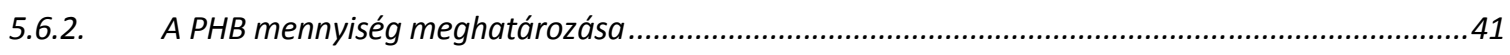

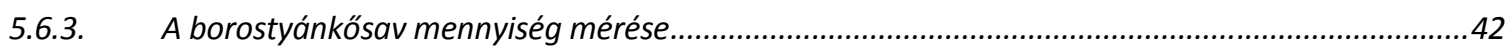

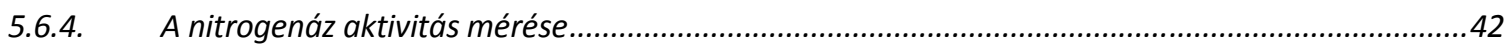

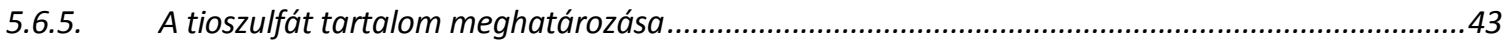

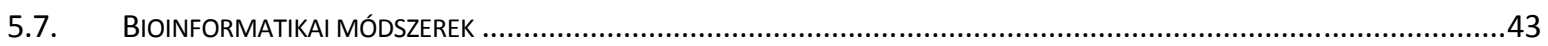

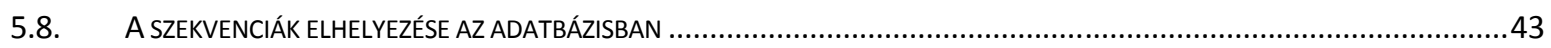

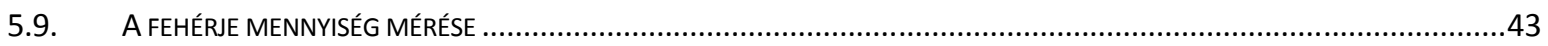

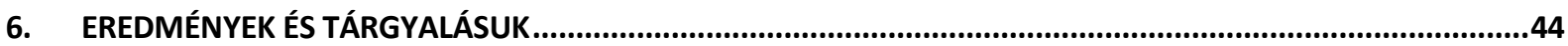




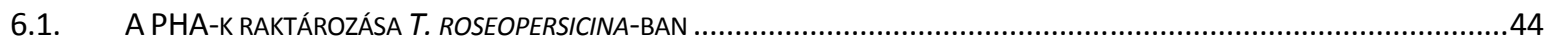

6.2. A PHA METABOLIZMUSBAN RÉSZTVEVŐ GÉNEK AZONOSÍTÁSA THIOCAPSA ROSEOPERSICINA-BAN.................................46

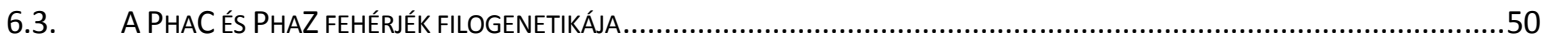

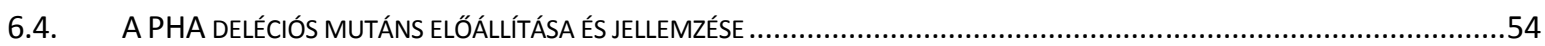

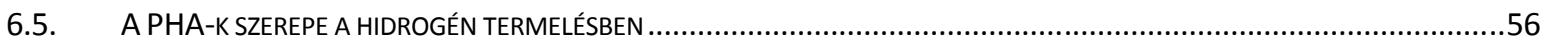

6.6. A TIOSZULFÁT ÉS BOROSTYÁNKŐSAV HATÁSA A PHA-K DEGRADÁCIÓRA ÉS A HIDROGÉN TERMELÉSRE ..............................60

6.7. A THIOCAPSA ROSEOPERSICINA HELYE A GLOBÁLIS HIDROGÉN ANYAGCSERÉBEN ...................................................63

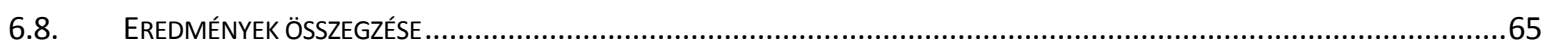

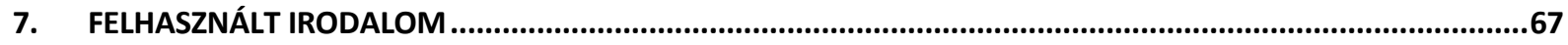

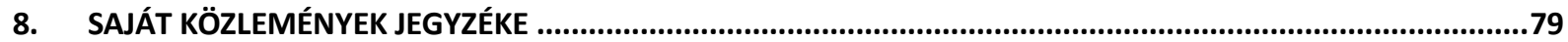

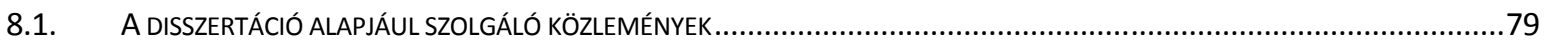

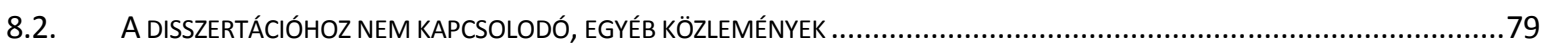

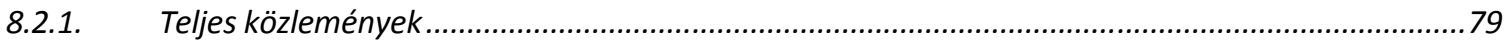

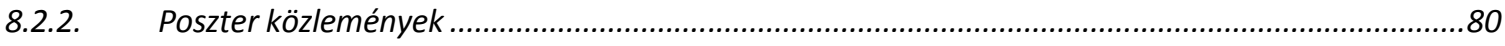

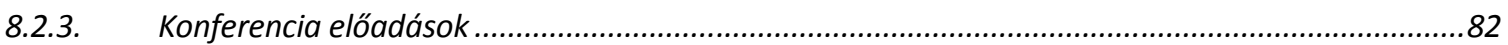

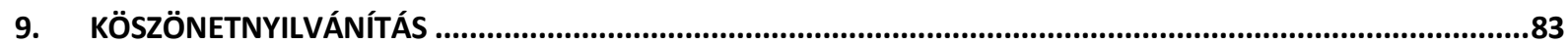

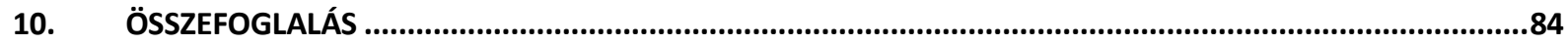

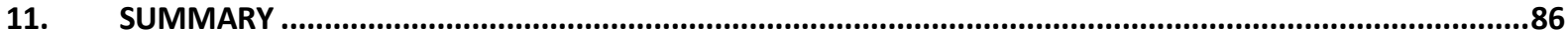




\section{RÖVIDÍTÉSEKJEGYZÉKE}

3-HA: 3-hidroxi-alkánsav

3-HB: 3-hidroxi-vajsav

3-HV: 3-hidroxi-valeriánsav

Amp: Ampicillin

DMSO: dimetil-szulfoxid

dNTP: dezoxinukleozid trifoszfát

dPHA: denaturált polihidroxi-alkánsav szemcse

EDTA: etiléndiamin-tetraecetsav

EPS: exopoliszacharid

HT tápoldat: a hidrogén termelési szakaszhoz használt tápoldat

$\mathrm{Km}$ : kanamicin

LB: Luria-Bertani tápoldat

NAD: nikotinamid-adenin-dinukleotid

NADP: nikotinamid-adenin-dinukleotid-foszfát

NC: nitrogén fixáló körülmények

nPHA: natív polihidroxi-alkánsav szemcse

ORF: nyitott leolvasási keret

PC: fotoautotróf körülmények

PCR: polimeráz láncreakció

PHA: polihidroxi-alkánsav

ksIPHA: közepes szén-láncú polihidroxi-alkánsavak

rsIPHA: rövid szén-láncú polihidroxi-alkánsavak

PHB: polihidroxi-vajsav

PHB4B: poli (3-hidroxi-vajsav-ko-4-hidroxi-vajsav)

PHBV: poli (3-hidroxi-vajsav-ko-3-hidroxi-valeriánsav)

PR tápoldat: a polihidroxi-alkánsavak raktározásához használt tápoldat

rATP: ribo-adenozin trifoszfát

rpm: percenkénti fordulatszám

SDS: nátrium-dodecil-szulfát 
“Igen, barátaim, szentül hiszem, hogy a vizet egy szép napon még tüzelőanyagként fogják fölhasználni, és alkotóelemei, a hidrogén és az oxigén, egymástól elkülönítve; de együttesen alkalmazva, kimeríthetetlen hő- és fényforrást jelentenek majd, hatásfokuk pedig akkora lesz, amekkora szénnel soha el nem érhető. Egyszer még eljön az idő, amikor a gőzösök kamráit és a mozdonyok szerkocsiját szén helyett súrített gázzal töltik meg, amely sohasem sejtett hatásfokú hőmennyiséget termel majd a kazánokban. Nincs tehát mitől félnünk. A föld, amíg csak lakott lesz, ki is elégíti lakói szükségleteit, s az emberiség sohasem szenved majd hiányt sem fényben, sem melegben, mint ahogy nem nélkülözi majd a növényvilág, az ásványvilág vagy az állatvilág termékeit sem. Hiszem tehát, hogy ha a szénbányák egyszer csakugyan kimerülnek, az emberiség vízzel fúti a gépek kazánját s a lakások túzhelyét. A víz a jövő szene."

Jules Verne: A rejtelmes sziget (1874; Fordította: Majtényi Zoltán) 


\section{BEVEZETÉS}

A nagy mértékű technikai fejlődés kényelmesebbé tette életünket, azonban általa az energiafelhasználás nagyságrendekkel növekedett. A 21. században óriási fenyegetést jelent a globális környezeti és energia válság, mellyel most már elkerülhetetlenül szembe kell néznie az emberiségnek. Az élő anyagok az évmilliók alatt, szerves (fosszilis) energiahordozóvá alakultak át. Ezen energiahordozók tartalékainak egyre gyorsuló ütemú felhasználásával, a megkötött szén-dioxid néhány évtized alatt visszakerült a légkörbe, ami a globális klímaváltozást eredményezett (Cammack és mts., 2001; Pimentel, 1991).

Így az emberiség előtt álló egyik legfontosabb feladat a fosszilis energiahordozók minél előbbi kiváltása. A fosszilis energiahordozókat felváltó energiahordozókkal szemben támasztott alapvető elvárások közé tartozik, hogy megújuló forrásból származzanak, környezetbarátok és könnyen tárolhatóak legyenek, valamint hosszú távon képesek legyenek fedezni az egyre növekvő energia igényeket.

A molekuláris hidrogén megfelel a fenti követelményeknek (Cammack és mts., 2001) mivel egy nagyon tiszta energiahordozó, a belőle történő energia felszabadítás során csak víz keletkezik.

A hidrogén előállításához protonokra és alacsony redox potenciállal rendelkező elektronokra van szükség. A ma leggyakrabban használt hidrogéntermelő eljárásokban a $\mathrm{H}_{2}-\mathrm{t}$ kémiai módszerekkel (pl.: a víz elektrolizíse) állítják elő. A fosszilis energiahordozók felhasználásán alapuló kémiai módszereket időszerű lenne felváltania a biológiai úton történő $\mathrm{H}_{2}$ előállítási folyamatoknak, mivel minden biológiai hidrogéntermelési folyamatban az alapvető energiaforrás a Nap és az így termelt hidrogénben eltárolt energia végső soron a Napból érkező és fotoszintézis során megkötött fényenergiából származik, ezért a biológiai úton előállított hidrogén (biohidrogén) megújuló energiahordozó.

A fotoszintézishez számos olyan biokémiai folyamat is kapcsolódik, amely során értékes biopolimerek képződnek és raktározódnak a sejtekben (Fuller, 1995; Price és Kheshgi, 2005). Ezek a fototróf mikroorganizmusok által raktározott biopolimerek (pl. polihidroxi-alkánsavak, glikogén stb.) szén és "redukáló erő" forrást jelentenek, melyek bontása során felszabaduló elektronok, megfelelő körülmények között $H_{2}$ termelésre is felhasználhatóak. 


\section{IRODALMI ÁTTEKINTÉS}

\subsection{BIOLÓGIAI HIDROGÉN TERMELÉS}

A biológiai hidrogén termelő folyamatok a következő képen csoportosithatóak:

1. Fotobiológiai hidrogén termelés

a) Fotoautotróf hidrogén termelés

b) Fotoheterotróf hidrogén termelés

2. Sötét fermentációhoz kapcsolt hidrogén termelés

3. Egyéb folyamatokhoz kapcsolt hidrogén termelés

A biológiai rendszerekben jelenleg két olyan enzimcsalád ismert, amely képes hidrogén termelésére vagy oxidációjára, ezek a hidrogenázok illetve a nitrogenázok.

A hidrogenáz enzimek olyan ősi fehérjék, amelyek a természetben előforduló legegyszerúbb molekula, a $\mathrm{H}_{2}$ képződését vagy elbontását katalizálják, vagyis kizárólag a hidrogén-metabolizmusra specializálódtak.

A nitrogenázok fő feladata a légköri nitrogén megkötése, melynek során jelentős mennyiségú $\mathrm{H}_{2}$ szabadul fel.

Korábbi közleményekben leírták, hogy a biológiai hidrogén termelés hatékonyságát alapvetően két fő tényező határozza meg: a hidrogenázok és nitrogenázok aktivitása és mennyisége a sejtekben (Hallenbeck és Benemann, 2002), valamint a különböző metabolikus folyamatok során, ezen enzimekre irányuló elektronáramlás mértéke (Jeong és Jouanneau, 2000).

\subsection{FOTOBIOLÓGIAI HIDROGÉN TERMELÉS}

A fotóbiológiai hidrogén termelésre a fotoautotróf és fotoheterotróf mikroorganizmusok képesek. A mikro algák és a cianobaktériumok és egyes bíbor baktériumok fotóautróf hidrogén termelők, mivel képesek a $\mathrm{CO}_{2}-\mathrm{t}$, mint egyetlen szénforrást fényenergia segítségével hasznosítani. A fotoheterotróf hidrogén termelők a nitrogén fixáló mikroorganizmusok, melyek a nitrogenáz enzimet használják ehhez a folyamathoz. 


\subsubsection{FOTOAUTOTRÓF HIDROGÉN TERMELÉS}

A mikroalgák és cianobaktériumok, az aerob fotoszintézis során a fényenergia segítségével, a $\mathrm{CO}_{2}-\mathrm{t}$, energia gazdag szerves komponensek $\left[\mathrm{C}_{n}\left(\mathrm{H}_{2} \mathrm{O}\right)_{n}\right]$ szintézisére használják fel.

Anaaerob körülmények között ezen organizmusok kettes fotokémiai rendszer (PSII) a közvetlen fotolízis révén a elhasítja a víz molekulát és a keletkező elektronok a ferredoxinon (Fd) keresztül a hidrogenázra kerülnek és hidrogén termelésre felhasználhatóak.

A hidrogenáz múködését és a vízbontást mindenképp el kell választani egymástól (ez a közvetett fotolízis), mert a keletkező oxigén inaktiválja a hidrogenázokat (Sasikala és mts., 1993) és expressziójukat is gátolja (Sawers és mts., 1999). Ha a két folyamatot időben elválasztjuk egymástól a felszabaduló elektron energiája széndioxid asszimilációra,illetve keményítőképzésre fordítódik és sötétben, anaerob körülmények között, amikor a fotoszintézis szünetel, a tartaléktápanyagban raktározott energia hidrogéntermelésre fordítható.

Erre egy nagyon jó példa a heterocisztás cianobaktériumok. A heterociszták olyan specializálódott sejtek, melyekben nem történik vízbontás, így a nitrogenáz védett az $\mathrm{O}_{2}$ gátló hatásától. Ezen sejteket a vegetatív sejtek látják el szubsztrátokkal és tápanyaggal. Habár a közvetlen biofotolízis kecsegtető lehetőséget kínál a hidrogén termelésre, a hidrogenázok $\mathrm{O}_{2}$ érzékenysége és a fényenergia átalításának kis hatékonysága limitáló tényezők.

A bíbor kén fotoszintetizáló baktériumok néhány képviselője képes úgyancsak fotoautotróf hidrogén termelésre, de mivel egyetlen fotorendszerúk víz bontására nem képes, ezért elektrondonorként redukált szerves kénvegyületeket használnak (pl. Thiocapsa roseopersicina ;Pfennig és Trüpper, 1991).

\subsubsection{FOTOHETEROTRÓF HIDROGÉN TERMELÉS}

A bíbor fotoszintetizáló baktériumok csak egy fotokémiai rendszerrel rendelkeznek, mely nem képes a víz bontására. Ezen baktériumok, anaerob körülmények között, kis szerves szubsztrátokból nyerik az elektronokat, melyek a membrán, elektrontranszportban részt 
vevő komponenseire kerül. Az elektrontranszport lánc múködése során protongradiens alakul ki, mely ATP szintézisre fordítódik.

A hidrogén termelést itt a nitrogenázok katalizálják, a ferredoxin által továbbított elektronokat használva. Ammónia hiányában ezen elektronok, az ATP-ben raktározott energiát felhasználva, a légköri nitrogén fixálására fordítódnak és melléktermékként hidrogén képződik. $\mathrm{N}_{2}$ hiányában ezen enzim ATP függő hidrogenázként múködik és az összes, ferredoxin által továbbított elektront $\mathrm{H}_{2}$ termelésre használja fel (Thorney és Lowe, 1983; Liang és Burris, 1988).

Ezen hidrogéntermelő rendszer hátránya a reakció nagy energiaigénye (4 ATP/ $\mathrm{H}_{2}$ ).

\subsection{A SÖTÉT FERMENTÁCIÓHOZ KAPCSOLT HIDROGÉN TERMELÉS}

Számos anaerob mikroorganizmus képes hidrogént termelni. Ezen mikroorganizmusok a szerves szubsztrátokat (hexóz) kisméretű szerves savakká (ecetsav, vajsav, tejsav stb.) redukálják, miközben a sejten belüli folyamatok számára elegendő energiát termelnek (Akkerman és mts., 2003). Ezen folyamatokhoz nem szükséges plusz energiát befektetni, mint a fotobiológiai hidrogén termelés esetében a fényenergiát.

$\mathrm{Az}$ anaerob és fakultatív anaerob mikroorganizmusokban a metabolikus folyamatokhoz sajátos mechanizmusok szükségesek, hogy a sejtekben szabályozzák az elektronok áramlását. Ezen szabályozó mechanizmusok egyike a mikroorganizmusok azon képessége, hogy a hidrogenázok által termelt hidrogén formájában képesek megszabadulni a fölösleges elektronoktól. Nagyon gyakran ezen hidrogenázok képesek a hidrogén visszavételére is. A hidrogén oxidációja során nyert elektronok a quinon raktáron keresztül a $\mathrm{NAD}^{+}$redukciójára fordítódnak. Ezen hidrogenázok szerepe a redukáló ágensek termelése, mely felhasználhatóak a különböző sejten belüli folyamatokban (Akkerman és mts., 2003).

A sötét fermentáción alapuló hidrogén termelés egyik előnye, hogy a mikroorganizmusok szerves szubsztrátokat használva éjjel-nappal képesek hidrogént termelni.

A szigorúan anaerob Clostridia fajok, egyes bél- és termofil baktériumok, mint Caldicellulosiruptor fajok a legjobb hidrogén termelők közé tartoznak. 
A szigorúan anaerob fajok rendkívül érzékenyek az $\mathrm{O}_{2}$, de kevert kultúrákban alkalmazva, a fakultatív anaerobok nagyon gyorsan képesek elhasználni az $\mathrm{O}_{2}$ és a bioreaktorban visszaállítani az anaerob körülményeket.

A fakultatív anaerobok mintaként szolgálhatnak, hogy oxigén toleráns hidrogenázokat találjunk és az erre irányuló kutatások nagyon ígéretesek a biohidrogén jövője szempontjából (Duche és mts., 2005; Vincent és mts., 2007).

\subsection{A HidrogenázoK}

A hidrogenázok olyan fém tartalmú enzimek, amelyek képesek a hidrogén bontását és képződését is katalizálni (Cammack és mts., 2001; Vignais és Billoud, 2007; Vignais, 2008).

$$
2 \mathrm{H}^{+}+2 \mathrm{e}^{-} \Rightarrow \mathrm{H}_{2} \quad \mathrm{H}_{2} \Rightarrow 2 \mathrm{H}^{+}+2 \mathrm{e}^{-}
$$

A reakció reverzibilis és irányítottsága az enzimmel kölcsönható $\mathrm{H}_{2} / \mathrm{H}^{+}$illetve a másik partner aktuális redox potenciáljától függ.

$A z$ enzimek sokszor előnyben részesítik a hidrogén felvételét, vagy a hidrogén termelését, de vannak "kétirányú" hidrogenázok, melyek mindkét folyamatot képesek katalizálni a sejt redox állapotától függően (Vignais és Billoud, 2007; Vignais, 2008).

A hidrogenázok főleg Archeabaktériumokban és Eubaktériumokban fellelhető enzimek, de néhány eukarióta organizmusban (pl.: algákban) is megtalálhatóak (Vignais, 2008).

A molekuláris hidrogénből származó elektronokat számos mikroba hasznosítja aerob vagy anaerob energia-konzerváló folyamatokban (pl.: metanogenezis, szulfát redukció, fotoszintetikus $\mathrm{CO}_{2}$ fixáció, anaerob légzés (Vignais és Billoud, 2001; Vignais, 2008).

A sejtekben található hidrogenázok eltérhetnek sejten belül betöltött szerepükben, elhelyezkedésükben, redox partnereikben és felépítésükben is.

A hidrogenázokat az aktív centrum fém tartalma alapján, három fó csoportba sorolják: Ni és Fe atomot tartalmazó [NiFe]-, a két Fe atomot tartalmazó [FeFe]-, illetve Fe-S kockákat nem tartalmazó és speciális Fe tartalmú kofaktort tartalmazó hidrogenázok (Hmd enzim, [Fe]-hidrogenázok). A három fő osztályon belül a hidrogenázokat tovább 
csoportosítják a specifikus elektron donorok és akceptorok (NAD, citokrómok, F420 koenzim, vagy ferredoxinok), illetve az enzim elhelyezkedése alapján (membrán kötött, citoplazmatikus enzimekre (Vignais és Billoud, 2007).

\subsubsection{A [NIFE] HIDROGENÁZOK}

A [NiFe]- hidrogenázok a leggyakoribb és a legalaposabban tanulmányozott hidrogenázok. Heterodimer felépítésű enzimek, melyek egy kb. 60 kDa méretű nagy és egy kb. 30 kDa-os kis alegységet tartalmaznak (1. ábra). Az alegységek mérete konzervált. A nagy alegység tartalmazza az aktív centrumot. A kis alegység tartalmaz két [4Fe-4S] és egy [3Fe4S] kockát, melyek az elektronok az aktív centrum/a fehérje felszíni régiói felé, vagy a redox partner irányában történő szállításában játszanak szerepet (Cammack és mts., 2001). Ezen hidrogenázok [NiFe] aktív centruma a nagy alegységben található, melyet négy cisztein aminosav formálta diszulfid hidak rögzítik a fehérjéhez. A vas atomhoz speciális ligandok, egy CO és két CN csoport kapcsolódik (Volbeda és mts., 1995; Fontecilla-Camps és mts., 1997).

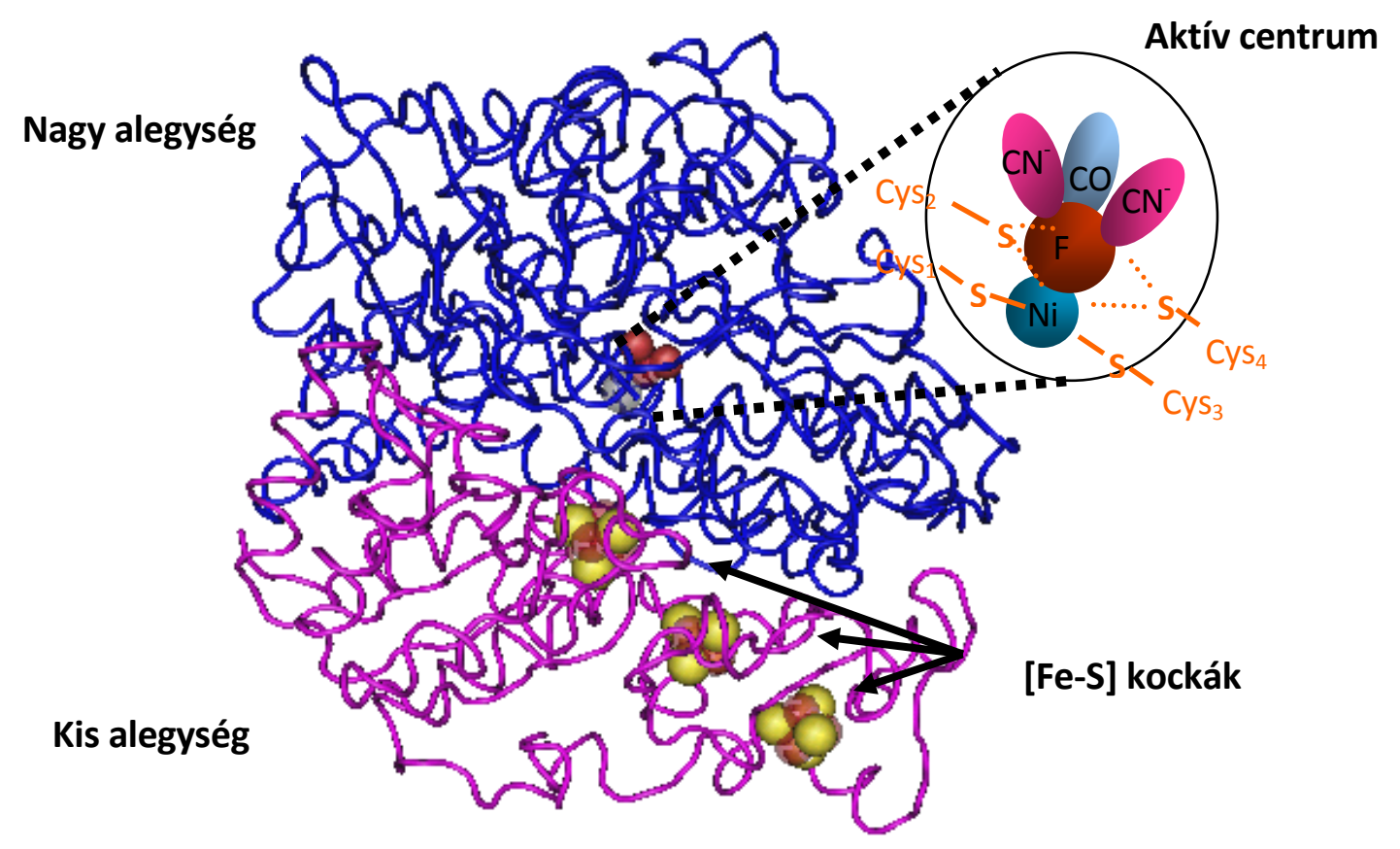

1. ábra. A Desulfovibrio vulgaris NiFe hidrogenázának kristályszerkezete (Frey, 2002). 


\subsubsection{A [FEFE] HIDROGENÁZOK}

Ezen hidrogenázok az anaerob fermentatív, szulfátredukáló baktériumokban fordulnak elő, és az egyetlen, eukariótákban is megtalálható enzimek. A [FeFe] hidrogenázok katalitikus centruma, az ún. H-klaszter egy [4Fe-4S] kockát tartalmaz, melyet egy cisztein egy 2Fe alkötéshez kapcsol. Mindkét vasatomhoz egy-egy $\mathrm{CO}$ és $\mathrm{CN}^{-}$ligand kötődik. A [FeFe] hidrogenázok között találunk monomereket, homodimereket, de akár heterotrimer vagy heterotetramer szerkezetűeket is (Fritsche és mts., 1999; Vignais és mts., 2001).

\subsubsection{A [FE] HIDROGENÁZOK}

A [Fe] hidrogenázokat szerepük alapján $\mathrm{Hmd} \quad \underline{\underline{H}}_{2}$ termelő meteniltetrahidrometanopterin dehidrogenáz) hidrogenázoknak is nevezik. Két, azonos méretű (38 kDa) alegységet tartalmaznak. Methanothermobacter marburgensis-ben felfedezett és leírt homodimer enzimek, melyek aktív centrumában egyetlen, nem redox aktív Fe atom helyezkedik el egy speciális piridon kofaktorhoz kötötten (Shima és mts., 2007). Ezen enzimek nem tartalmaznak [Fe-S] kockákat. Számos metanogén baktériumban a $\mathrm{CO}_{2}$ és a $\mathrm{H}_{2}$ metánná való konverzióját katalizálják (Thauer, 1998), de nem képesek az alábbi reakciót katalizálni: $2 \mathrm{H}^{+}+2 \mathrm{e}^{-} \Leftrightarrow \mathrm{H}_{2}$.

\subsection{A NiTROGENÁZOK}

A nitrogén az élethez nélkülözhetetlen kémiai elem, számos kulcsfontosságú biomolekula ( $\mathrm{pl}$. fehérjék, nukleinsavak stb.) fontos komponense. A bioszféra legnagyobb nitrogén raktára a légköri nitrogén $\left(N_{2}\right)$, ami kémiailag semleges $N$ forrást jelent. Ez a legtöbb élőlény számára elérhetetlen. A nitrogenázok alapvető szerepe a légköri $\mathrm{N}_{2}$ bejuttatása a biogeokémiai $\mathrm{N}$ ciklusba. $\mathrm{A} \mathrm{N}_{2}$ redukció során két molekula ammónia keletkezik. A nitrogenáz egy nagy energia igényű, fémtartalmú katalizátor, mely kizárólag prokariótákban (Eubaktériumokban és Archeabaktériumokban) fordul elő.

Jelenleg négy különböző típusú nitrogenázt ismerünk, melyek mindegyike egyedi génkészlet által kódolt (nif, vnf, anf, st), sajátos fémtartalmú aktív centrummal rendelkezik (Burgess és Lowe, 1996; Eady, 1996). 
A négy ismert nitrogenáz:

- a molibdén tartalmú nitrogenáz ([MoFe] nitrogenáz)

- a vas tartalmú nitrogenáz ([FeFe] nitrogenáz)

- a vanádium tartalmú nitrogenáz ([VFe] nitrogenáz)

- a Streptomyces thermoautotrophicus nitrogenáza (St-nitrogenáz)

A nitrogenázok első három típusa szerkezetileg hasonló. Eltérést csak az aktív bimetál centrumokban találunk, ahol a vas mellett molibdént ([MoFe] nitrogenáz), egy másik vas atomot ([Fe-Fe] nitrogenáz), illetve vanádium atomot ([V-Fe] nitrogenáz) tartalmaznak. A legszélesebb körben előforduló a [MoFe] nitrogenáz, mely - az S. thermoautotrophicus-t kivéve - minden nitrogén fixálásra képes organizmusban előfordul és az elsődleges nitrogenáz.

A [Fe-Fe] illetve a [V-Fe] alternatív nitrogenázok előfordulása teljesen véletlenszerű (Newton, 2005). A három nitrogenáz kifejeződését a környezet Mo és V tartalma határozza meg (Pau, 1994). A nitrogenázok kifejeződésének "fémfüggősége" fiziológiailag előnyős, mivel a nitrogén redukciót a leghatékonyabb a [Mo-Fe] nitrogenáz katalizálja, ezt követi a [VFe] nitrogenáz, majd a [Fe-Fe] nitrogenáz, mely a legkevésbé hatékony.

A S. thermoautrophicus termofil baktériumban egy egyedi nitrogenázt (Stnitrogenázt) írtak le, mely sajátos szerkezettel rendelkezik. A [MoFe] nitrogenázhoz való hasonlósága kimerül abban, hogy a fehérje ugyancsak két alegységből épül fel és Mo, Fe és $\mathrm{S}^{2-}$ tartalmaz (Ribbe és mts., 1997).

\subsubsection{A [MOFE] NITROGENÁZ}

A leggyakoribb és legismertebb nitrogenáz, mely aktív centrumában [FeMo] kofaktort helyezkedik el. Az enzim két alegységet tartalmaz: a [Fe] fehérjét (dinitrogenáz reduktázt vagy II. komponenst) és molibdén-vas [MoFe] fehérjét (dinitrogenázt vagy I. komponenst). A nitrogenáz az alábbi reakciót katalizálja:

$$
\mathrm{N}_{2}+8 \mathrm{e}-+8 \mathrm{H}^{+}+16 \mathrm{ATP} \longrightarrow 2 \mathrm{NH}_{3}+\mathrm{H}_{2}+16 \mathrm{ADP}+16 \mathrm{Pi}
$$




\subsubsection{A [FE] FEHÉRJE}

A [Fe] fehérje (nifH) egy kb. 64 kDa méretű két azonos alegységet tartalmazó fehérje. Mindegyik alegység egy MgATP/MgADP kötő helyet tartalmaz a fehérje belsejében. A két alegységet egyetlen [4Fe-4S] centrum kapcsolja össze (Georgiadis és mts., 1992).

A $N_{2}$ fixálás mechanizmusában a [Fe] fehérjének három fő szerepe van (Newton, 2005 ; Burgess és Lowe, 1996 ):

- a [MoFe] fehérje elektron donorja,

- MgATP hidrolíziséhez kapcsolt egyirányú- hatékony elektrontranszfert tesz lehetővé a [MoFe] fehérje irányába,

- részt vesz a [MoFe] fehérje bioszintézisében és érésében.

Továbbá, szerepe lehet az alternatív nitrogén fixáló rendszerek szabályozásában is.

\subsubsection{A [MOFE]FEHÉRJE}

A [MoFe] fehérje (nifDK) egy $\alpha_{2} \beta_{2}$ struktúrát mutató tetramer szerkezetű fehérje, melynek molekulatömege 230 kDa. A fehérje két pár sajátos csoportba szerveződő fém centrumot tartalmaz: a $\mathrm{P}$ struktúrát ([8Fe-7S]) és a [FeMo] kofactort ([7Fe-Mo-9Shomocitrát-X]).

Minden $\alpha$ alegység belsejében egy-egy [FeMo] kofaktor helyezkedik el, míg a P struktúra a fehérje felszín közelében, az $\alpha \beta$ alegységek összekapcsolódásánál lokalizálódik (2A. ábra).

Számos kísérlet igazolta, hogy a $P$ struktúra elsődleges funkciója a [Fe] fehérjétől származó elektronok tárolása, majd továbbítása a [FeMo] kofaktorhoz kapcsolódó szubsztrátra (Peters és mts., 1997).

A [FeMo]-kofaktor a szubsztrát kötődés és redukció helye. A fémkötések, [4Fe-3S] és a [3Fe-Mo-3S] centrumokba rendeződnek, melyeket az ismeretlen X- atom és három szervetlen szulfid kapcsol össze.

A Mo atomhoz továbbá kapcsolódik egy R-homocitrát is, melynek szerepe még szintén nem teljesen tisztázott. 

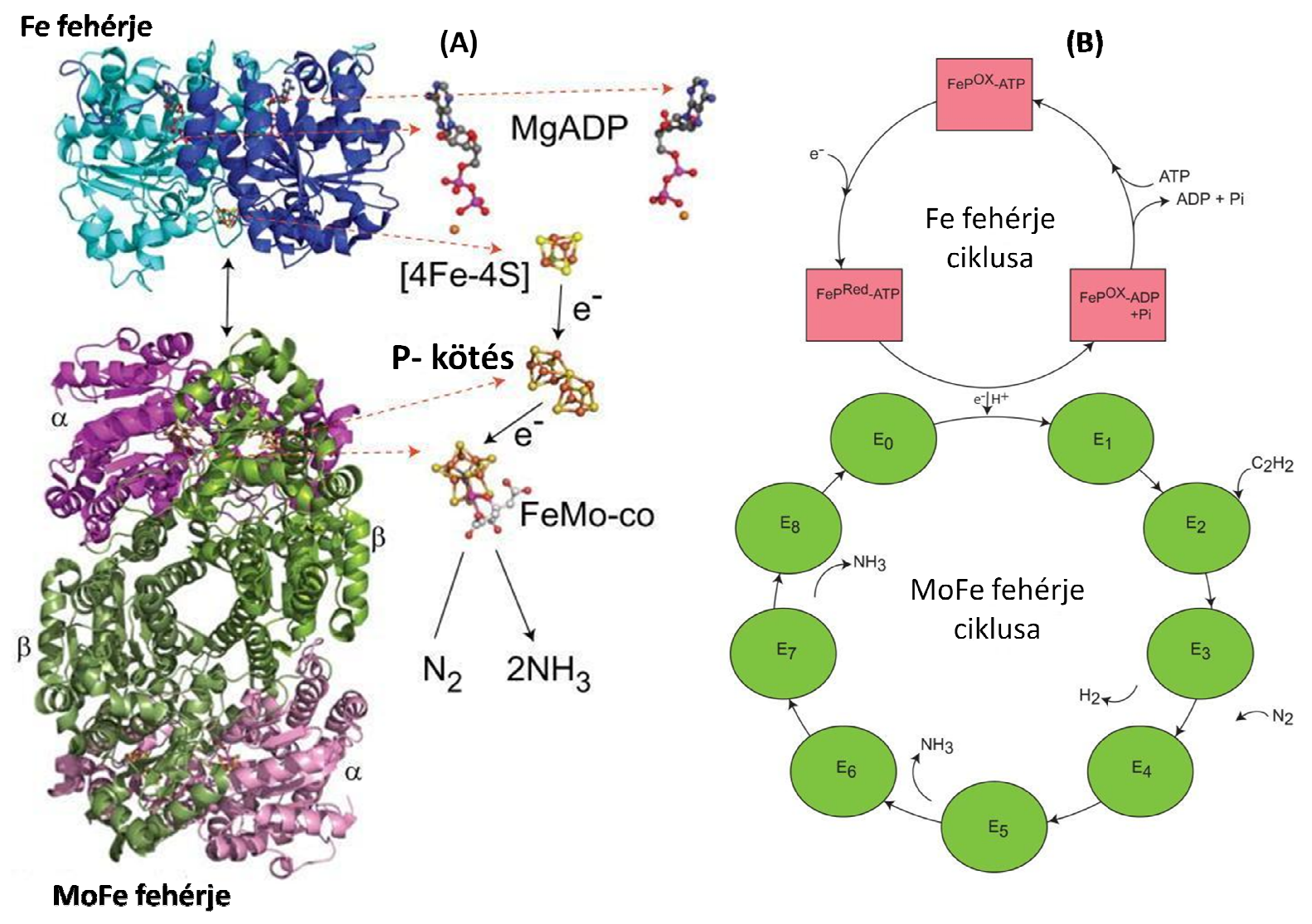

2. ábra. A [Fe] fehérje és a [MoFe] fehérje szerkezete (A) és ciklusa (B) (Seefeldt és mts., 2009)

\subsubsection{A [MOFE] NITROGENÁZ ÉS A SZUBSZTRÁT REDUKCIÓJA}

A szubsztrát redukcióhoz a [MoFe] és [Fe] fehérjék összekapcsolódása szükséges, mely egy komplexet alkotva képes a MgATP hidrolízisére, illetve az ehhez kapcsolt intramolekuláris elektron transzfer előfeltétele.

A röntgen krisztallográfiai vizsgálatok (Jang és mts., 2000; Chiu és mts., 2001) azt mutatják, hogy az Azotobacter vinelandii nitrogenázában a két fehérje egy $\left(\alpha \beta \gamma_{2}\right)_{2}$ szerkezetű oktamer struktúrát vesz fel, melyben minden $\alpha \beta$ [MoFe] fehérje alegység egy [Fe] fehérjét $\left(\gamma_{2}\right)$ tartalmaz.

A nitrogenáz múködésének átfogó kinetikai modellje (2B. ábra) megmutatja a katalitikus reakció minden egyes lépését (Lowe és Thorneley, 1984). A modell alapját két egybefonódó ciklus képezi: a [Fe] fehérje és a [MoFe] fehérje redox ciklusa. A Fe fehérje szerepe a nitrogenáz múködésben egy három lépésből álló folyamatként határozható meg, 
mely során két MgATP hidrolíziséhez kapcsoltan, egy elektron továbbítódik a [FeMo] kofaktor felé.

A $\mathrm{N}_{2}$ redukció során a [FeMo] kofaktornak nyolc elektront kell fogadnia, miközben minden [Fe] fehérje megkötésekor csak egy elektron továbbítódik. A [Fe] fehérje egy elektronos ciklusa és a [MoFe] fehérje 8 elektronos ciklusa $\left(E_{0}-E_{8}\right)$ összekapcsolódik, mely a [MoFe] fehérje folyamatos redukáltságához vezet.

A nitrogenáz múködésének ezen modellje, számos lényeges megfigyelést ábrázol. Például ismert, hogy a [MoFe] fehérjének három vagy négy elektront ( $E_{3}$ vagy $\left.E_{4}\right)$ kell raktároznia a $\mathrm{N}_{2}$ megkötése előtt (Thorneley és Lowe, 1985), továbbá a $\mathrm{N}_{2}$ megkötése egy $\mathrm{H}_{2}$ molekula felszabadulásával jár (Liang és Burris, 1988; Simpson és Burris, 1984). A nitrogén molekula hiányában, a [MoFe] fehérje csak alacsony redukáltsági (En) állapotba juthat, miközben $\mathrm{H}_{2}$-t termel. A $\mathrm{N}_{2}$ és proton mellett a nitrogenáz számos kisméretű kettős illetve hármas kötést tartalmazó vegyületet képes redukálni, pl. az acetilén $\left(\mathrm{C}_{2} \mathrm{H}_{2}\right)$ redukciója etilénné $\left(\mathrm{C}_{2} \mathrm{H}_{4}\right)$. Ez a leggyakrabban használt módszer a nitrogenáz aktivitás nyomon követésére (Burgess és Lowe, 1996).

\subsubsection{A [VFE]- ÉS [FEFE]- NITROGENÁZOK}

Az aktív centrumban vanádiumot tartalmazó [VFe] nitrogenázt találtak számos aerob(pl.: A. vinelandii), fototróf baktériumban (pl.: Anabena variabilis) illetve Archeában (pl.: Methanosarcina barkeri) is.

A [FeFe] nitrogenázt előszőr $A$. vinelandii-ban azonosították Chisnell és mts., (1988). További [FeFe] nitrogenázt találtak, Rhodobacter capsulatus és Rhodospirillum rubrum fajokban is.

Mind a [VFe], mind a [FeFe] fehérjék az $\alpha$ és $\beta$ alegység mellett tartalmaznak, egy harmadik $\delta$ alegységet, melynek eredménye egy $\alpha_{2} \beta_{2} \delta_{2}$ összetétel. A [VFe] és [FeFe] nitrogenázok aktivitásához nélkülözhetetlenek a $\delta$ alegységek ( 15 kDa). Ezek a [VFe] (feltehetően a [FeFe] fehérjék esetében is) fehérjék bioszintézise során és azt követően is a fehérjéhez kapcsoltak. Ezzel ellentétben a [MoFe] fehérjék esetében a $\delta$ alegység, az érés nagyon késői szakaszában leválik a fehérjéről. A [VFe] és a [FeFe] fehérjék is tartalmaznak P szerkezetet és kofaktorokat. 
A különböző fajokból származó [MoFe] nitrogenázok összehasonlítása során tapasztalt szekvencia azonosság, a különböző [VFe], illetve a [FeFe] nitrogenázok esetében is megfigyelhető. Ez a nagyfokú azonosság azt sugallja, hogy ezen nitrogenázok hasonló szerkezeti és múkődési sajátosságokkal rendelkező ősi enzimek.

\subsubsection{A NITROGENÁZOK SZEREPE A HIDROGÉN TERMELÉSBEN}

A különböző katalitikus fémtartalommal rendelkező enzimek nagyon eltérő hatékonysággal termelnek hidrogént. Ugyan mindegyik enzim termel némi hidrogént miközben a $\mathrm{N}_{2}$-t ammóniává redukálják, de a sztöhiometriájuk nagyon különböző (Eady, 1996).

Molibdén enzimek: $\mathrm{N}_{2}+8 \mathrm{H}^{+}+8 \mathrm{e}^{-} \rightarrow 2 \mathrm{NH}_{3}+1 \mathrm{H}_{2}$

Vanádium enzimek: $\mathrm{N}_{2}+12 \mathrm{H}^{+}+12 \mathrm{e}^{-} \rightarrow 2 \mathrm{NH}_{3}+3 \mathrm{H}_{2}$

Vas enzimek: $\mathrm{N}_{2}+21 \mathrm{H}^{+}+21 \mathrm{e}^{-} \rightarrow 2 \mathrm{NH}_{3}+7.5 \mathrm{H}_{2}$

Mivel ezen reakciók meglehetősen nagy energia igénnyel rendelkeznek (2 ATP/ elektron; Eady, 1996), minden egyes $\mathrm{H}_{2}$ molekula előállításához 4 ATP-re van szükség. A $\mathrm{N}_{2}$ redukcióhoz kapcsolt $\mathrm{H}_{2}$ termelés nagy pazarlásnak tűnik, de ez, az enzim megfelelő múködéséhez nélkülözhetetlen folyamat. Emellett számos mikroorganizmus rendelkezik hidrogén visszavételre képes (uptake) hidrogenázzal és így képesek visszanyerni a befektetett energia egy részét (Vignais és Billoud, 2007).

A nitrogenázok, $\mathrm{N}_{2}$ hiányában is megőrzik protonredukáló aktivitásukat. ATP függő hidrogenázként múködve az összes elektront $\mathrm{H}_{2}$ termelésére fordítják, növelve a folyamat hatékonyságát (Thorneley és Lowe, 1983; Simpson és Burris, 1984; Joshi és Tabita, 1996).

A. vinelandii sejtekben, a [Fe] fehérje hiányában, a [MoFe] fehérje hidrogén visszavevő aktivitással rendelkezik (Wang és Watt, 1984 ).

A nitrogén redukció verseng a hidrogén termeléssel, vagyis ha a kísérletek a hidrogén termelés fokozására irányulnak, ajánlatos hogy a rendszer ne tartalmazzon $\mathrm{N}_{2}-\mathrm{t}$, mert ha a molekuláris $\mathrm{N}_{2}$ jelen van a az elektronok közel 75\%-a nitrogén redukcióra fordítódik és csak az elektronok fennmaradó 25\%-a használódik fel $\mathrm{H}_{2}$ termelésére (Burris, 1991). A nagy 
energiaigény mellett, a nitrogenázok nagyon oxigén érzékeny, illetve viszonylag lassú $\left(10^{-1} \mathrm{~s}\right.$ os) katalitikus ciklussal rendelkező enzimek.

A nitrogenázokat és a hidrogenázok hidrogén termelését összehasonlítva a nitrogenázokhoz kapcsolt hidrogén termelés mellett szól a jelentős termodinamikai hajtóerő, melyet az ATP hidrolízis szolgáltat.

\subsubsection{A TARTALÉK TÁPANYAgOK SZEREPE A FOTOTRÓF MIKROORGANIZMUSOK ANYAGCSERÉJÉBEN}

A mikroorganizmusok azon képessége, hogy a folyamatosan változó körülmények között a feleslegben levő tápanyagokat elraktározzák, ha a sejtek növekedés gátolt valamely más tápanyag(ok) hiányában a túlélést jelentheti. A fototróf kén baktériumoknál ez a viselkedési forma nagyon gyakori, így a növekedési körülmények függvényében többféle tartalék tápanyagot képesek raktározni (elemi ként, glikogént, polihidroxi-alkánsavakat (PHA-k) és polifoszfátokat) (Dawes, 1992).

Ezen tartalék tápanyagok leggyakrabban sejten belül raktározódnak és párhuzamosan akár mindegyik jelen lehet a sejtben.

A Chromatiaceae család tagjai által raktározott elemi kén, $\mathrm{SO}_{4}{ }^{2-}$-ig történő oxidációja során hat elektron szabadul fel, így egy kiváló elektrondonor, a sejt metabolikus folyamatai számára. Sötétben anaerob körülmények között a sejtek képesek életben maradni a glikogén -mint energiaforrás- bontása során felszabaduló energiát használva, ellentétben a polihidroxi-alkánsavakkal, melyek ezen körülmények között nem bonthatóak. Fény jelenlétében, azonban ezen tartalék tápanyagok is nagyon értékes szubsztrátjai a lényeges sejt komponensek bioszintézisének, illetve a bennük raktározott redukáló erő is felhasználható (Mas és Van Gemerden, 1995).

A PHA-k raktározása során felhasznált redukálóerő, a polimerek bontása révén felszabadul és bizonyos körülmények között a hidrogenázok és nitrogenázok képesek hidrogén termelésre is felhasználni. 


\subsection{A POLIHIDROXI-ALKÁNSAVAK (PHA-K)}

\subsubsection{A PHA-K FELFEDEZÉSE, TÖRTÉNELME}

Az első PHA-t a poli-(3-hidroxi-butirátot) (PHB) vagy poli-(3-hidroxi-vajsavat) (3. ábra) az 1920-as években fedezte fel a francia Maurice Lemoigne (Lemoigne, 1926). A biopolimerek „újrafelfedezésére”

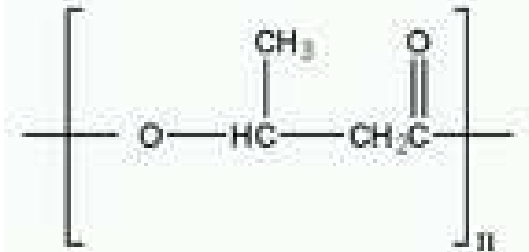

PH3B egészen 1958-1959-ig kellett várni. Ekkor jöttek rá arra is, hogy ezek a biopolimerek képesek lehetnek a máig használt petrol-kémiai alapú műanyagok kiváltására.

3. ábra. A 3-OH vajsav monomer. Legfőbb előnyük, hogy biológiai úton lebonthatóak, így a környezetet nem károsítják. Ma már több mint 160 féle hidroxi-alkánsav monomert ismerünk, melyek részt vehetnek a PHAk felépítésében (Luengo és mts., 2003).

\subsubsection{A PHA-K RAKTÁROZÁSA}

A 3-OH-zsírsav monomerekből (4. ábra). felépülő biopoliésztereket, számos baktérium képes raktározni. Bőséges $C$ forrás jelenlétében, ha a sejtek növekedése gátolt valamely fontos elem $(\mathrm{N}, \mathrm{P}, \mathrm{O}, \mathrm{S})$ hiányában, vagyis a $\mathrm{C} / \mathrm{N}, \mathrm{P}, \mathrm{O}, \mathrm{S}$ arány megnövekedett,

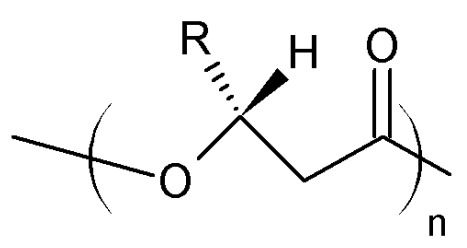

4. ábra. A PHA-k három szénatomos váza. számos mikroorganizmus polihidroxi-alkánsavakat raktároz A PHA-k felhalmozása a szén és energiaraktározás egyik gyakori formája.

Szinte mindegyik prokarióta nemzetség képviselői között találunk poliésztert raktározó fajokat, beleértve az aerob-, anaerob-, fotoszintetikus- és Ciano- illetve Archeabaktériumokat is. A PHA-k raktározására több mint 300 különböző Gram pozitív és Gram negatív mikroorganizmus (Cupriavidus necator, Bacillus spp. Pseudomonas fajok, E. coli, Alcaligenes spp., Aeromonas hydrophilia, Rhodopseudomonas palustris stb.) képes. A C. necator baktériumok a sejtek 
száraz tömegének akár 90\%-ában is képesek PHA-kat raktározni (Steinbüchel és LütkeEversloh, 2003).

A biopoliészterek számos nano méretű, vízben oldhatatlan zárvány, granulum formájában raktározódnak a sejtben. A granulumokba rendeződött poliészter ideális tartalék tápanyag, mivel kémiailag és ozmotikusan is semleges, ecetsavvá könnyen visszaalakítható, azaz könnyedén elérhető szén- és redukáló erőforrást jelent (Rehm, 2007).

A legismertebb biopolimer a polihidroxi-vajsav (PHB), amely [R]-3-hidroxi-vajsav monomerekből (3. ábra) épül fel, valójában csak az egyik tagja azoknak a természetes polimereknek, melyek 3 szénatomos vázzal rendelkező monomerekből épülnek fel (4. ábra). Ehez a vázhoz a $\beta$ vagy a 3-as pozícióban (R-el jelölt) többféle alkil csoport kapcsolódhat (1. táblázat) (a PHB esetében ez egy metil csoport), ezzel módosítva a molekula asszimetrikus centrumát. A 3-as pozícióbeli R-csoport hossza metil (C1) és tridecil (C13) között változhat. A R-csoport minősége határozza meg a molekula fiziko-kémiai tulajdonságait (pl.: olvadáspont, flexibilitás), valamint azokat az enzimeket, melyek képesek szintetizálni, illetve lebontani a polimereket (Lenz és Marchessault, 2005).

\begin{tabular}{lll}
\hline R-csoport & Teljes név & Rövidített név \\
\hline $\mathrm{CH}_{3}-$ & Poli(3-hidroxi-vajsav) & PHB \\
$\mathrm{CH}_{2}-\mathrm{CH}_{3}-$ & Poli(3-hidroxi-valeriánsav) & PHV \\
$\mathrm{CH}_{3}-\mathrm{CH}_{2}-\mathrm{CH}_{3}-$ & Poli(3-hidroxi-hexánsav) & PHHx \\
\hline
\end{tabular}

1. táblázat. Néhány PHA és a megfelelő R-csoportok.

\subsubsection{KOPOLIMEREK}

A PHA-k esetében akkor beszélünk kopolimerekről, amikor a poliészter szintáz enzim különböző típusú monomerekből építi fel a polimer láncot. Ha a mikroorganizmusoknak kevert szubsztrátot adunk, pl.: glükózt és valeriánsavat, akkor poli(3-hidroxi-vajsav-ko-3-hidroxivaleriánsav) (PHBV), vagy a poli (3-hidroxi-vajsav-ko-4-hidroxi-vajsav) (PHB4B) polimereket épít (Yan és mts., 2005). Azonban leírtak már rövid és közepes szénláncú monomereket tartalmazó kopolimereket is (pl.: PHB-co-Hx), mely 3-hidroxi-vajsavat és 3-hidroxi-hexánsav monomereket 
tartalmaz (Park és mts., 2005). Ha több szubsztrát keverékét használjuk véletlenszerü kopolimerek alakulnak ki.

(a)

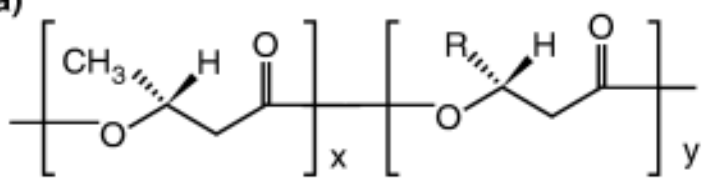

(b)

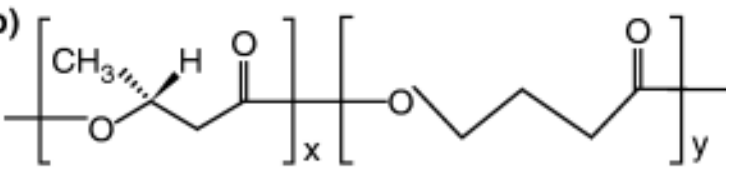

5. ábra. (a) A polihidroxi-vajsav kopolimerek általános képlete. (b)A poli (3-hidroxi-vajsav-ko-4hidroxi vajsav szerkezete (az $x$ és y a monomerek számát mutatja).

A kopolimerek kialakításában nagyon lényeges a polimerizációt katalízáló enzim (poliészter szintáz) szubsztrát specificitása, mivel ezen enzimek nagyon gyakran csak vagy rövid, vagy közepes szénláncú monomereket képesek beépíteni a növekedő polimer láncba és csak ritkán minkét típusú monomert (Rehm, 2003).

\subsubsection{A PHA-K CSOPORTOSÍTÁSA}

A polihidroxi-alkánokat legegyszerúbben az „ $R$ ” oldalláncaik hossza alapján csoportosíthatjuk. E szerint megkülönböztetünk rövid szén láncú polimereket $\left(\mathrm{PHA}_{\mathrm{rs}}\right)$, (pl. PHB, PHV). Ebben az esetben az oldallánc hosszúsága 1- 5 szén atom között váltakozik. Ha az oldallánc hossza 6 és 16 szénatom között mozog, akkor közepes szzén láncú (PHA ${ }_{\text {ssl }}$ ) PHA-ról beszélünk (Rehm, 2007).

\subsubsection{A PHA-K BIOSZINTÉZISE}

A PHB metabolizmusát a legrészletesebben C. necator-ban (korábbi elnevezés Ralstonia eutropha) tanulmányozták (Yuan és mts., 2001).

A PHB bioszintézise során az első lépésben a 3-ketotioláz (PhaA) két acetil-CoA-t egyesít aceto-acetil-CoA molekulává (6. ábra). Az acetoacetil-CoA redukcióját, NADH felhasználásával hidroxi-butiril-CoA-vá az acetoacetil-CoA reduktáz (PhaB) katalizálja.

Az utolsó lépésben a PHB szintáz (PhaC) az (R)-3-hidroxi-vajsav-CoA enantiomereket építi be a növekvő polimer láncba. A polimeráz elsősorban [R]-izomereket ismer fel szubsztrátjaként (Lenz és Marchessault, 2005) és csak nagyon ritkán [S]-izomereket (Haywood és mts., 1991).

A baktériumok normális növekedése során a 3-ketotioláz enzim múködését gátolják a citromsav ciklusból kijutó szabad CoA-SH molekulák. Abban az esetben, ha az acetil-CoA 
belépése a Krebs ciklusba gátolt - valamilyen szénen kívüli tápanyag hiánya miatt - a felgyülemlett acetil-CoA poliészter szintézisre fordítódik (Ratlege és Kristiansen, 2001).

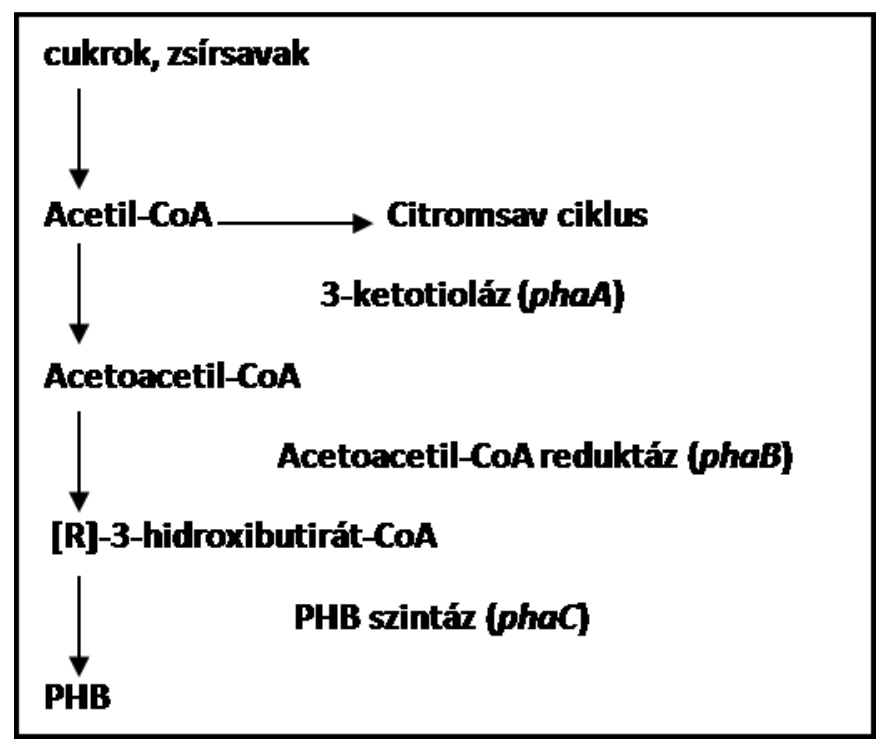

6. ábra. A PHB bioszintézise.

A mikroorganizmusok számos szubsztrátot képesek felhasználni a PHA-k szintézisére (pl.: az olcsó cukoripari melléktermékek, növényi olajok és zsírsavak, alkánok, egyszerü szénhidrátok stb.).

A közepes szénláncú (ksl) PHA-ok bioszintéziséhez három fő anyagcsereútvonal termel ksIPHA monomereket. Az első a lánc hosszabbítás, mely során az acil-CoA és a acetil CoA összekapcsolása történik, a második a zsírsavak $\beta$-oxidációja, a harmadik, pedig a zsírsavak de novo bioszintézise (Kessler és Withholt 1999). A legtöbb kclPHA-t raktározó baktériumban, a közepes szénláncú PHA-k bioszintézise a zsírsavak de novo bioszintéziséhez és/vagy a zsírsavak $\beta$-oxidációjához kapcsolt (Steinbüchel és Lütke-Eversloh 2003).

A glükóz és glükonsav jelenlétében növesztett Pseudomonas putida és Pseudomonas aerugenosa fajok olyan ksIPHA kopolimert raktároznak, mely elsősorban 2-hidroxi-dekánsav monomerekből, illetve kisebb mennyiségben egyéb közepes szénláncú 3-hidroxi-alkánsav monomerekből épül fel. Ezen baktériumok a de novo zsírsav bioszintézis útvonal köztitermékeit használják az R(-)-ksl-3-HA-CoA zsírsav monomerek szintéziséhez (Steinbüchel és Füchtenbusch, 1998) . 
Számos Pseudomonas fajnál ( $P$. oleovorans, $P$. resinovovorans), a rövid- és közepes szénláncú PHA-k együttes raktározását is megfigyelték (Doi és mts., 1995; Kang és mts., 2001).

\subsubsection{A POLIÉSZTER SZINTÁZ}

A poliészter szintázok a biopolimerek szintézisének kulcsenzimei. Az elsők között a $C$. necator az I.-es osztályú, valamint Allochromatium vinosum III.-as osztályú szintázát, írták le és jellemezték (Yuan és mts., 2001). Nem sokkal ezután egy harmadik és egy negyedik osztályba tartozó poliészter szintázt is sikerült izolálni. Ma már több mint 68 különböző baktériumban 88 különböző PHA szintáz gént ismerünk.

A PHA szintázokat szubsztrátspecificitásuk, illetve felépítésük alapján 4 osztályba soroljuk: (2. táblázat) (Rehm, 2003; Rehm, 2007):

I. és II. osztály: Ezek az enzimek csak egy alegységet tartalmaznak (PhaC), melyek molekulatömege $\left(M_{w}\right) 61$ és 73 kDa között változik. Ezen két osztály szubsztrát specificitását - in vivo és in vitro - megvizsgálva azt találták, hogy a C. necator- I-es típusú enzime a különböző (R)-3-hidroxi-zsírsavak (3-5 szén atomot tartalmazó láncok) CoA tioésztereit , míg a II.-es osztályba tartozó $P$. aeruginosa-szintáza - a 6-14 szén atomos (R)-3-hidroxi-zsírsavak CoA tioésztereit ismerik fel szubsztrátként (Rehm, 2003).

III. osztály: Ilyen szintázt találtak pl.: A. vinosumban. Ezek az enzimek két különböző alegységből épülnek fel: 1) PhaC alegység ( $M_{w}$ kb. 40 kDa). 2) PhaE alegység ( $\left.M_{w} k b .40 k D a\right)$, viszont nem hasonlít a PhaC alegységre. Ezen enzimcsalád szubsztrátjai ugyancsak a 3-5 szénatomos (R)-3-hidroxi-CoA tioészterek (Liebergessel és mts., 1992; Liebergessel és Steinbüchel, 1992). A III. osztályba tartozó, kétkomponensű PHB szintázok a YProteobaktériumok mellett (A. vinosum), a Cianobaktériumoknál is igen elterjedtek (Hai, 2001).

A. vinosum-ban a funkcionálisan aktív III-as osztályú szintáz kifejeződéséhez, mind a két alegység (PhaC és PhaE) kifejeződése szükséges. Az egyedül kifejeződő PhaE alegység inaktív, és a PhaC alegység is egyedül csak elhanyagolható aktivitást mutatott (Müh és mts., 1999). 
IV. osztály: Ilyen típusú szintáz található például a Bacillus megaterium-ban. Ezen enzim osztály, hasonló a III.-as típusú szintázokhoz azzal a különbséggel, hogy a PhaE alegységet itt a PhaR ( $M_{w}$ kb. 20 kDa) alegység helyettesíti (McCool és Cannon, 2001).

\begin{tabular}{|c|c|c|c|}
\hline Osztály & Alegység & Faj & Szubsztrát \\
\hline $\mathrm{I}$ & $\sim 60-73 \mathrm{kDa}$ & Cupriavidus necator & $\begin{array}{c}3 \mathrm{HA}_{\mathrm{SCL}}-\mathrm{CoA} \\
(\sim \mathrm{C} 3-\mathrm{C} 5) \\
4 \mathrm{HA}_{\mathrm{SCL}}-\mathrm{CoA}, \\
5 \mathrm{HA}_{\mathrm{SCL}}-\mathrm{CoA}, 3 \mathrm{MA}_{\mathrm{SCL}}-\mathrm{CoA}\end{array}$ \\
\hline II & $\underset{\sim 60-65 \mathrm{kDa}}{\text { PhaC }}$ & Pseudomonas aeruginosa & $\begin{array}{c}\text { 3HA }_{\mathrm{MCZ}-\mathrm{CoA}} \\
(\because \mathbb{C} 5)\end{array}$ \\
\hline III & $\begin{array}{l}\text { Phac PhaE } \\
\sim 40 \mathrm{kDa} \sim 40 \mathrm{kDa}\end{array}$ & Allochromatium vinosum & $\begin{array}{c}3 \mathrm{HA}_{\mathrm{SCI}}-\mathrm{CoA} \\
\left(3 \mathrm{HA} \mathrm{A}_{\mathrm{MCC}}-\mathrm{CoA}[\mathrm{C} 6-\mathrm{C} 8],\right. \\
4 \mathrm{HA}-\mathrm{COA}, 5 \mathrm{HA}-\mathrm{CoA})\end{array}$ \\
\hline IV & $\begin{array}{c}\text { Phad PhaR } \\
\sim 40 \mathrm{kDa} \sim 22 \mathrm{kDa}\end{array}$ & Bacillus megaterium & $3 \mathrm{HA}_{\mathrm{SCI}}-\mathrm{CoA}$ \\
\hline
\end{tabular}

2. táblázat. A poliészter szintázok 4 osztálya és szubsztrátjaik (Rehm, 2003).

Ezen osztályozás nem teszi lehetővé minden PHA szintáz besorolását a négy meglévő osztályba. Sajátos szintázzal rendelkezik például a Thiocystis pfennigii (korábban Thiocapsa pfennigii), melynek mindkét alegysége a III.-ik osztályba sorolt szintázok PhaC alegységéhez, vagy az Aeromonas punctata egy alegységes enzime, mely az I.-es osztály enzimjeihez mutat nagy hasonlóságot (Rehm, 2007).

Számos poliészter szintáz fehérje szekvenciáját összhasonlítva hat konzervált aminosav tömböt, illetve nyolc konzervált aminosavat sikerült azonosítani. A szekvenciák egymásra illesztése során továbbá kiderült, hogy mindegyik szintáz tartalmaz egy lipáz motívumszerű struktúrát (G-X-[S/C]-X-G), melyben a lipázokban megtalálható katalitikus szerin, a poliészter szintázokban ciszteinre cserélődik (7. ábra). A konzervált domén homológia vizsgálatok során egy $\alpha / \beta$ hidroláz domént is találtak (Jia és mts., 2000). 


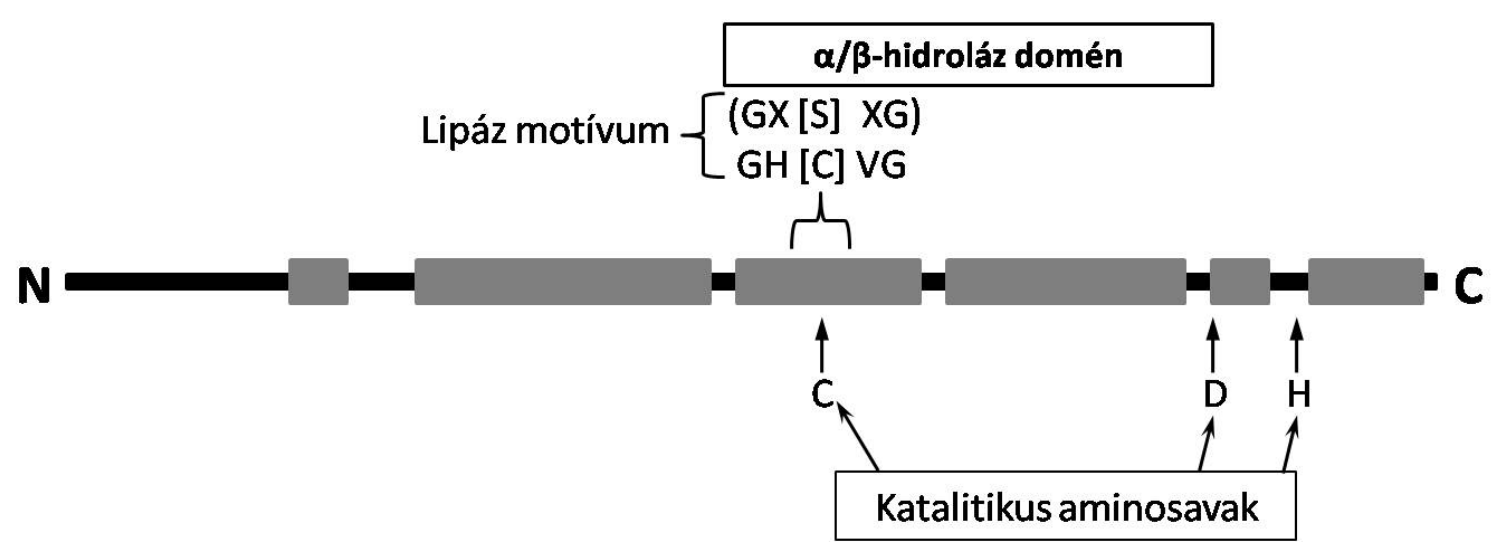

7. ábra. A C. necator poliészter szintáz elsődleges szerkezete (Rehm, 2007).

Az A. vinosum PhaC szintáz Cys-130, Cys-149, His-302, His-303, His-331 és Asp-302 aminosavainak mutációs analízise egyértelműen megmutatta, hogy a Cys-149, His-331 és Asp-302 közvetlenül az enzim katalitikus aktivitásában érintettek. Ezen aminosavak cseréje teljesen megszünteti az enzim aktivitását (Jia és mts., 2000).

\subsubsection{A POLIHIDROXI-ALKÁNSAVAK LEBONTÁSA}

A PHA-k egyik legfontosabb tulajdonsága, hogy biológiai úton lebonthatóak a poliészter depolimeráz enzimek segítségével. A PHA-kat, a természetben élő mikroorganizmusok jelentős része képes lebontani és tápanyagként felhasználni (Jendrossek és Handrick, 2002; Choi és mts., 2004). Ezen enzimek hatékonysága nagy mértékben változik a polimer összetételétől függően, valamint egyes környezeti tényezők, mint pl.: hőmérséklet, UV fény (ami segíti a lebontást) hatására (Shangguan és mts., 2006). A környezetbe kikerült PHA-k bomlása néhány hónaptól (anaerob iszap), akár egy évig is eltarthat (tengervíz) (Madison és Huisman, 1999).

A polihidroxi-vajsav bontása során a szintézisnél ismertetett folyamatok, fordított irányba mennek végbe, vagyis a poliészter láncot a depolimerázok és hidrolázok 3-HB monomerekre bontják. A 3-HB monomereket a 3-hidroxi-vajsav dehidrogenáz oxidálja, NADH képződése mellett- aceto-acetil CoA-vá. Az aceto-acetil CoA-t a tioláz enzim hasítja, mely terméke két acetil CoA molekula.

A PHA-k lebontásában extracelluláris és intracelluláris depolimerázok vesznek részt. Nagyon lényeges különbséget tenni a polimerek intracelluláris és extracellulláris lebontása 
között, mivel a PHA granulumok sejten belül és sejten kívül más-más biofizikai állapotban vannak jelen. Sejten belül a granulumokat egy foszfolipid és fehérjeburok által fedett (ún. natív ( $\mathrm{nPHA}$ ), sejten kívül egy burok nélküli, részben kristályos (a kristályosság foka általában 50-60\%-os) szemcsék (ún. denaturált (dPHA) formájában vannak jelen. A sejtek lízise vagy apoptózisa révén kikerült PHA-k az extracelluláris poliészterek forrásai. Az intracelluláris depolimerázok a natív-, az extracelluláris depolimerázok a denaturált sejten kívüli granulumokat bontják (Tokiwa és Calabia, 2004; Jendrossek és Handrick, 2002).

A poliészter depolimerázok az $\alpha / \beta$ hidrolázok családjába tartozó karboxil-észterázok (Jendrossek és Handrick, 2002).

Az extracelluláris dPHA depolimerázok a legismertebb és legalaposabban tanulmányozott poliészter bontó enzimek. Ezen enzimekre jellemző az alábbi funkcionális struktúráltság (8. ábra):

A. Egy 22-58 aminosav hosszú szignál szekvencia (szignál peptid), mely a fehérje citoplazmából való kijutásához szükséges.

B. Egy nagyméretű N-terminális katalitikus domén. A dPHA depolimerázokra jellemző három nagyon konzervált aminosav (szerin-aszpartát-hisztidin), melyek egy katalitikus centrum kialakításában vesznek részt. $\mathrm{A}$ katalitikus szerin egy szintázoknál már ismertetett lipáz motívumba (G-X-[S]-X-G) ágyazódva található meg. A dPHB depolimerázokban egy másik nem katalitikus, de úgyancsak konzervált hisztidin is megtalálható. Ezen hisztidin közelében elhelyezkedő aminosavak nagy hasonlóságot mutatnak, egy a lipázokra jellemző oxi-anion üreg motívumra (Jendrossek és Handrick, 2002). A hisztidin, mint oxi-anion aminosav és a közelében elhelyezkedő egyéb aminosavak olyan struktúrát alakítanak ki, melynek fő szerepe a hidrolízises reakció stabilizálása. Az oxi-anion üregnek, a lipáz motívumhoz viszonyított elhelyezkedése alapján, két katalitikus domént különböztetünk meg (8. ábra):

1. típusú katalitikus domén, amikor az oxi-anion üreg - a lipázokhoz hasonlóan - a lipáz motívum N-terminális régiójában helyezkedik el (hisztidin (oxi-anion)-szerin-aszpartáthisztidin).

2. típusú katalitikus domén, amikor az oxi-anion üreg a lipáz motívum C-terminális régiójában helyezkedik el (-szerin-aszpartát-hisztidin-hisztidin (oxi-anion). 
C. A katalitikus és C-terminális régiót összekapcsoló (linker), melynek szerepe nem teljesen ismert, de pl. Alcaligenes faecalis-ban a depolimeráz aktivitáshoz nélkülözhetetlen (Nojiri és Saito, 1997). Három különböző típusa ismert.

D. A 40-60 aminosav által kialakított C-terminális szubsztrát kötő doménnek a dPHA granulum megkötésében van szerepe.

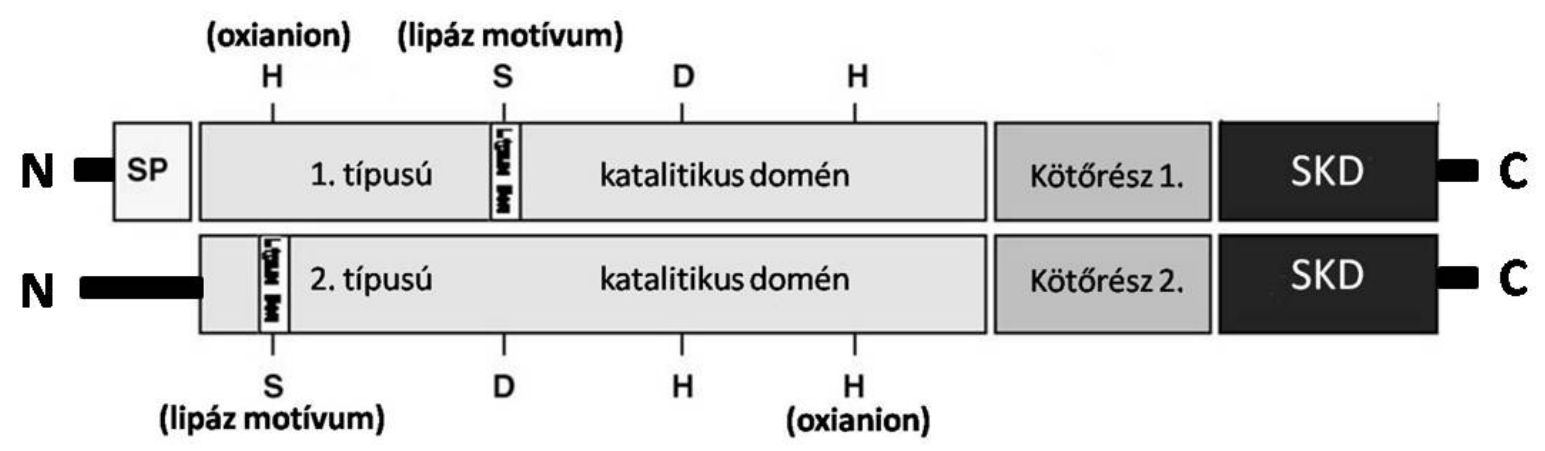

8. ábra. A dPHA $A_{R S L}$ depolimerázok szerkezete. (SP-szignál peptid; SKD-szubsztrát kötő domén) (Jendrossek és Handrick, 2002).

A PHA depolimerázokat funkciójuk és szerkezetük alapján 8 szupercsaládba sorolják (Knoll és mts., 2009):

- intracelluláris $\mathrm{nPHA}_{\mathrm{rsl}}$ depolimerázok (nem tartalmaznak lipáz motívumot),

- intracelluláris nPHA ${ }_{r s}$ depolimerázok (tartalmaznak lipáz motívumot),

- intracelluláris $\mathrm{nPHA}_{\mathrm{ks}}$ depolimerázok,

- periplazmatikus PHA depolimerázok,

- extracelluláris $\mathrm{dPHA}_{\text {rsl }}$ depolimerázok (1. típusú katalitikus domén)

- extracelluláris $\mathrm{dPHA}_{\mathrm{rsl}}$ depolimerázok (2. típusú katalitikus domén)

- extracelluláris $n P H A_{r s l}$ depolimerázok

- extracelluláris $\mathrm{dPHA}_{\mathrm{ks}}$ depolimerázok

\subsubsection{A NATÍv PHA GRANULUM SZERKEZETE}

A sejtekben raktározott polihidroxi-alkánsavak, granulumok formájában vannak jelen, egyes esetekben csaknem teljesen kitöltve a sejt teljes térfogatát. Sejtenkénti számuk általában 5-8, melyek mérete a 300 nm-től az 500 nm-ig terjedhet. A granulum felszínét egy 
foszfolipid membrán veszi körül, a membránba ágyazódott vagy a membránhoz kapcsolódó fehérjékkel (9. ábra). Ilyen fehérje a már említett poliészter szintáz (Rehm 2007), melynek az előző alfejezetben részletesen ismertetett PHA bioszintézisében van szerepe.

A membránban lokalizált a PHA depolimeráz (PhaZ) is, mely a PHA-k lebontásáért felel (Jendrossek és Handrick, 2002; Choi és mts., 2004). A membránban még megtalálhatóak a regulátor fehérje (York és mts., 2002), a fazin fehérje (Jurasek és Marchessault 2002) és egyéb, eddig még nem tisztázott funkciójú fehérjék (Phal, PhaD, PhaS) (Hoffmann és mts., 2001).

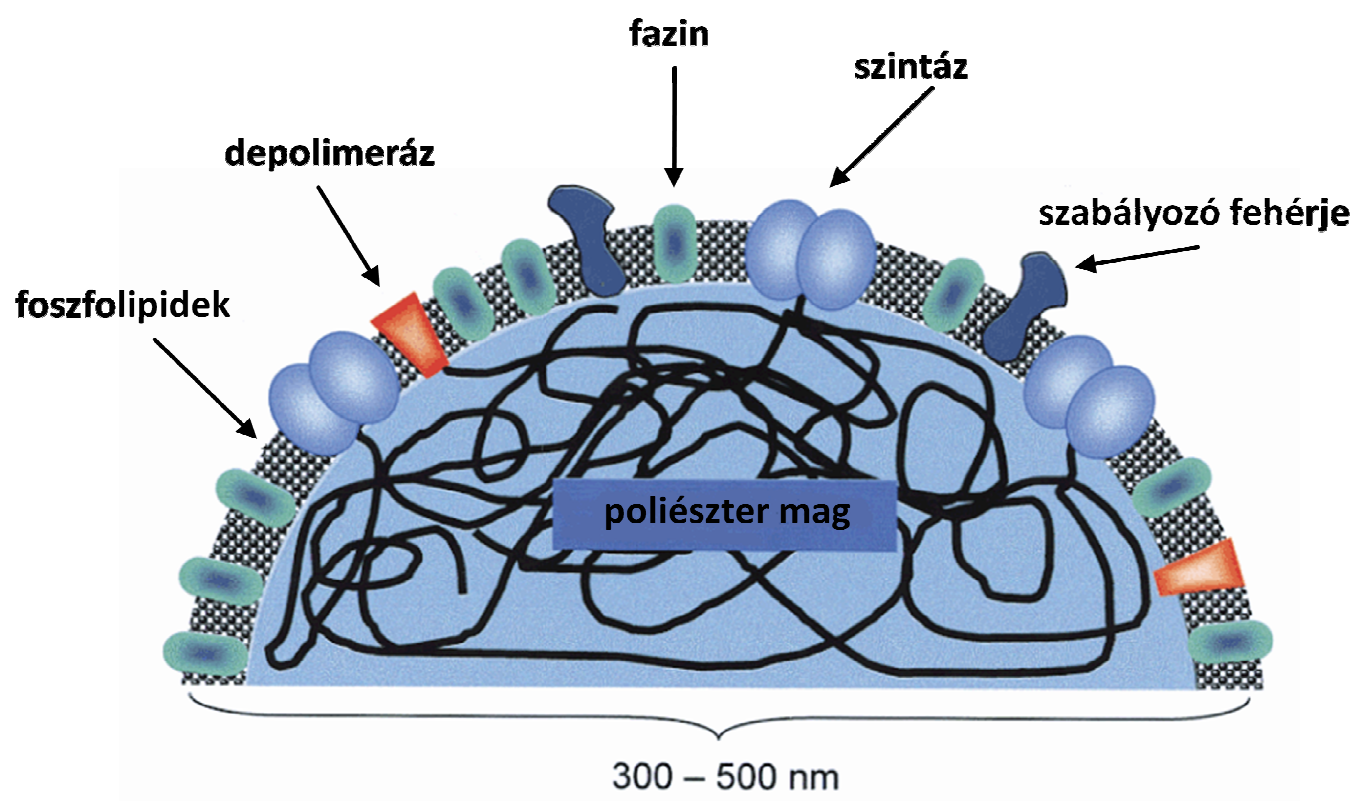

9. ábra. A poliészter granulum sematikus szerkezete

(Rehm, 2003).

Számos PHA specifikus regulátor ismert, mint pl.: a C. necator-ban és Paracoccus denitrificans-ban a PhaR (York és mts., 2002; Maehara és mts., 1999; Maehara és mts., 2002), és Pseudomonas törzsekben a PhaF (Hoffmann és Rehm, 2004), melyek - PHB jelenlététől függően - a fazin fehérjék szintézisét szabályozzák.

A fazinok (PhaP) olyan struktúrfehérjék, amelyek elősegítik a PHA-k bioszintézisét, valamint a granulum méretére is hatással lehetnek (Pötter és mts., 2004).

Pseudomonas törzsekben egyéb struktúrfehérjéket (Phal, PhaD, PhaS) is azonosítottak (Kessler és Witholt, 2001), melyeknek feltehetően a szintézisben és a granulum felépítésében van szerepe. 


\subsubsection{A PHA-K BIOLÓGIAI SZEREPE}

Számos poliésztert raktározó fajt tanulmányozva kiderült, hogy a polihidroxialkánsavaknak fontos szerepe van a bakteriális fitneszben, így egyértelmúvé vált, hogy ez a polimer több mint sejten belüli szén és energiaforrás. Amellett, hogy a PHA-nak fontos szerepe van a stressz türésben (UV besugárzás, só stressz, hő és oxidatív stressz, szárazság, illetve ozmotikus stressz (Kadouri és mts., 2005; Zhao és mts., 2007), NADH szintézisre és így ATP termelésére is felhasználható.

Az eltérő környezeti körülmények között a PHA-k bontása során felszabaduló energia számos fontos anyagcsere útvonalat képes meghajtani.

Az Azospirillum brasilense és Sinorhizobium meliloti fajokban a PHA-k bontás során felszabaduló redukáló erő energiával látja el a kemotaktikus mozgást, magyarázva, hogy a phaC mutáns törzsek miért kevésbé versenyképesek, mint a vad típusok (Kadouri és mts., 2003; Willis és Walker, 1998).

Az exopoliszacharidok (EPS) szerepét a baktériumokban természetes környezete határozza meg. Leggyakrabban védő funkciót látnak el: a nagymértékben hidratált EPS , mellyel képesek a baktériumok magukat körbevenni védőpajzsként funkcionál a kiszáradás és a ragadozók ellen (Kumar és mts., 2007). Számos mikroba termel és él egy EPS mátrixban, mely szintéziséhez a PHA-k bontása során felszabaduló energiát használják. Az A. brasilense és S. meliloti fajokban az EPS-nek még fontos szerep van a növény-mikróba kölcsönhatásban is (Kadouri és mts., 2003; Wang és mts., 2007).

Az elpusztult PHA-kat raktározó mikroorganizmusokból kijutó PHA-k a környezetben előforduló más mikroorganizmusok számára is egy könnyen elbontható szén és energiaforrást jelentenek, mivel számos alga-, gomba- és baktériumfaj képes lebontani extracellulláris PHA depolimerázok segítségével.

\subsubsection{A POLIHIDROXI-ALKÁNSAVAK IPARI ELŐÁLLÍTÁSA ÉS FELHASZNÁLÁSA}

Napjainkban a C. necator fermentációja teszi lehetővé a leggazdaságosabb PHA termelést. Azokban az esetben, ha más baktériumokat vagy mezőgazdasági növényeket használnak PHA-k termelésre, akkor is leggyakrabban a klónozás révén bejutatott $C$. necator pha géneket használják (Verlinden és mts., 2007). 
A PHBV kopolimer ipari léptékű termelését az Imperial Chemical Industries kezdte el és termelésük 2005-ben már 50.000 tonna körül mozgott évente (Lenz és Marchessault 2005) és azóta is folyamatosan növekszik.

A baktériumok fermentációs PHA termelése általában két szakaszos félfolyamatos üzemű fermentációval történik. Az első lépés során, a tápanyagban gazdag környezetben felnövesztett sejtek elég biomasszát termelnek ahhoz, hogy a második szakaszban bizonyos tápanyagok (N, S, P, O stb.) teljes megvonása jelentős poliészter raktározáshoz vezessen. (Suriyamongkol és mts., 2007).

A PHA-k felhasználás elsődleges célja a petrol-kémiai, biológiailag nem lebomló polimerek, csomagolóanyagok helyettesítése.

Elterjedtek a csomagolóanyag iparban, továbbá felhasználják személyi higiéniai cikkek gyártásánál. Megtalálhatóak festékpatronokban, ragasztószalagokban is (Philip és mts., 2007).

A PHA-k-nak számos egészségügyi alkalmazása is van, mivel beültethetőek az emberi testbe és nem szükséges onnan eltávolítani, mert a lebomlásuk során keletkező 3-hidroxivajsav természetes összetevője az emberi plazmának (Zinn és mts., 2001).

Tiszta formában vagy kompozitot alkotva a PHA-k sebek varrására, ortopéd tűskék, adhéziós gátak, csontvelő állványzatok készítésére használhatóak. A PHA-k és a hidroxi-apatit egy bioaktív és biológiailag lebomló kompozitot alkotnak, ami kiváló a csontszövet pótlására és aktívan segíti a csontszövet regenerációját is (Wu és mts., 2009).

\subsubsection{A PHA-K RAKTÁROZÁSA ÉS A HIDROGÉN METABOLIZMUS KAPCSOLATA FOTOTRÓF MIKROORGANIZMUSOKBAN}

A különböző fotoszintetizáló baktériumok jelentős mennyiségű PHB-t képesek raktározni (Brandl és mts., 1991; Liebergesell és mts., 1991; Mas és Van Gemernden, 1995). A fotoszintetizáló baktériumokban a heterotróf baktériumokhoz hasonlóan, a PHB raktározást a közeg nitrogén tartalma határozza meg (Brandl és mts., 1991). A bíbor nem kén- és kén baktériumokban ( $R$. rubrum, A. vinosum, Thiocystis violaceae, T. phenigii stb.) számos szubsztrátot kipróbálva (pl. ecetsav, propionsav, valeriánsav), az ecetsav bizonyult a legelőnyösebb szubsztrátnak a nagy mennyiségben történő PHB raktározásakor (Brandl és 
mts., 1991, Liebergesell és mts., 1991). A Rhodobacter sphaeroides RV sejteknél több szerves savat (ecetsav, tejsav, borostyánkősav, piroszőlősav, glükóz) teszteltek, de ugyancsak az ecetsav tette lehetővé a legnagyobb mértékű PHB raktározást (Khatipov és mts., 1998).

A R. palustris (De Philippis és mts., 1992), a R. sphaeroides és a R. rubrum (Hustede és mts., 1993) törzseknél azt találták, hogy ecetsav jelenlétében a hidrogén termelés és a PHB raktározás között "versengés" folyik a redukáló erőért, tehát egy időben a két folyamat nem lehetséges.

A Rhodovulum sulfidophilum sejtek, azonos megvilágítási körülmények között, a PHB$\mathrm{t}$ kissé hatékonyabban használják fel hidrogén termelésre, mint a borostyánkősavat, mely az egyik legjobb hidrogén termelő külső szubsztrátnak bizonyult (Maeda és mts., 2002). Ezekben a sejtekben a raktározott PHB - külső szubsztrát hiányában - hidrogén termelésre felhasználható (Maeda és mts., 1997).

\subsection{THIOCAPSA ROSEOPERSICINA BBS}

A Thiocapsa roseopersicina egy Gram-negatív anaerob fotoszintetizáló bíbor kén $\gamma$ Proteobaktérium, a Chromatiaceae család tagja, mely mikroszkópban nem mozgékony 1-3 um-es kokkuszként figyelhető meg (Gogotov és mts., 1976; Pfennig és Trüpper, 1991). A kénbaktériumok elsősorban redukált kénvegyületeket (tioszulfát, szulfid, elemi kén stb.) használnak elektrondonorként, de egyszerű szerves szubsztrátok (pl.: ecetsav, piroszőlősav, tejsav) és a molekuláris hidrogén is elláthatja ezt a feladatot (Sasikala és mts., 1993). A sejtek belső, fotoszintetikus membrán betüremkedéseket tartalmaznak. Sötétben, aerob kemolitotróf növekedésre képesek (Kondratieva és mts., 1976). Kötött nitrogénforrás hiányában, [Mo-Fe] típusú nitrogenáz enzimrendszere segítségével a légköri nitrogén megkötésére is képes (Bogorov, 1974), miközben melléktermékként $\mathrm{H}_{2}$ képződik.

Az eredetileg a Jeges-tengerből izolált BBS nevű törzsnek az optimális növekedési hőmérséklete $24-28^{\circ} \mathrm{C}, 30^{\circ} \mathrm{C}$ felett a növekedése gátolt (Bogorov, 1974). Folyadékban 4-6 nap alatt éri el a stacioner növekedési fázist, táplemezen 10-14 nap alatt képez látható telepeket. A T. roseopersicina, számos fototróf baktériumhoz hasonlóan, növekedési körülményeitől függően képes ként, glikogént, polihidroxi-alkánokat és polifoszfátokat raktározni (Dawes, 1992). A fototróf bíbor kénbaktériumokban a leggyakrabban raktározott 
polihidroxi-alkánsav a PHB, habár $A$. vinosum-ban PHBV kopolimer raktározását figyelték meg (Liebergesell és mts., 1991).

\subsubsection{A THIOCAPSA ROSEOPERSICINA HIDROGENÁZAI}

A T. roseopersicina azon mikroorganizmusok egyike, amelyben számos hidrogenázt sikerült azonosítani. A T. roseopersicina öt különböző típusú [NiFe] hidrogenáz enzimet tartalmaz (10. ábra): Hup (Colbeau és mts., 1994,), Hyn (Rákhely és mts., 1998; Kovács és mts., 2002), Hox1 (Rákhely és mts., 2004), Hox2 (Maróti és mts., 2010), valamint egy regulátor hidrogenáz kódoló operont, melynek génjeiről (hupTUV) nem képződik aktív fehérje (Kovács és mts., 2005/A). A Hup és a Hyn membránhoz kötött, míg a Hox1 és a Hox2 citoplazmatikus elhelyezkedésű hidrogenáz (10. ábra).

A különböző hidrogenázok felépítésében, érésében szerepet játszó számos fehérje génjei a genomban szétszórva helyezkednek el (Kovács és mts., 2005/B).

\subsubsection{A MEMBRÁN KÖTÖTT HIDROGENÁZOK}

T. roseopersicina-ban a membrán kötött hidrogenázok a hydrogen uptake (hidrogén visszavétel) Ni-Fe hidrogenázok csoportjába (Vignais és mts., 2001) tartoznak.

A Hup hidrogenáz (hupSL) legfőbb funkciója a nitrogenáz által termelt hidrogén visszavétele, a nitrogén fixáló körülmények között növesztett sejtekben.

A Hyn hidrogenáz (hynSL) (régebben Hyd (Rákhely és mts., 1998)) a másik membránkötött hidrogenáz, mely extrém stabilitást mutat hővel, oxigénnel és proteázokkal szemben (Kovács és mts., 1988; Gogotov és mts., 1976), valamint a fotoszintetikus membránból eltávolítva is aktív marad (Kovács és Bagyinka, 1990). Nagyfokú stabilitása miatt a Hyn enzim ideális alanya lehet a biotechnológiai hasznosításoknak.

\subsubsection{A CITOPLAZMATIKUS HIDROGENÁZOK}

A harmadik ismert hidrogenáz a Hox1 hidrogenáz mely a hox1EFUYH operonban kódolt. Az enzim a citoplazmatikus $\mathrm{NAD}^{+}$redukáló cianobakteriális [NiFe] hidrogenázok közé tartozik (Rákhely és mts., 2004). Az enzim öt alegységből épül fel, amelyek közül a Hox1YH a 
hidrogenáz részt, a Hox1FU egy diaforázt, valamint a diaforázhoz kapcsolódó és feltehetően az elektron transzportban szerepet játszó Hox1E alegység építi fel (Palágyi-Mészáros és mts., 2009). A Hox1 egy igazi kétirányú hidrogenáz, mely képes katalizálni mind a hidrogén oxidációját, mind a protonok redukcióját a sejt redox állapotának függvényében. A Hox1 hidrogenáz a legjobb hidrogén termelő enzim, melyet min a kén oxidációja során felszabaduló elektronok (Rákhely és mts., 2007), mint a glikogén bontásából származó elektronok képesek meghajtani (Béres és mts., személyes közlemény).

A nemrég leírt Hox2 hidrogenáz is a $\mathrm{NAD}^{+}$redukáló hidrogenázok csoportjába tartozik. Ez a négy alegységes hidrogenáz a Hox1-hez hasonló struktúrát mutat (hidrogenáz rész $(h o x 2 H$,$) diaforáz rész (hox2UF)). A Hox2 egy meglehetősen alacsony expressziós szintű$ és aktivitású enzim, mely a sejt egy kései, stacioner fázisba történő átmenetkor kapcsol be és aktivítása a glükóz metabolizmushoz kapcsolható (Maróti és mts., 2010).

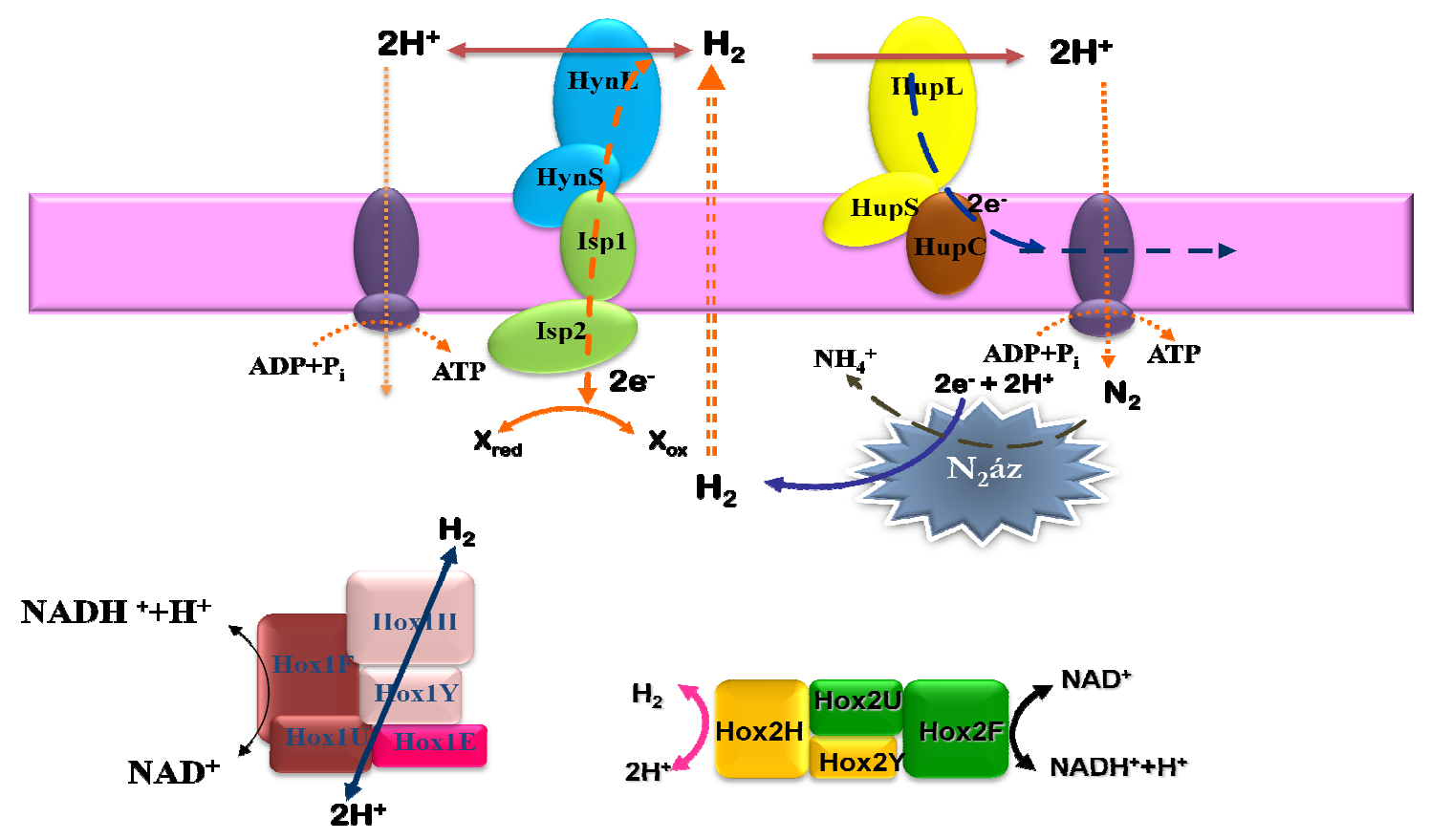

10. ábra. A T. roseopersicina BBS hidrogenázai. 


\section{CÉLKITÜZÉSEK}

A Thiocapsa roseopersicina metabolikus sokszínúsége lehetővé teszi, hogy számos szubsztrátot felhasználjon elektron igényének fedezésére. Nem kiegyensúlyozott növekedési körülmények között, a bőséges szénforrás jelenlétében, amikor a növekedés gátolt valamely fontos tápanyag csökkent mennyisége vagy hiánya miatt, a sejtek tartalék tápanyagokat raktároznak (elemi kén, glikogén, polihidroxi-alkánsavakat, polifoszfátokat). A raktározott tápanyagok, így a PHA-k is a sejtek számára könnyen elérhető szén és redukáló erő forrást jelentenek, melyek megfelelő körülmények között akár $\mathrm{H}_{2}$ termelésre is felhasználhatóak. Munkám során olyan nitrogén limitált körülményeket alkalmaztam, ahol a nitrogenáz, ATP függő hidrogenázként múködik, így hidrogént termel. Ilyen körülmények között a hidrogenázok a hidrogén oxidációját katalizálják, ezért kísérleteimhez egy aktív hidrogenázokat nem tartalmazó T. roseopersicina törzset (DC12B) választottam. Munkám során legfőbb célom volt, hogy:

- megtaláljam, a poliészter raktározásához optimális szénforrást és körülményeket

- a $T$. roseopersicina-ban azonosítsam a polihidroxi-alkánok szintézisében és lebontásban részt vevő géneket.

- megvizsgáljam a polihidroxi-alkánok szerepét a nitrogenáz katalizálta hidrogén termelésben.

- valamint megnézzem a külső elektrondonorok (tioszulfát és/vagy borostyánkősav) hatását a hidrogén termelésre a poliészterek jelenlétében/vagy hiányában. 


\section{ANYAGOK ÉS MÓDSZEREK}

\subsection{BAKTÉRIUM TÖRZSEK ÉS PLAZMIDOK}

\subsubsection{E. COLITÖRZSEK}

$\begin{array}{lll}\text { XL-1 Blue MRF' } & \text { recA1 gyrA96 }\left(F^{\prime} l a c l^{q} Z\right) T c^{r} & \text { Stratagene } \\ \text { S17-1 } \lambda \text { pir } & 294 \text { (recA pro res mod) } T p^{r} S^{r} \text { (pRP4-2-Tc::Mu-Km::Tn7) } & \text { Herrero és } \\ & & \text { mts., } 1990\end{array}$

\subsubsection{T. ROSEOPERSICINA TÖRZSEK}

\begin{tabular}{lll}
\hline DC12B & hypC $_{1} \Delta$, hypC $_{2} \Delta$, & Maróti és mts., 2003 \\
PH12B & phbBPRAEC $\triangle, D C 12 B$ & ez a munka \\
\hline
\end{tabular}

\subsubsection{PlazMidoK}

\begin{tabular}{|c|c|c|}
\hline pBluescript SK +/- & ColE1 Amp ${ }^{r}$ & Stratagene \\
\hline pK18mobSacB & $\begin{array}{l}\text { ColE1, sacB, } \mathrm{Km}^{\mathrm{r}} \text { szúk } \\
\text { gazdasepcifitású integrálódó vector }\end{array}$ & Schafer és mts., 1994 \\
\hline pPHA2_1 & $\begin{array}{l}\text { 5'-homológ régió( PHDo1- PHDo2) a } \\
\text { pK18mobsacB, Km }{ }^{r} \text { vektorban }\end{array}$ & ez a munka \\
\hline pPHA2_2 & $\begin{array}{l}\text { 5'- és 3'-(PHDo7- PHDo8) homológ régió } \\
\text { pK18mobsacB, Km }{ }^{r} \text { vektorban }\end{array}$ & ez a munka \\
\hline
\end{tabular}

\subsection{BAKTÉRIUMOK TENYÉSZTÉSE}

\subsubsection{AZ E. COLINÖVESZTÉSI KÖRÜLMÉNYEI}

Az E. coli sejteket $37^{\circ} \mathrm{C}$-on LB folyadékban vagy LB lemezen ( $\mathrm{LB}+1,5 \%$ agar) tartottam fenn. Az E. coli tenyésztésénél használt antibiotikumok és koncentrációjuk ( $\mu \mathrm{g} / \mathrm{ml})$ : lemezen és folyadékban egyaránt kanamicin: 25, ampicillin: 100 .

Az E. coli sejtek növesztéséhez használt tápoldatok: 
LB: $10 \mathrm{~g}$ tripton, $5 \mathrm{~g}$ élesztő kivonat, $10 \mathrm{~g} \mathrm{NaCl}$, desztilált vízzel $1000 \mathrm{ml}$ végtérfogatra kiegészitve.

SOB: $20 \mathrm{~g}$ tripton, $5 \mathrm{~g}$ élesztő kivonat, $0,5 \mathrm{~g} \mathrm{NaCl}$, desztilált vízzel $1000 \mathrm{ml}$ végtérfogatra kiegészitve.

\subsubsection{A T.ROSEOPERSICINA NÖVESZTÉSI KÖRÜLMÉNYEI}

A T. roseopersicina törzset $25-28^{\circ} \mathrm{C}$-on folyamatos megvilágítás mellett, teletöltött csiszolt dugós üvegekben, Pfennig féle tápoldatban növesztettem 3-4 napig (Pfennig és Trüper, 1991). A sejtek szélesztéséhez Phytagel (Sigma) tartalmú (7 g/liter) lemezeket használtam, majd a lemezeket az Oxoid AnareoGen $\left(\mathrm{N}_{2}, \mathrm{CO}_{2}\right)$ rendszereivel anaerobizált dobozokban 14 napig fényen inkubáltam.

Nitrogén fixáló körülmények biztositása cáljából a módosított Pfennig féle tápoldat nem tartalmazott $\mathrm{NH}_{4} \mathrm{Cl}$-t, míg a kultúrák légterét $\mathrm{N}_{2}$ gázzal anaerobizáltam. A $T$. roseopersicina tenyésztésénél használt antibiotikum és koncentrációja $(\mu \mathrm{g} / \mathrm{ml})$ : kanamicin: 25.

Az T. roseopersicina sejtek növesztéséhez használt tápoldatok:

PC (Pfennig-féle tápoldat): $20 \mathrm{~g} \mathrm{NaCl}, 1 \mathrm{~g} \mathrm{KH}_{2} \mathrm{PO}_{4}, 1 \mathrm{~g} \mathrm{MgCl}, 1 \mathrm{~g} \mathrm{KCl}, 1 \mathrm{~g} \mathrm{NH} 4 \mathrm{Cl}, 2 \mathrm{~g} \mathrm{NaHCO}$, 2 $\mathrm{g} \mathrm{Na} \mathrm{S}_{2} \mathrm{O}_{3}, 20 \mu \mathrm{B}_{12}$ vitamin $(100 \mathrm{mg} / \mathrm{ml}), 1 \mathrm{ml} 20 \mathrm{mM}$ Fe-EDTA, $1 \mathrm{ml}$ mikroelem oldat, desztillált vízzel 1000 ml végtérfogatra kiegészítve (Pfennig és Trüpper, 1991).

PR tápoldat: $20 \mathrm{~g} \mathrm{NaCl}, 1 \mathrm{~g} \mathrm{KH}_{2} \mathrm{PO}_{4}, 1 \mathrm{~g} \mathrm{MgCl}_{2}, 1 \mathrm{~g} \mathrm{KCl}, 0,17 \mathrm{~g}$ Na-glutamát, $2 \mathrm{~g} \mathrm{NaHCO}$, $2 \mathrm{~g}$ $\mathrm{Na}_{2} \mathrm{~S}_{2} \mathrm{O}_{3}, 10 \mathrm{~g}$ Na-ecetsav, $20 \mu \mathrm{l} \mathrm{B}_{12}$ vitamin $(100 \mu \mathrm{g} / \mathrm{ml}), 1 \mathrm{ml}$ Fe-EDTA $(3,3 \mathrm{~g} / \mathrm{l}), 1 \mathrm{ml}$ mikroelem oldat) desztillált vízzel $1000 \mathrm{ml}$ végtérfogatra kiegészítve.

HT tápoldat: $20 \mathrm{~g} \mathrm{NaCl}, 1 \mathrm{~g} \mathrm{KH}_{2} \mathrm{PO}_{4}, 1 \mathrm{~g} \mathrm{MgCl}, 1 \mathrm{~g} \mathrm{KCl}, 20 \mu \mathrm{B}_{12}$ vitamin $(100 \mu \mathrm{g} / \mathrm{ml}), 1 \mathrm{ml} \mathrm{Fe}-$ $\operatorname{EDTA}(3,3 \mathrm{~g} / \mathrm{l}), 1 \mathrm{ml}$ mikroelem oldat, desztillált vízzel $1000 \mathrm{ml}$ végtérfogatra kiegészítve; $\mathrm{pH}=7$. 
Egyes esetekben a tápoldatot $2 \mathrm{~g} \mathrm{I}^{-1}$ tioszulfáttal vagy/és $5 \mathrm{~g} \mathrm{I}^{-1}$ borostyánkősavval egészítettem ki. Ezt minden esetben a dolgozatomban a megfelelő helyeken jelöltem.

NC (nitrogénfixáló tápoldat): $20 \mathrm{~g} \mathrm{NaCl}, 1 \mathrm{~g} \mathrm{KH}_{2} \mathrm{PO}_{4}, 1 \mathrm{~g} \mathrm{MgCl}, 1 \mathrm{~g} \mathrm{KCl}, 2 \mathrm{~g} \mathrm{NaHCO}_{3}, 2 \mathrm{~g}$ $\mathrm{Na}_{2} \mathrm{~S}_{2} \mathrm{O}_{3}, 20 \mu \mathrm{l} \mathrm{B} \mathrm{B}_{12}$ vitamin $(100 \mathrm{mg} / \mathrm{ml}), 1 \mathrm{ml} 20 \mathrm{mM}$ Fe-EDTA, $1 \mathrm{ml}$ mikroelem oldat, desztillált vízzel $1000 \mathrm{ml}$ végtérfogatra kiegészítve.

Mikroelem oldat: 2975 mg Na2-EDTA, 300 mg H $\mathrm{BO}_{4}, 200 \mathrm{mg} \mathrm{CaCl} 2.6 \mathrm{H}_{2} \mathrm{O}, 100 \mathrm{mg} \mathrm{ZnSO} \mathrm{Z}_{4} 7$ $\mathrm{H}_{2} \mathrm{O}$, 30mg MnCl $.4 \mathrm{H}_{2} \mathrm{O}, 30 \mathrm{mg} \mathrm{Na} \mathrm{MoO}_{4} .2 \mathrm{H}_{2} \mathrm{O}, 20 \mathrm{mg} \mathrm{NiCl} .6 \mathrm{H}_{2} \mathrm{O}, 10 \mathrm{mg} \mathrm{CuCl} .2 \mathrm{H}_{2} \mathrm{O}$, desztillált vízzel $1000 \mathrm{ml}$ végtérfogatra kiegészítve.

A PHA-k-ból történő hidrogén termelés vizsgálatához, kétszakaszos növesztési eljárást használtam.

\subsubsection{A PHA-K RAKTÁROZÁSI SZAKASZ}

A PHA-k raktározásához a baktériumokat (400 ml sejtkultúra) 500 ml-es hipovial üvegekbe, PR tápoldatba oltottam le, majd a kultúrák légterét, 10 percig argon gázzal anaerobizáltam. Ezt követően a sejteket $25^{\circ} \mathrm{C}$-on növesztettem, folyamatos megvilágítás mellett (58 $\mu \mathrm{m} \mathrm{s}^{-1} \mathrm{~m}^{-2}$ foton fluxus intenzitás).

\subsubsection{A HIDROGÉN TERMELÉSI SZAKASZ}

5 nap elteltével, a növekedési fázis exponenciális szakaszában - anaerob körülmények mellett - PR tápoldatot a kultúra centrifugálása után eltávolítottam és a sejteket $60-60 \mathrm{ml}$ szén és nitrogén forrást nem tartalmazó HT tápoldatban vettem fel. A kultúrák $(60 \mathrm{ml}) 600$ nm-en mért abszorbanciáját 0,8-0,9- $\mathrm{cm}^{-1}$-re állítottam be, majd a lezárt üvegek gázterét 10 percig Ar gázzal anaerobizáltam. Ezt követően a sejteket $25^{\circ} \mathrm{C}$-on, az előzőekben ismertetett megvilágítási körülmények mellett tartottam. 


\subsection{DNS MANIPULÁCIÓK}

\subsubsection{GENOMI DNS IZOLÁLÁS T. ROSEOPERSICINA-BÓL}

A genomi DNS tisztításához a "Gene Elute" (Sigma) genomi DNS tisztító csomagját (kit) használtam (KT2110-KT1), a gyártó utasításainak megfelelően.

\subsubsection{Plazmid DNS TISZTÍtÁsa E. COLI-BÓL}

A plazmid DNS-t, a megfelelő antibiotikumot tartalmazó, LB tápoldatban felnőtt sejttenyészetekből (3-8 ml) tisztítottam, alkalikus lízis módszerrel (Sambrook és mts., 1989), illetve a Qiagen/Sigma/Eppendorf plazmid tisztítási csomagot használva.

\subsubsection{AgaróZ gÉLELEKTROFORÉZIS}

$A z$ analitikai és preparatív célokból végzett gélelektroforézis agaróz gélben, TAE puffer rendszerben (0,04 M Tris-ecetsav, 0,001 M EDTA, $\mathrm{pH}=8,0)$ történt, az irodalomban leírtaknak megfelelően (Ausubel és mts., 1996).

\subsubsection{DNS FRAGMENT IZOLÁLÁSA AGARÓZ GÉLBŐL}

Az agaróz gélelektroforézist követően a kívánt DNS fragmentumokat a Fermentas DNS extrakciós csomag segítségével (Fermentas, Kat. szám: KO513) izoláltam.

\subsubsection{DNS MANIPULÁCIÓK}

A DNS molekulák helyspecifikus hasítása restrikciós endonukleázokkal, az 5' vagy 3' DNS ragadós vég tompítása T4 DNS polimerázzal vagy Klenow polimerázzal történt. Az 5’ vég foszforilálása polinukleotid kinázzal, a DNS végi foszfátcsoport eltávolítása borjú bél alkalikus foszfatázzal (CIAP), a DNS molekulák ligálása T4 ligázzal történt, az enzimeket gyártó cégek (Fermentas, Stratagene, Amersham, Biosciences) utasításainak megfelelően. 


\subsubsection{KÉMIAI KOMPETENS SEJT KÉSZÍTÉS ÉS TRANSZFORMÁCIÓ}

Az E. coli kompetens sejtek készítése és a transzformáció a SEM (ㅁimple and Éfficient Method) módszer szerint történt (Inoue és mts., 1990).

\subsubsection{POLIMERÁZ LÁNCREAKCIÓ}

A polimeráz láncreakciókat PCRExpress thermocycler (Hybaid) vagy Eppendorf 5415R készülékben hajtottam végre. A reakcióelegyekben (20-50 $\mu$ l végtérfogat) alkalmazott végkoncentrációk a következőek voltak: primerek $1 \mu \mathrm{M}$, dNTP $200 \mu \mathrm{M}$, DNS polimeráz, puffer és $\mathrm{Mg}^{2+}$ : a felhasznált polimerázt gyártó cég (Phusion (Fermentas) és DyNAZyme (Finnzymes)) utasításainak megfelelően.

\subsubsection{NUKLEOTID SORREND MEGHATÁROZÁSA}

A DNS szekvencia meghatározások automata szekvenátorral (Applied Biosystem) készültek. A megfelelő klónok nukleotid sorrendjének meghatározására a pBluescriptSK+, a plazmidok szekvenáló oligonukleotidjait, illetve a specifikus oligonukleotidokat használtam.

\subsection{A PHA GÉNEK AZONOSÍTÁSA T. ROSEOPERSICINA-BAN}

A T. roseopersicina PHA-k metabolizmusában részt vevő gének azonosítására, az $A$. vinosum phaC génjét használtam TBLAST kereső szekvenciaként, a $T$. roseopersicina helyi génbankban. A T. roseopersicina PHA szintázát kódoló régió azonosítása után, 3'- és 5'irányban számos nyitott leolvasási keretet sikerült in silico azonosítanom, melyek termékei feltehetően a PHA-k metabolizmusában vesznek részt.

\subsection{A PHA DELÉCIÓS MUTÁNS LÉTREHOZÁSA}

A PHA deléciós vektorkonstrukciók elkészítéséhez egy szűk gazdaspecificitású “öngyilkos" vektort, a pK18mobsac-ot (Shafer és mts., 1994) használtam. A pha lókusz 5' homológ régióját PHADo1 (5`- TCCTGCGCCGCTTACGTCTT-3`) és PHADo2 (5`CATCGCTGCCGACGTGTCTT-3`) primerekkel felsokszoroztam. A kapott 1069 bp-os PCR 
terméket a Smal restrikciós enzimmel hasított pK18mobsacB plazmidba jutattam be (pPHA2_1). A 3' homológ régió felsokszorozása a PHADo7 (5`- CGGCAGCAAAGACTATACCG 3') és a PHADo8 (5`- TCATCACCGACGACAACTTC -3`) primerekkel történt. Az 1162 bp-os darabot az Xbal restrikciós enzimmel hasított pPHA2_1 plazmidba jutattam, így létrehozva a pPHA2_2 plazmidot. A kész plazmidot E. coli S17-1 ( $\lambda$ pir) törzsbe transzformáltam, majd a DC12B (Maróti és mts., 2003) aktív hidrogenázt nem tartalmazó T. roseopersicina törzsbe konjugációval jutattam be. Az egyszeres és kétszeres rekombinánsokat kanamicin és a sacB pozitív szelekciós rendszer (Shaffer és mts., 1994) segítségével azonosítottam.

A deléció sikerességét a PHBMo5 (5`- CCGGCACAGTTGATGAGGAT -3`) és PHBMo6 (5'TTCCATGTCAGCGGCTCCTT -3') primerekkel kapott PCR termékek mérete (mutáns 1385 bp, vad 6636 bp), továbbá szekvencia analízise is megerősítette. A pha bioszintetikus lókuszt nem tartalmazó törzset PH12B-nek neveztem el.

\subsection{FIZIOLÓGIAI MÉRÉSEK}

\subsubsection{A HIDROGÉN MENNYISÉG MÉRÉSE}

A hidrogén termelés mérését az előzményekben ismertetett HT tápoldatban (egyes esetekben $2 \mathrm{~g} \mathrm{I}^{-1}$ tioszulfáttal vagy/és $5 \mathrm{~g} \mathrm{l}^{-1}$ borostyánkősav kiegészített) végeztem. A hidrogén termelés követéséhez a kultúrák $(60 \mathrm{ml})$ légteréből 24 óránként $200 \mu \mathrm{l}$ gázt injektáltam gázkromatográfba (Agilent 6890 gázkromatográf, Molecular Sieve $5 \AA ̊$ kolonna, TCD detektor). Vivőgázként argont használtam.

\subsubsection{A PHB MENNYISÉG MEGHATÁROZÁSA}

A PHB méréshez a kissé módosított Braunegg féle savas metanolízis eljárást használtam (Braunegg és mts., 1978). A liofilizált sejtekhez (60 ml) $2 \mathrm{ml}$ 10\%-os kénsavat tartalmazó metanolt, valamint belső standardnak benzoesavat $\left(0,5 \mathrm{~g} \mathrm{I}^{-1}\right)$ adtam. Az elegyet 10 ml-es, teflon kupakkal lezárt hipovial üvegekben 4 órán át inkubáltam $100{ }^{\circ} \mathrm{C}$-os hőmérsékleten. A észterifikálási reakció során a mintákat, óránként egyszer két percig vortexeltem. Az inkubálás végeztével ioncserélt vizet $(1 \mathrm{ml})$ adtam a mintákhoz, majd 
kloroformos $(1 \mathrm{ml})$ extrakciót végeztem. Újabb 2 perces kevertetést követően, a PHB mennyiségének meghatározása a szerves fázisból történt.

A PHB meghatározására egy standard gázkromatográfiás módszert használtam (Betancourt és mts., 2007). Az előzetesen észterifikát minta szerves fázisából $1 \mu \mathrm{l}-\mathrm{t}$ fecskendeztem a gázkromatográfba (Agilent 6890 GC, Equity-1, FID). A kloroformmal higított metil-3-OH-vajsav kalibrációs egyenes lineárisan változott a 0-3 $\mathrm{ng} \mu \mathrm{l}^{-1}$ metil-3-OH vajsavat tartalmazó minták esetében.

\subsubsection{A BOROSTYÁNKŐSAV MENNYISÉG MÉRÉSE}

A borostyánkősav mennyiség mérését az előzményekben ismertetett HT tápoldatban $\left(2 \mathrm{gl}^{-1}\right.$ tioszulfáttal vagy/és $5 \mathrm{~g} \mathrm{I}^{-1}$ borostyánkősav kiegészített) nevelt kultúrákon végeztem. $\mathrm{A}$ sejtkultúrákból (60 ml) alkalmanként (48 óra) $500 \mu \mathrm{l}$ sejtet centrifugáltam le. Az így előkészített felülúszóból $50 \mu \mathrm{ll}$-t használtam a HPLC-vel (Elite LaChrom, Hitachi, ICsep ICECOREGAL 64H, RI detektor) történő borostyánkősav meghatározására. A borostyánkősav kalibrációs egyenes lineárisan változott, a 0-7 $\mathrm{g}^{-1} \mathrm{~s}$ borostyánkősavat tartalmazó tápoldat esetében.

\subsubsection{A NITROgENÁZ AKTIVITÁs MÉRÉSE}

A nitrogenáz aktivitás mérésekhez az acetilén reduciós módszert (Stewart és mts., 1967) használtam. A méréseket HT tápoldatban (egyes esetekben $2 \mathrm{~g} \mathrm{I}^{-1}$ tioszulfáttal vagy/és $5 \mathrm{~g}^{-1}$ borostyánkősav kiegészített)) tartalmazó sejtkultúrán végeztem. A $30 \mathrm{ml}$ sejtet tartalmazó hipovial üvegeket $(60 \mathrm{ml})$ argonnal anaerobizáltam, majd a kultúrák légterébe acetilén (a gáz fázis $\mathrm{kb}$. 13\%-a) és nitrogén gázt (a gáz fázis $\mathrm{kb} 3 \%$-a) jutattam. A fényen történő inkubációt (4 óra) követően, a hipovial üveg gázteréből $500 \mu$ l gázt fecskendeztem a gázktomatográfba. Az acetilén és etilén különválasztását és mennyiségi analízisét Shimadzu GC-2010 típusú gázkromatográfon végeztem (HP-PlotQ, TCD detektor). 


\subsubsection{A TiOSZULFÁt TARTALOM MEGHATÁROZÁSA}

A minta előkészítés során $500 \mu \mathrm{l}$-t vettem ki a HT tápon növesztett kultúrából (60 ml). A sejtek lefugálása után a felülúszó tioszulfát tartalma egyértelműen meghatározható volt a minták $230 \mathrm{~nm}$ UV elnyelése alapján, kvarcküvettát használva. A tioszulfát kalibrációs egyenes lineárisan változott a 0 - $3 \mathrm{~g} \mathrm{I}^{-1}$ tioszulfátot tartalmazó tápoldat jelenlétében (Maróti és mts., 2010).

\subsection{BIOINFORMATIKAI MÓDSZEREK}

A DNS és fehérje szekvenciák összehasonlítása, valamint a GenBank, Prosite és SwissProt adatbázisokban való keresések, a BLAST ( $\mathrm{X}, \mathrm{P})$ programmal történtek (www.ncbi.nih.nlm.gov/BLAST). Több fehérje aminosav sorrendjének együttes összevetésére a T-COFFEE program segítségével végeztem (Notredame és mts., 2000). A töbszörös illesztés eredményeit phylip formátumba mentettem el és ezt használtam a PhyML (http://www.atgc-montpellier.fr/phyml/; (Guindon és mts., 2010)) törzsfa elkészítéséhez, ahol az LG helyettesítési modellt és az SH szerú módszert használtam, hogy felbecsüljem az adatok helyességét a törzsfa belső elágazásainál.

A filogenetikai fákat a Figtree v1.3.1. programmal (http://tree.bio.ed.ac.uk/software/figtree/) jelenítettem meg.

\subsection{A SZEKVENCIÁK ELHELYEZÉSE AZ ADATBÁZISBAN}

A Thiocapsa roseoprsicina phaARPBCE és phaZ lókuszok szekvenciája a JN244736 és a JN244737 hivatkozási szám alatt érhető el, a GenBank adatbázisban.

\subsection{A FEHÉRJE MENNYISÉG MÉRÉSE}

A fehérje mennyiség meghatározását a Non Interfering Protein Assay ${ }^{\circledR}$ (Calbiochem; katalógus szám: 844250) csomaggal végeztem a gyártó által leírt utasításokat követve. 


\section{EREDMÉNYEK ÉS TÁRGYALÁSUK}

\subsection{A PHA-K RAKTÁROZÁSA T. ROSEOPERSICINA-BAN}

Számos fotoszintetikus baktérium képes jelentős mennyiségben PHA-kat raktározni (Liebergesell és mts., 1991; De Philppis és mts., 1992; Mas és Van Gemerden., 1995). Rb. spharoides-ben az ecetsav a legjobb szubsztrát a PHA-k raktározásához (Brandl és mts., 1991; Khatipov és mts., 1998).

A heterotróf baktériumokban a PHA-k szintézise a tápoldat nitrogén tartalmához kapcsolt (Anderson és Dawes, 1990) és ez a nitrogén kapcsoltság a fotoszintetikus baktériumban is megfigyelhető (Liebergesell és mts., 1991; De Philppis és mts., 1992).

Az előzményekben (lásd: Irodalmi áttekintés) ismertetett adatokból kiindulva a $T$. roseopersicina sejteket különböző szubsztrátokon (ecetsav, glutaminsav, piroszőlősav, borostyánkősav), különböző növekedési körülmények mellett (nitrogénfixáló és nem nitrogénfixáló) növesztettem, hogy megtaláljam a PHA raktározás szempontjából optimális szénforrást, illetve az ideális $\mathrm{C} / \mathrm{N}$ arányt. A glutaminsav ideális nitrogénforrás, mivel az ammóniával ellentétben a nitrogenázok aktivitását nem gátolja, illetve nem igényel extra energiát, mint a légköri $\mathrm{N}_{2}$ redukálása (Jouanneau és mts., 1984).

Az eredményeim azt mutatják, hogy számos egyéb bíbor baktériumhoz hasonlóan, $T$. roseopersicina-ban is az ecetsav a legjobb szubsztrát (Liebergesell és mts., 1991; Brandl és mts., 1991; Khatipov és mts., 1998). Az általam vizsgált körülmények között az ideális C/N (122:1) arányt a $10 \mathrm{~g} \mathrm{l}^{-1}$ ecetsav/0,17 $\mathrm{gl}^{-1}$ glutaminsav biztosította, amikor is a sejtek száraz tömegének 30,5£4 \%-át polihidroxi-alkánsavak alkották.

A liofilizált sejtek metil-észterifikálást követő gázkromatográfiás vizsgálata azt mutatta, hogy a T. roseopersicina PHBV kopolimert raktároz, mely 3-hidroxi-vajsav (3-HB) és 3-hidroxi-valeriánsav (3-HV) monomerekból épül fel (4. táblázat). A 3-HV eloszlása 5-41 mol\% között változott, a növesztési körülmények függvényében. A 3-hidroxi-vajsav és a 3hidroxi-valeriánsav mennyiségének mol\%-os megoszlása fordított arányosságot mutat a $\mathrm{C} / \mathrm{N}$ hányadossal. Az $5 \mathrm{~g} \mathrm{I}^{-1}$-es ecetsav (19 mM) koncentrációnál - nitrogén limitáló környezetben - a 3-HB és 3-HV mol\% megoszlása 69,8 mol\%, illetve 30,2 mol\%. Az ecetsav mennyiségének $10 \mathrm{~g} \mathrm{I}^{-1}$ - re (37 mM) való emelésével ez az arány 94,7 mol\% (3-HB) és 5,3 mol\%-ra (3-HV) 
csökkent. Magasabb ecetsav koncentráció mellett a sejtek már nem voltak képesek növekedni (4. táblázat).

\begin{tabular}{|l|c|c|c|c|c|}
\hline $\begin{array}{l}\text { Növesztési } \\
\text { körülmények }\end{array}$ & $\begin{array}{c}\mathrm{C}_{4} \\
\text { monomer } \\
\text { w\% }\end{array}$ & $\begin{array}{c}\mathrm{C}_{4} \\
\text { monomer } \\
\text { mol\% }\end{array}$ & $\begin{array}{c}\mathrm{C}_{5} \\
\text { monomer } \\
\text { w\% }\end{array}$ & $\begin{array}{c}\mathrm{C}_{5} \\
\text { monomer } \\
\text { mol\% }\end{array}$ & $\begin{array}{c}\text { Teljes PHA } \\
\text { tartalom } \\
\text { w\% }\end{array}$ \\
\hline $\begin{array}{l}5 \mathrm{~g} \mathrm{I}^{-1} \text { ecetsav, } \\
\mathrm{NC}_{\text {táp }}\end{array}$ & 6.8 & 69.8 & 3.3 & 30.2 & 10.1 \\
\hline $\begin{array}{l}10 \mathrm{~g} \mathrm{I}^{-1} \text { ecetsav, } \\
\mathrm{NC} \mathrm{táp}^{10 \mathrm{~g} \mathrm{I}^{-1} \text { ecetsav, }}\end{array}$ & 28.8 & 94.7 & 1.8 & 5.3 & 27.7 \\
$0,17 \mathrm{~g} \mathrm{I}^{-1} \mathrm{Glu}$ & 31 & 93.5 & 2.5 & 6.5 & 30.5 \\
\hline $\begin{array}{l}15 \mathrm{~g} \mathrm{I}^{-1} \mathrm{~T} \text {, } \\
0,17 \mathrm{~g} \mathrm{I}^{-1} \mathrm{Glu}\end{array}$ & 1.6 & 58.6 & 1.3 & 41.4 & 2.9 \\
\hline
\end{tabular}

4. táblázat. T. roseopersicina-ban, a különböző szubsztrátok jelenlétében raktározott polihidroxi-alkánsavak összetétele. Glu- glutaminsav; T- tioszulfát; NC- nitrogén fixáló körülmények;

A fototróf bíbor baktériumokban a PHA-k előfordulását vizsgálva legalább 28 faj (14 bíbor nem kén- és 14 bíbor kén baktérium) esetében mutatták ki, hogy ecetsav jelenlétében (6,5 mM) képesek poliésztereket raktározni (Liebergesell és mts, 1991).

Ezek közül 22 faj esetében kizárólag a PHB raktározását figyelték meg. A raktározott poliészter a sejt száraztömegének csupán 5\%-át tette ki.

Ezen ecetsav koncentráció mellett a fototróf bíbor kénbaktériumok, a sejtek száraz tömegének 5-28,6 \%-ában képesek PHA-kat raktározni, mely kizárólag 3-HB monomereket tartalmaz.

A R. rubrum és $R$. spaeroides bíbor nem kén baktériumokban ecetsav vagy ecetsav és almasav, borostyánkősav, glükóz vagy propionsav jelenlétében a raktározott PHA-k a sejtek 
száraz tömegének akár 50-65\%-t is poliészterek alkották. Minden esetben a polimer 98\% 3HB-ot és 2\% 3-HV-ot tartalmazott (Brandl és mts., 1991).

A $T$. roseopersicina úgyan jóval magasabb ecetsav koncentráció jelenlétében (122mM), de az egyik legjobb poliészter raktározó fajnak bizonyult, mely egyedüli bíbor kénbaktériumként PHBV kopolimert raktároz, amikor az ecetsav, mint egyedüli szénforrás van jelen a tápoldatban.

A piroszőlősav, borostyánkősav és glükóz tartalmú tápoldatokon növesztett $T$. roseopersicina sejtekben, nem tudtam polihidroxi-alkánsavak jelenlétét kimutatni. A tioszulfát, mint kizárólagos elektrondonor jelenlétében is csak elenyésző mennyiségben voltak jelen a PHA-k, mivel ebben az esetben szénforrás nem volt jelen a tápoldatban.

\subsection{A PHA METABOLIZMUSBAN RÉSZTVEVŐ GÉNEK AZONOsítÁSA THIOCAPSA ROSEOPERSICINA-BAN}

A PHA-k bioszintézisben résztvevő gén azonosításához, az $A$. vinosum (a $T$. roseopersicina közeli rokona) PHA szintáz (PhaC) fehérje szekvencájához legjobban hasonlító (homológ) régiót kerestem meg a $T$. roseopersicina genomban (nem publikált adatok). A TBLAST keresést követően, a homológ phaC DNS régió azonosítása után, a phaC génhez képest 5' és 3' irányban elhelyezkedő nyitott leolvasási kereteket (open reading frame) kerestem. A keresés eredményeképpen két genomi lókuszt azonosítottam.

Az egyik lókusz a phaARPBEC, mely tartalmazta a PHA-k bioszintézisében résztvevő géneket. A PHA-k lebontásában résztvevő PHA depolimerázt (phaZ) kódoló gént, a genom egy másik, különálló régiójában találtam meg.

A PHA-k bioszintézisében érintett lókuszon a gének két - ellentétes irányítottságú génklaszterbe rendeződnek. Az egyik génsorozatot a phaARPB gének alkotják, melyek a $\beta$ ketotiolázt (phaA), a PHA bioszintézisét szabályozó fehérjét (phaR), a poliészter granulumhoz kapcsolódó fazin fehérjét (phaP) és a NADPH függő aceto-acetil-CoA reduktáz enzimet (phaB) kódolják. A másik génklaszterben az ellentétes irányítottságú phaC-phaE gének találhatóak (11. ábra), melyek egy kétkomponensű PHB szintázt kódolnak. 

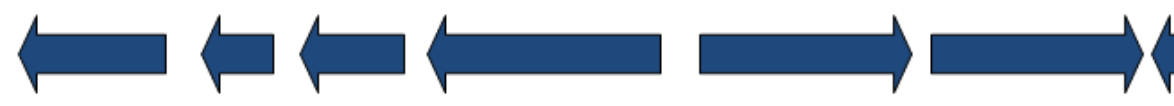

phaB phaP phaR phaA

phaE

phaC

rsam

11. ábra. A T. roseopersicina pha lókusz genetikai térképe.

A phaARPB és phaCE génekről átíródott fehérjék többszörös illesztése során nagy relatív azonossági értékeket találtam számos $\gamma$-Proteobaktérium megfelelő fehérjéivel (4. táblázat): a PhaA esetében 44-91\% (legmagasabb a T. violacea PhaA), a PhaR esetében 7680\% (legmagasabb a T. violacea PhaR), a PhaP esetében 23-71\% (legmagasabb az A. vinosum PhaP) és a PhaB esetében 41-87\% (legmagasabb A. vinosum PhaB) között változott. A PhaC és PhaE fehérjék esetében ez az érték $51-89 \%$ (legmagasabb az $A$. vinosum PhaC) és 24-72\% (legmagasabb a T. violacea PhaE) között változott.

A T. roseopersicina-ban, a PHA bioszintézisben résztvevő gének genetikai elrendeződése nagyfokú hasonlóságot mutatott az $A$. vinosum pha lókuszával (Liebergessel és Steinbüchel, 1992).

A szintázok a poliészter kialakulásának kulcsenzimei, melyek a $\beta$-hidroxi-zsírsav monomerek beépülését katalizálják a polimer láncba. Szerkezetük és szubsztrát specificitásuk alapján a poliészter szintázokat négy osztályba (I.-IV. osztály) sorolják (Id.2.4.7. fejezet).

A T. roseopersicina egy két alegységes szintázt tartalmaz (a polimerázt (PhaC) és egy feltehetően poliészterkötő alegységet (PhaE), mely alapján a III. osztályú szintázok osztályába sorolható. Kísérleteim alátámasztják, hogy ezen enzim is a 3-5 szénatomos (R)-3hidroxi-CoA tioésztereket (3-HB és 3-HV) építi be a poliészter láncba (Isd. 5.1. fejezet), mint ahogyan már korábban leírták (Yuan és mts., 2001).

Az A. vinosum PhaC szintáz katalitikus aminosavai (Cys-149, His-331 és Asp-302), azonos poziciókban a $T$. roseopersicina-ban is megtalálhatóak és nagy valószínűséggel, úgyancsak katalitikus funkcióval rendelkeznek.

Egy átfogó tanulmány során Rehm (2007) az találta, hogy a PhaC fehérjék között jóval nagyobb hasonlóság figyelhető meg, mint a PhaE fehérjék között. 


\begin{tabular}{|c|cccccc|}
\hline & \multicolumn{6}{|c|}{ Thiocapsa roseopersicina BBS-ben a PHA-k } \\
& bioszintézisében részt vevő fehérjék \\
& A & B & C & E & P & R \\
\hline A.vinosum DSM180 & 88 & 87 & 89 & 70 & 71 & 76 \\
& & & & & & \\
\hline E. shaposhnikovii & 73 & - & 69 & 38 & 23 & - \\
\hline T.violacea & 91 & - & 86 & 72 & - & 80 \\
\hline Synecocystis sp. PCC 6803 & 44 & 41 & 55 & - & - & - \\
\hline Cyanothece sp. PCC 7424 & - & - & 51 & 24 & - & - \\
\hline T. pfennigii & - & - & 83 & 54 & - & - \\
\hline & & & & & & \\
\hline
\end{tabular}

5. táblázat. A T. roseopersicina PHA-bioszintézisében részt vevő fehérjék, többszörös illesztése során kapott relatív azonossági értékek (\%)

A PhaE alegységeket összehasonlítva, a fehérje C-terminális régiójában két rövid aminosav szakaszt talált, melyek a PHA granulum kötő fehérjékre (fazin) jellemzőek. A PhaE fehérjének, a PHA szintáz, granulumhoz való kötésében lehet szerepe, de a pontos funkciója egyelöre ismeretlen (Rehm, 2007).

A. III. típusú szintázt tartalmazó mikroorganizmusoknál megfigyelt phaC és phaE gének kapcsoltsága (Müh és mts., 1999) T. roseopersicina esetében is feltételezhető (11. ábra), mivel minden jel arra mutat, hogy a két fehérje egy funkcionális egységet alkot.

A 5. táblázatot megfigyelve feltúnik, hogy a PhaA, PhaB és $P h a C$ fehérjék között nagyobb azonossági értékek figyelhetőek meg, mint a PHA bioszintetikus lókusz többi fehérjéi között.

Korábban számos fajban leírták, hogy a PHA szintáz és számos egyéb, a PHA-k bioszintézisében érintett gének kapcsoltan helyezkednek el a bakteriális genomon belül, és ezen túlmenően, feltúnő a phaCAB gének kapcsoltsága is (pl. C. necator stb.; Rehm és Steinbüchel, 1999). Habár a T. roseopersicina-ban a phaC, phaA, PhaB gének nem kapcsoltak, 
a megfelelő fehérjék esetében tapasztalt nagy fokú azonosság további vizsgálatokat kívánt, hogy kiderítsem ezen gének eredetét.

Ezzel ellentétben a kisebb szekvencia azonosságot mutató PhaR, PhaP és PhaE fehérjéket kódoló gének a különböző fajokban, feltételezhetően a poliészter raktározás "finom szabályozását" végzik. A különböző élettereket benépesítő mikroorganizmusokban, ezen gének változatai biztosítják azon különbségeket, melyek a granulumok összetételében, méretében stb. nyilvánulnak meg.

A polihidroxi-alkánsavak bontásában részt vevő PHA depolimeráz gént (phaZ) a bioszintézisben részt vevő génektől távol elhelyezkedő, másik genomi régió tartalmazta. A poliészter depolimerázok az $\alpha / \beta$ hidrolázok családjába tartozó karboxil-észterázokhoz hasonló enzimek (Jendrossek és Handrick, 2002).

A legismertebb $\mathrm{dPHA}_{\mathrm{rsl}}$ depolimerázok közös domén szerkezettel rendelkeznek, melyek egy rövid szignál peptidet (egyes esetekben hiányozhat), egy katalitikus domént (beleértve a lipáz motívumot és az oxi-anion üreget), egy rövid összekötő régiót és egy szubsztrát kötő domént tartalmaznak (Behrends és mts., 1996). Habár a PHA depolimerázok és más $\alpha / \beta$ hidrolázok (lipázok, észterázok) szekvenciái között csak kis fokú hasonlóság figyelhető meg - a nagyon eltérő szubsztrát specificitás miatt - ugyanazon család tagjai és nagyon konzervált katalitikus centrummal (szerin-hisztidin-aszpartát) rendelkeznek.

A T. roseopersicina PhaZ depolimeráz fehérjeszekvenciáját, a PHA depolimeráz adatbázisban (Knoll és mts., 2009) elemezve, azt találtam, hogy az 1. típusú katalitikus doménnel rendelkező extracelluláris $\mathrm{dPHA}_{\mathrm{rsl}}$ depolimerázokhoz mutat nagy hasonlóságot, vagyis az oxi-anion aminosav, a lipáz motívum $\mathrm{N}$ terminális régiójában helyezkedik el.

A T. roseopersicina PhaZ fehérjéjében megtaláltam a korábban leírt szerkezeti egységeket (kivéve szignálpeptid szekvenciát), továbbá azonosítottam az extracelluláris depolimerázokra jellemző konzervált aminosavakat: a hisztidint (oxianion), illetve az aktív centrumot kialakító, a G-L-[S]-A-G lipáz motívumba ágyazott katalitikus szerint, valamint az ugyancsak katalitikus aktivítással rendelkező aszparaginsavat és a hisztidint is. Habár ezen depolimeráz az extracelluláris depolimerázokkal mutat legnagyobb hasonlóságot, a szignál szekvencia hiánya, illetve az a tény, hogy a $T$. roseopersicina (korábbi megfigyeléseink) a poliésztereket sejten belül raktározza, arra enged következtetni, hogy az intracelluláris poliészter granulumok lebontásában is részt vesz. 
A PhaZ depolimeráz fehérjeszekvenciájának többszörös illesztése azt mutatta, hogy a T. roseopersicina depolimeráz nagyfokú azonosságot mutat a Xanthobacter autotrophicus Py2 (53\%), Methylobacterium extorquens fajok (52\%), Azotobacter vinelandii DJ (48\%) és $A$. vinosum DSMZ 180 (38\%) fajokban talált depolimerázokkal.

Az $\alpha$-proteobaktériumokhoz tartozó fajok, megfelelő fehérjéivel (Xanthobacter autotrophicus Py2, Methylobacterium extorquens fajok, Azotobacter vinelandii DJ) szemben mutatott nagymértékű azonosság arra enged következtetni, hogy a depolimerázt kódoló DNS szekvencia, a PHA-k bioszintézisében részt vevő génekhez képest (ezen fehérjék $\gamma^{-}$ Proteobaktériumok megfelelő fehérjéivel mutatnak hasonlóságot; lásd: 5. táblázat) a baktérium evolúciójának egy másik szakaszában kerülhetett a genomba, ezért a későbbiekben kodon adaptációs index, illetve filogenetikai vizsgálatokat végeztem.

Mivel korábban számos mikroorganizmusban leírták, hogy a PHA-k anyagcseréjében érintett gének több példányban is jelen lehetnek a genomban ( $p l$ : $C$. necator-ban a phaZ gén hat példányban, a fazin fehérje négy példányban; a Burkholderia fungorum-ban a phaz két példányban van jelen stb. (Pötter és mts., 2004; Kadouri és mts., 2005), ezért a $T$. roseopersicina-ban is, további a poliészter anyagcserében érintett gént kerestem.

A $T$. roseopersicina genom alapos vizsgálata során nem találtam további olyan gén(eke)t, melyeknek szerepe lehet a PHA-k szintézisében vagy lebontásában.

\subsection{A PHAC ÉS PHAZ FEHÉRJÉK FILOGENETIKÁJA}

A T. roseopersicina és az A. vinosum törzsek megfelelő PhaA, PhaB és PhaC fehérjéit összehasonlítva (88, 87 illetve 70\%) jóval nagyobb azonosság volt megfigyelhető (4. táblázat), mint a PhaZ fehérje (38\%) esetében. Ez a megfigyelés sugallta, hogy a kapcsolódó gének/fehérjék esetében, érdemes megvizsgálni a kodon felhasználást és a filogenetikai törzsfát. Modell szekvenciaként a PHA szintáz, PhaC alegységét (a PHA bioszintetikus útvonal legkonzerváltabb fehérjéje) és PHA depolimeráz (PhaZ) fehérjéket használtam.

Bár az aminosavakat kódoló kodonok gyakorlatilag univerzálisak, a különböző mikroorganizmusok eltérő gyakorisággal használják az azonos aminosavakat kódoló tripleteket, vagyis egyes kodonokat előnyben részesítenek. 
A kodon adaptációs index (CAI) egy olyan mérőszám, mely segít megítélni egy gén korát egy adott genomon belül. Minél későbben került egy gén az adott faj genomjába, annál kisebb mértékben alkalmazkodott a gazdafaj kodon preferenciájához.

A phaC és phaZ gének esetében számolt CAl értékek nem mutattak eltérést a két gén kodon felhasználásában, így a géntranszfer idejét illetően, következtetéseket nem lehetett levonni, ezért további vizsgálatokat végeztem.

A T. roseopersicina-ban a poliészter bioszintézisében (PhaC) és lebontásában (PhaZ) részt vevő reprezentatív fehérjeszekvenciákat használva filogenetikai fát készítettem. A törzsfa elkészítéséhez mind a négy PHA szintáz család reprezentatív képviselőinek fehérjeszekvenciáját (Rehm, 2003), valamint ugyanezen, illetve ezekhez közeli rokonságot mutató törzsek PhaZ fehérjék aminosav sorrendjét használtam a 4. fejezetben (lásd: Anyagok és Módszerek) leírt munkamenetet követve.

A $T$. roseopersicina PhaC fehérjéje egy elágazást alkot az A. vinosum, Thiocystis violaceae és Thiorhodococcus drewsii fotoszintetikus $\mathrm{Y}$-Proteobaktériumokkal. Továbbá közeli rokonság figyelhető meg a Synechocystis sp. PCC 6803 cianobaktériummal (12. ábra), melyet a korábban bemutatott irodalmi adatok is alátámasztanak, vagyis a cianobaktériumokra jellemző III. típusú poliészter szintáz is egy közös őstől származtatható (Hai, 2001).

Korábbi filogenetikai elemzésekben 67 különböző proteobakteriális PhaC fehérje és a megfelelő fajok 16S rDNS törzsfájának összehasonlító vizsgálata azt mutatta, hogy a törzsfák csaknem teljesen átfednek és a PhaC fehérjék is a fajok filogenetikai taxonómiája alapján csoportosulnak (Kadouri és mts., 2005).

Kadouri és mts. (2005) azt is megfigyelték, hogy phCAB gének a különböző fajokban nagyon gyakran kapcsoltak, továbbá, hogy a különböző fajok PhaA, PhaB és PhaC fehérjéit és a megfelelő 16S rDNA törzsfákat összehasonlítva nagyon nagy mértékű átfedés volt tapasztalható, ami azt sugalta, hogy ezen gének "beszerzése" proteobaktériumokban egy nagyon régi folyamat eredménye. 

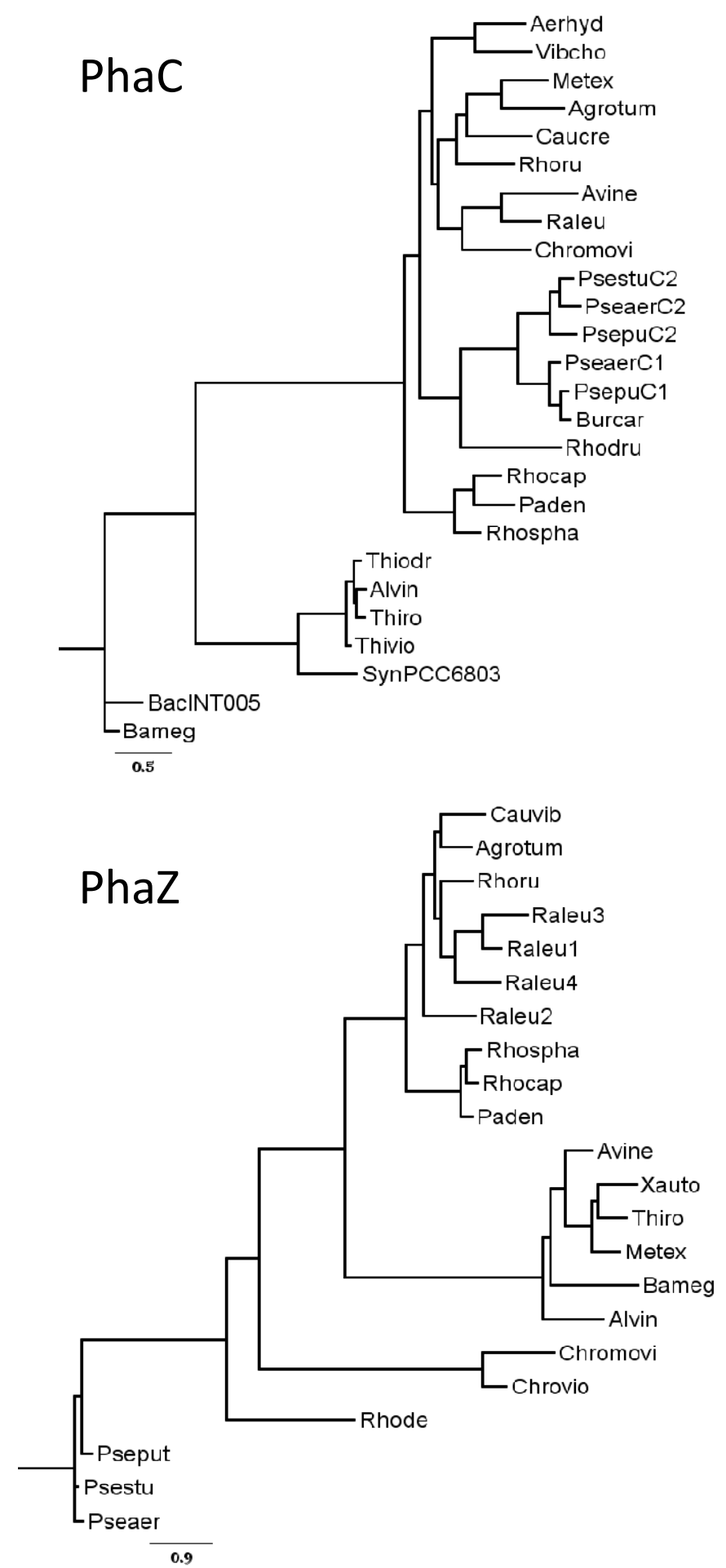

12. ábra. A PhaC és PhaZ fehérjék filogenetikai törzsfái.

Aerhyd: Aeromonas hydrophila, Agrotum: Agrobacterium tumefaciens, Alvin: Allochromatium vinosum, Avine: Azotobacter vinelandii, Bameg: Bacillus megaterium, BacINT005: Bacillus sp. INT005, Burcar: Burkholderia caryophylli, Caucre: Caulobacter crescentus CB15, Cauvib: Caulobacter vibrioides Chromovi: Chromobacterium violaceum, Metex: Methylobacterium extorquens, Paden: Paracoccus denitrificans, PseaerC1, PseaerC2: Pseudomonas aeruginosa PcaC1, PcaC2, PsepuC1, PsepuC2: Pseudomonas putida PcaC1, PcaC2, PsestuC2: Pseudomonas stutzeri PcaC2, Raleu: Ralstonia eutropha, RaleuZ1, RaleuZ2, RaleuZ3, RaleuZ4,: Ralstonia eutropha PcaZ1,Z2,Z3,Z4, Rhocap: Rhodobacter capsulatus, Rhospha: Rhodobacter sphaeroides, Rhodru: Rhodococcus ruber, Rhode: Rhodococcus equi, Rhoru: Rhodospirillum rubrum, SynPCC6803: 
Synechocystis sp. PCC 6803, Thiro: Thiocapsa roseopersicina, Thivio: Thiocystis violacea, Thiodr: Thiorhodococcus drewsii, Vibcho: Vibrio cholerae V51, Xauto: Xanthobacter autotrophicus

Eredményeim nagyon jól átfednek a korábbi megfigyelésekkel, amit a különböző fajokból származó PhaA, PhaB és PhaC fehérjék között tapasztalt nagyfokú szekvencia azonosság is alátámaszt, annak ellenére, hogy a $T$. roseopersicina-ban a phaABC gének nem kapcsoltak.

A PhaZ fehérje esetében a $T$. roseopersicina PHA depolimeráza közeli rokonságot mutat a nem fotoszintetizáló Xanthobacter autotrophicus és Methylobacterium extorquens $\alpha$ proteobaktérium fajok megfelelő fehérjéivel és négy elágazási pont figyelhető meg a $T$. roseopersicina és $A$. vinosum depolimeráz enzimei között (12. ábra).

A különböző PhaC és PhaZ fehérjék esetén megfigyelt azonossági értékek (86-90\% és 52-53\% ), illetve, hogy a T. roseopersicina PhaC fehérje filogenetikai csoportja jóval korábban ágazik el mint a $T$. roseopersicina PhaZ csoportja, ami egy nagyon késői elágazása a filogenetikai törzsfának, egyértelmúen mutatják, hogy a PHA anabolikus és katabolikus gén(ek)/enzimek egymástól független evolúció eredményei és fetételezhetően horizontális géntranszfer révén, más-más időpontokban kerültek be, ezen $\gamma$ Proteobaktérium genomjába.

Ezen megfigyelésemet egy korábbi, a különböző fajokból származó iPhaZ fehérjék és ugyanezen fajok $16 \mathrm{~S}$ rDNS filogenetikai fáinak összehasonlító vizsgálata is alátámasztotta, amikor is, a két törzsfa között csak kis átfedés volt megfigyelhető. Ez alapján feltételezték, hogy ezen gének is horizontális gén transzfer útján kerültek a genomokba (Kadouri és mts., 2005)

A C. necator genomban hat különböző phaz gént azonosítottak Ezen gének megtöbbszöröződése azt mutatja, hogy egy adott baktérium a különböző típusú poliészterek lebontására is képes lehet (Kadouri és mts., 2005).

A T. roseopersicina PHA-k bioszintézisében és lebontásában részt vevő fehérjék összehasonlító vizsgálata során kapott eredmények megegyeznek a korábbi irodalmi adatokkal, megerősítve, hogy a poliészter raktározási képesség egy nagyon konzervált ősi folyamat, mely evolúciós előnyt jelent. A poliészterek bontásában részt vevő enzimek esetében tapasztalt sokszínűség arra utal, hogy a mikroorganizmusok számára az is nagyon lényeges, hogy az általuk raktározott PHA-k mellett, a sejtek környezetébe kijutott idegen 
eredetű, illetve különböző típusú és méretű poliésztereket, mind könnyen elérhető szén és energiaforrást is hasznosítani tudják.

Figyelembe véve, hogy a poliészterek raktározásának fontos szerepe van a mikroorganizmusok túlélésében, stressz türésében, illetve számos egyéb biológiai folyamathoz kapcsolódnak (lásd: Irodalmi áttekintés ), ésszerű feltételezni, hogy poliészter raktározási és lebontási képesség "egy evoluciós adú" a túléléshez, a folyamatosan változó körülmények között.

\subsection{A PHA DELÉCIÓS MUTÁNS ELŐÁLLÍTÁSA ÉS JELLEMZÉSE}

A polihidroxi-alkánsavak és a hidrogén metabolizmus közötti kapcsolatok feltárása érdekében, egy a poliészterek raktározására nem képes mutáns törzset hoztam létre.

A deléciós mutáns elkészítéséhez a $T$. roseopersicina pha lókuszának 5'- és 3'régióiból egy-egy kb. 1000 bp tartalmazó szakaszt a DNS polimeráz láncreakció során, a PHADo1 és PHADo2, illetve PHADo7 és PHADo8 primerek segítségével felsokszoroztam, majd a genomi orientációjuknak megfelelően, egy szúk gazdaspecificitású pK18mobsacB vektorba (Shaffer és mts., 1994) klónoztam (13. ábra; részletesen lásd: Anyagok és Módszerek).

A kész plazmidot E. coli S17-1 ( $\lambda$ pir) törzsbe transzformáltam, majd konjugációval az aktív hidrogenázt nem tartalmazó DC12B (Maróti és mts., 2003) T. roseopersicina törzsbe jutattam be. A homológ rekombináció révén létrejött mutánsokat a sacB pozitív szelekciós rendszer (Shaffer és mts., 1994) segítségével azonosítottam.

A deléció sikerességét a PHBMo5 és PHBMo6 PCR primerekkel kapott termékek mérete, továbbá szekvenálása is megerősítette (13. ábra). Az így kapott törzset PH12B-nek neveztem el.

A gázkromatográfiás elemzések során kiderült, hogy a PHA bioszintetikus lókuszt nem tartalmazó PH12B törzs $10 \mathrm{~g} \mathrm{I}^{-1}$ ecetsav és $0,17 \mathrm{~g} \mathrm{I}^{-1}$ glutaminsav tartalmú tápoldatban növesztve, nem képes poliésztereket raktározni.

A PHA raktározási lépés során (PR-tápoldatban) mindkét törzs (DC12B és PH12B) képes volt magas ecetsav koncentráció $\left(10 \mathrm{~g} \mathrm{I}^{-1}\right)$ jelenlétében növekedni, sőt a PH12B törzs, a DC12B törzshöz viszonyítva, nagyobb sejtszámot ért el. 


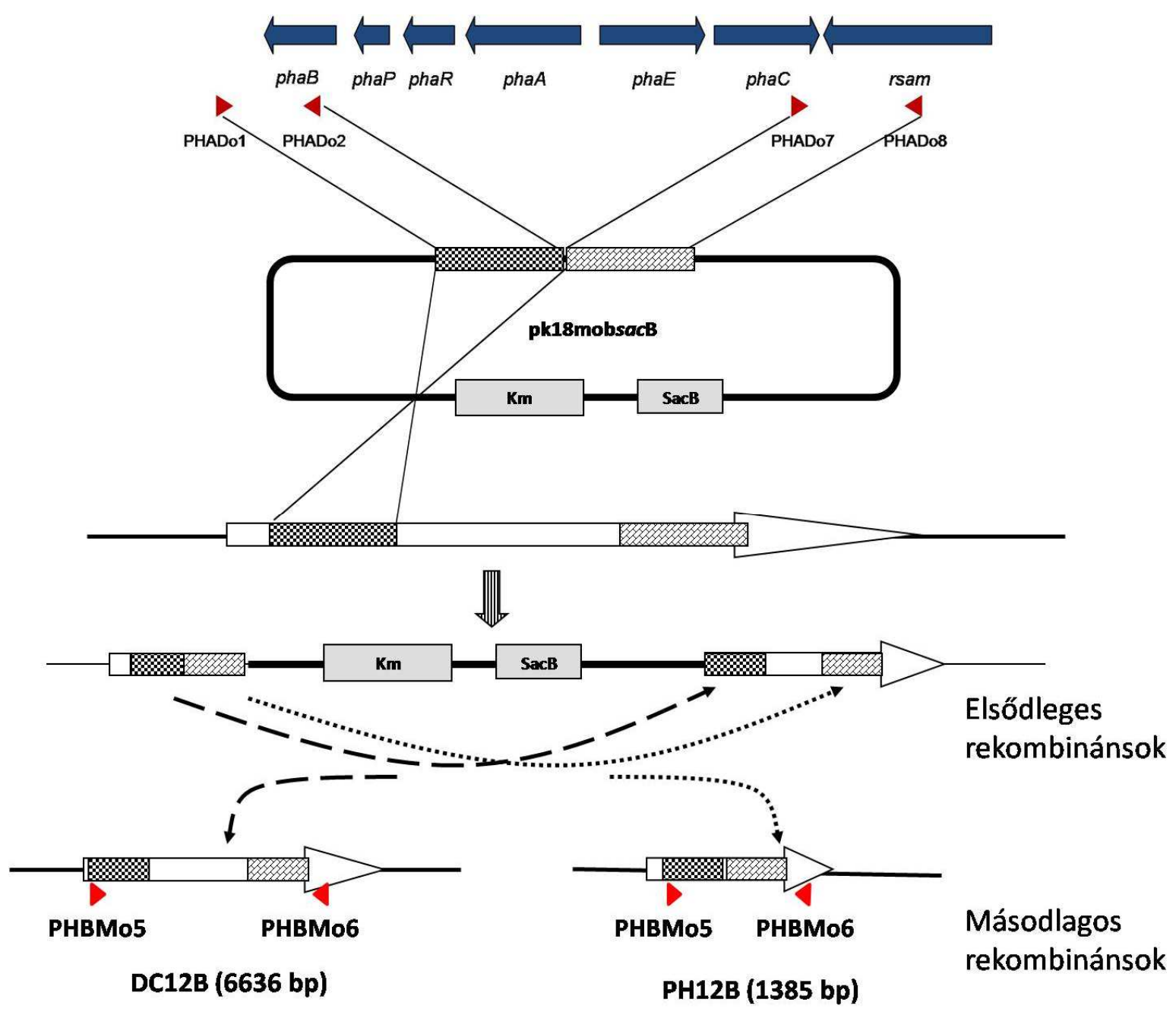

13. ábra. A PH12B deléciós mutáns készítésének sematikus rajza.

A DC12B törzs és a PH12B közötti növekedésbeli különbség alapján feltételezhető, hogy a DC12B sejtekben raktározott PHA granulumok egy része, néhány sejt szétesése révén kikerült a tápoldatba és megnövelte a kultúra turbiditását, így gátolva a fény eljutását a sejtekhez. Ezért tartottam nagyon fontosnak, hogy a poliészter raktározási szakaszt követően, a hidrogén termelési szakasz előtt, a kultúrák optikai súrúségét $\left(\mathrm{OD}_{600}\right)$ megközelítőleg azonos értékekre állítsam be $\left(0,8-0,9-\mathrm{cm}^{-1}\right)$, így biztosítva a sejtkultúrák közel azonos fényáteresztő képességét a hidrogén termelési szakasz során. 


\subsection{A PHA-K SZEREPE A HIDROGÉN TERMELÉSBEN}

A fototróf baktériumban az ecetsav, mint a PHB raktározás, mint a hidrogén termelés számára előnyős szubsztrát. Habár, két különböző metabolikus folyamat érintett, ezek meglehetősen átfednek és számos kísérlet is igazolta, hogy a két folyamat egy időben nem valósítható meg (De Philippis és mts., 1992; Hustede és mts., 1993).

A Rhodovulum sulfidophilum sejtekben raktározott PHB, mint egyetlen szubsztrát, a nitrogenáz révén hidrogén termelésre felhasználható (Maeda és mts., 1997).

Amint már korábban ismertettem, a bíbor nem kén baktériumokban az aktív hidrogenázok hiányában fokozódik a hidrogén termelés különösen, ha hidrogén visszavevő aktivitással rendelkező enzimeket nem tartalmaznak a sejtek ( $R$. capsulatus, Jahn és mts., 1994; Worin és mts., 1996); $R$. rubrum ,Kern és mts., 1994).

Munkám során olyan nitrogén limitált körülményeket alkalmaztam, ahol a nitrogenáz termeli a hidrogént. Ilyen körülmények között a hidrogenázok a hidrogén visszavétel irányába múködnek és a hidrogén oxidációját katalizálják.

A fentiek ismeretében, kísérleteimhez egy már korábban létrehozott, aktív hidrogenázt nem tartalmazó $T$. roseopersicina törzset (DC12B; Maróti és mts., 2003) választottam. Ez, egy csoportunk által létrehozott dupla mutáns törzs ( $\Delta h y p C_{1}$ és $\Delta h y p C_{2}$ ), melyben a HypC1 és HypC2 pleiotróp fehérjék hiányában a [NiFe] hidrogenázok nem expresszálódnak (Maróti és mts., 2003). Ezen a genetikai háttéren, egy a polihidroxialkánsavak raktározására nem képes, mutáns törzset (PH12B; lásd: Anyagok és Módszerek illetve Eredmények és tárgyalásuk) hoztam létre.

Kísérleteim során a DC12B és a PH12B sejtkultúrákban, a poliészter bontás és a hidrogén termelés kapcsolatát vizsgáltam.

Ecetsav jelenlétében növesztett fototróf baktériumokban a PHB raktározás és a $\mathrm{H}_{2}$ termelés verseng a redukáló erőért (De Philippis és mts., 1992; Hustede és mts., 1993).

A korábbi megfigyelések is alátámasztják, hogy az egyszer raktározott PHB hidrogén termelésre felhasználható, de a hatékony $\mathrm{H}_{2}$ termelés érdekében a PHA raktározási és a $\mathrm{H}_{2}$ termelési lépést el kell választani egymástól. 

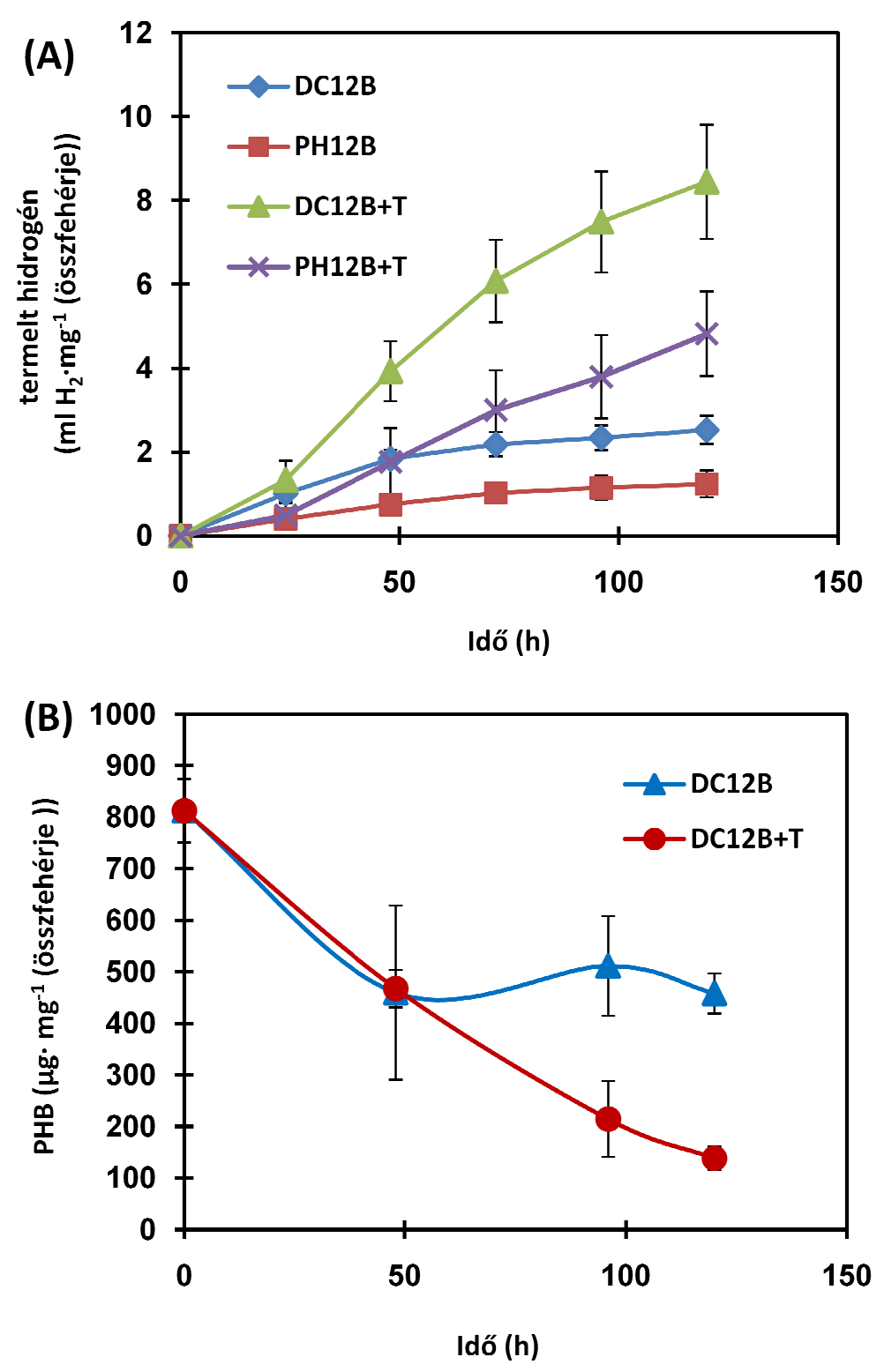

14. ábra. A nitrogenáz katalizálta hidrogén termelés $(\mathrm{A})$ és a raktározott $\mathrm{PHB}$ mennyiségének a változása (B) a DC12B és PH12B törzsekben. A PH12B törzs esetében PHB raktározás nem volt megfigyelhető. $A$ “ $+\mathrm{T}^{\prime}$ jelzés ellátott törzsek $2 \mathrm{~g} \mathrm{I}^{-1}$ tioszulfátot tartalmaztak.

Ezen előzmények ismeretében a PHA raktározási körülmények között (PR tápoldat) növesztett $T$. roseopersicina sejtek tápoldatát, a hidrogén termelési szakaszt megelőzően, egy külső szén- és nitrogén forrást nem tartalmazó tápoldatra cseréltem (HT tápoldat), majd ezt követően mértem a sejtkultúrák hidrogén termelését (lásd: 4. Anyagok és Módszerek). 
A törzsek hidrogén termelő képességét összehasonlítva az 5 . nap végére a DC12B törzsben, a PH12B törzshöz viszonyítva, kb. kétszer nagyobb hidrogén termelés volt megfigyelhető $\left(2,52 \pm 0,33 \mu \mathrm{l} \mathrm{H} \mathrm{H}_{2} \mathrm{mg}^{-1}\right.$ (összfehérje), illetve 1,23 $\pm 0,31 \mu \mathrm{l} \mathrm{H}_{2} \mathrm{mg}^{-1}$ (összfehérje) (14A. ábra). A DC12B és $\mathrm{PH} 12 \mathrm{~B}$ törzsek hidrogén termelésében tapasztalt különbség egyértelműen a PHA-k lebontásához társítható (14B. ábra), mely a hidrogén termelés első 48 órájában nagyon intenzív. Az első 48 órát követően a DC12 törzsben PHA-k bontása leáll és ezen törzs biohidrogén termelése, a PH12B törzsben megfigyelt értékeket mutatja (14B. ábra).

Fontos megjegyezni, hogy a PH12B törzs képes volt kis mennyiségú hidrogént termelni (14A. ábra), annak ellenére, hogy a HT tápoldatban a sejtek számára nem volt elérhető sem külső szén, sem külső nitrogénforrás. Ez a maradék hidrogén termelés nagy valószínúséggel a raktározott tartalék tápanyagok, mint glikogén vagy elemi kén $\left(S^{0}\right)$ felhasználásához kapcsolható.

Ezt követően a különböző tápoldat jelenlétében inkubált DC12B és PH12B törzsek in vitro nitrogenáz aktivitását is megvizsgáltam, acetilén redukciós módszert használva.

Meglepő módon a $T$. roseopersicina [MoFe] nitrogenázának acetilén redukciós vizsgálatához, szükséges a nitrogén jelenléte, amit ez idáig nem sikerült megmagyarázni. Ez ellentmond a korábbi irodalmi állításoknak, miszerint a $N_{2}$ és az acetilén egy közös vagy megosztott szubsztrátkötő helyért versengenek (Kim és mts., 1995).

A HT tápoldatban inkubált $\mathrm{DC12B}$ és a $\mathrm{PH} 12 \mathrm{~B}$ kultúrák nitrogenáz aktivitását összehasonlítva nem találtam jelentős eltérést (15. ábra). Ez azt mutatja, hogy a PHA bioszintetikus lókusz eltávolítása nem érintette a nitrogenáz működését.

Ezen adatok tükrében megállapítható, hogy a poliészterek raktározára képes törzsnek (DC12B), a $\Delta$ pha mutáns törzshöz (PH12B) viszonyított kb. 50\%-al nagyobb hidrogén termelő képessége, a PHA-k jelenlétének tulajdonítható és nem a nitrogenáz csökkent aktivitásának (14A. ábra).

Az in vivo nitrogenáz mediált hidrogén termelés fényfüggőségét szintén teszteltem. A PHA raktározási lépést követően a minták felét sötétben inkubáltam. A DC12B és PH12B törzsek csak folyamatos megvilágítás mellett termeltek hidrogént, sötétben viszont hidrogéntermelés nem volt megfigyelhető. 


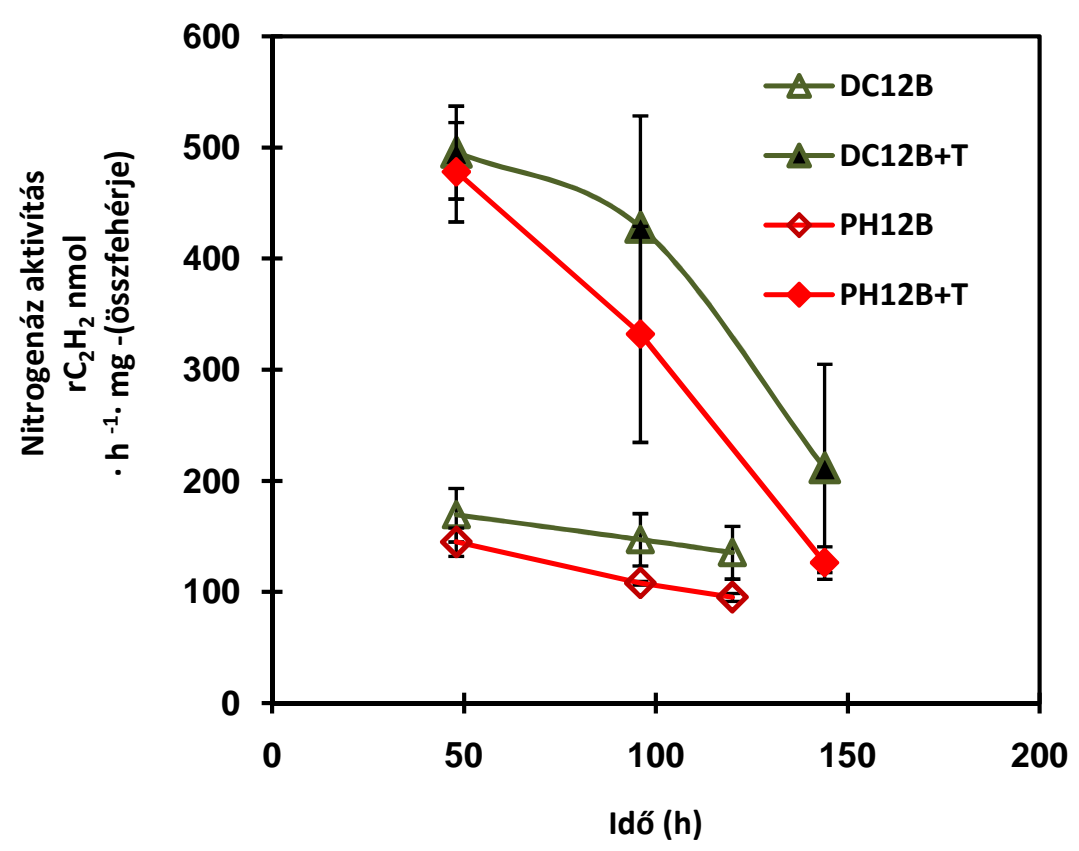

15. ábra. A DC12B és PH12B törzsek in vitro nitrogenáz aktivitása. $A$ “+T” jelzés ellátott törzsek $2 \mathrm{~g} \mathrm{I}^{-1}$ tioszulfátot tartalmaztak.

A fény jelenléte egy nagyon lényeges paraméter a nitrogenáz révén történő hidrogén termelésben. Jouanneau és mts. (1985) azt találták, hogy a fény nagyon erősen fokozza a sejtek nitrogenáz aktivitását és így a hidrogén termelő aktivitás is nagyobb. Nagy fényintenzitásnál növesztett sejtekben, kissé több ATP képződött, mint az alacsony fényintenzitás mellett sejteket mellett növekedett sejteknél (Steinborn és Oelze, 1989) és ez természetesen a termelt $\mathrm{H}_{2}$ mennyiségében is megnyilvánult.

Tehát, a $T$. roseopersicina-ban a poliészterek bontása során felszabaduló redukáló erőt, a nitrogenáz csak a fényenergia felhasználásával képes hatékonyan hidrogén termelésére fordítani, mivel feltehetően a sejtek csak így képesek fedezni, az ATP függő hidrogenázként működő nitrogenáz nagy energiaigényét (Steinborn és Oelze, 1989). 


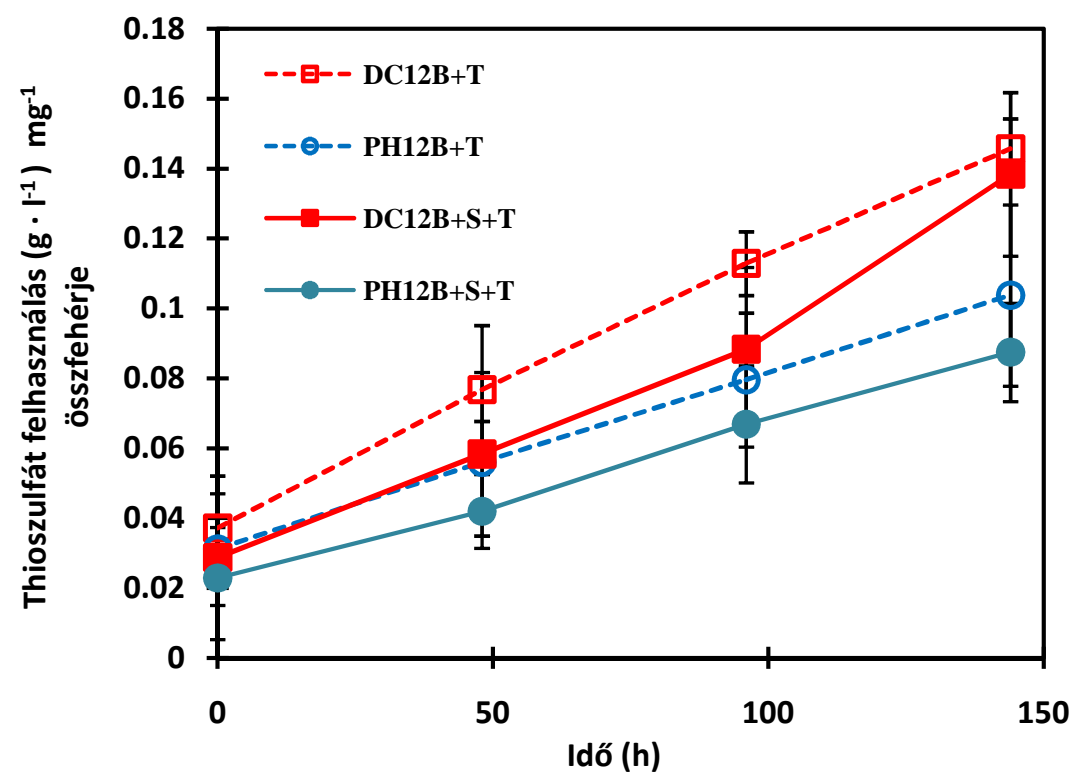

16. ábra. A PHAk raktározására képes (DC12B) és $\Delta p h a$ mutáns ( $\mathrm{PH} 12 \mathrm{~B})$ törzsek tioszulfát felhasználása. $A$ “ $+T^{\prime}$ ” jelzés ellátott törzsek $2 \mathrm{gl}^{-1}$ tioszulfátot, az “+S"jelzéssel ellátottak $5 \mathrm{~g} \mathrm{l}$ ${ }^{1}$ borostyánkősavat tartalmaztak.

\subsection{A TIOSZULFÁT ÉS BOROSTYÁNKŐSAV HATÁSA A PHA-K DEGRADÁCIÓRA ÉS A HIDROGÉN TERMELÉSRE}

A R. sulfidophilum bíbor nem kén baktériumban a borostyánkősav, az egyik legjobb szubsztrát a hidrogén termelésre (Maeda és mts., 1998). Maeda és mts. (2002) a különböző körülmények között növesztett (borostyánkősav; PHB; PHB és borostyánkősav) vad és és $\triangle p h a C$ mutáns törzsek hidrogén termelését hasonlították össze. Azt találták, hogy a $R$. sulfidophilum sejtekben a PHB kissé hatékonyabban használható fel a hidrogén termelésére mint a borostyánkősav, illetve a PHB és borostyánkősav szubsztrátok.

Mivel, csoportunk korábbi vizsgálatai kimutatták, hogy a $T$. roseopersicina-ban a fotoszintézis és hidrogéntermelés számára is a tioszulfát az elsődleges elektron donor, mind a központi redox rendszerhez és a hidrogén metabolizmushoz kapcsolódó kulcsvegyület (Rákhely és mts., 2007; Laurinavichene és mts., 2007), ezért elsősorban ennek hatását vizsgáltam. A tioszulfát mint az anaerob fotoszintézis fő elektronforrása nélkülözhetetlen a $T$. roseopersicina sejtek számára, ezért csak kivételes esetekben hagyható el a tápoldatból. A fiziológiás hidrogén termelési körülmények között számolni kell jelenlétével, illetve fontos 
megvizsgálni a hatását, a hidrogén termelésre használt szubsztrátoktól függetlenül (PHA, glikogén stb.).

A tioszulfát jelenlétének - mindkét törzsben - intenzív hatása van a hidrogén termelésre, vagyis tioszulfát jelenlétében, a külső szubsztrát hiányában tapasztalt értékekhez képest kb. négyszeres hidrogén termelés növekedés figyelhető meg (DC12B 8,44 $\pm 1,36 \mu \mathrm{I}_{2}$ $\mathrm{mg}^{-1}$ (összfehérje) és a PH12B $\left(4.81 \pm 1,00 \mu \mathrm{l} \mathrm{H}_{2} \mathrm{mg}^{-1}\right.$ (összfehérje) (14A. ábra).

Meglepő módon a tioszulfát fokozza a PHA-k bontását, mely az első 48 órában a legintenzívebb és az 5. napra a sejtek csaknem teljes poliészter állománya felhasználódik (14B. ábra).

A tioszulfáttal kiegészített HT tápoldatban mindkét törzsben nagy nitrogenáz aktivitását növekedés figyelhető meg, mely az inkubáció késői szakaszában visszatér a tioszulfát hiányában tapasztalt alapszintre (15. ábra).

A tioszulfát hozzáadását követően a PH12B törzshöz viszonyítva, a DC12B törzsben szignifikánsan nagyobb tioszulfát felhasználása figyelhető meg (kb. 40\%) (16. ábra).

A korábban bemutatott eredmények alapján a tioszulfát hidrogén termelésre kifejtett pozitív hatása az alábbi tényezőknek tulajdonítható:

i) képes ellátni elektronokkal a nitrogenázt a quinon raktáron keresztül

ii) növeli az in vitro nitrogenáz aktivitást (15. ábra)

iii) fokozza a PHA-k lebontását, több elektront juttatva a $\mathrm{H}_{2}$ termelésére A tioszulfát és PHA-k metabolizmus közötti molekuláris kölcsönhatás háttere, egyelöre nem ismert.

A korábban bemutatott közlemények (Maeda és mts., 1998; Maeda és mts., 2002). azt sugallták, hogy vizsgáljam meg egy másik elektrondonor, a borostyánkősav hatását is a PHA-k metabolizmusára és a nitrogenáz általi hidrogén termelésre. 

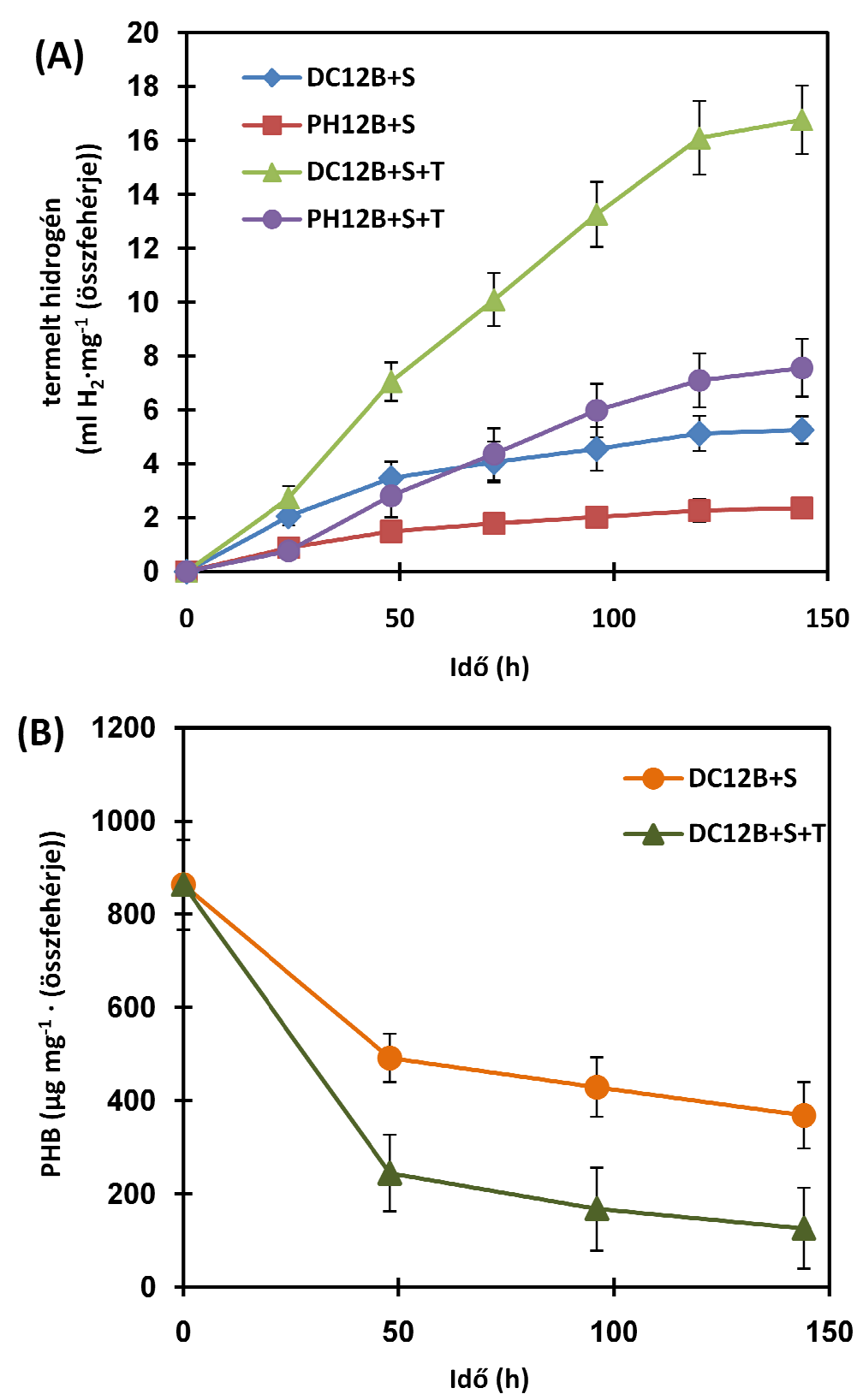

17. ábra. $A \mathrm{DC12B}$ és $\mathrm{PH} 12 \mathrm{~B}$ törzsek hidrogén termelése $(\mathrm{A})$ és a raktározott $\mathrm{PHB}$ mennyiségének a változása (B) borostyánkősav és/vagy tioszulfát jelenlétében. “+T" jelzés ellátott törzsek $2 \mathrm{~g} \mathrm{I}^{-1}$ tioszulfátot tartalmaztak, “+S" $5 \mathrm{gl}^{-1}$ borostyánkősavat tartalmaztak.

A kísérleteim azt mutatták, hogy borostyánkősav jelenlétében a poliésztert tartalmazó, valamint a $\Delta p h a$ sejtkultúrák esetében is megfigyelhető nitrogenázhoz kapcsolt hidrogén termelés, vagyis a borostyánkősav képes elektronokkal ellátni a nitrogenázt. 
A borostyánkősav hozzáadása gyakorlatilag megduplázta a termelt hidrogén mennyiségét mind a $\mathrm{DC12B}$, mind pedig a $\mathrm{PH} 12 \mathrm{~B}$ T. roseopersicina törzsekben $(5,24 \pm 0,5$ és 2,35 $\pm 0,35 \mu \mathrm{l} \mathrm{H}_{2} \mathrm{mg}^{-1}$ összfehérje) (17A. ábra és 14A. ábra), de ez jóval kisebb mértékű (kb. fele Isd. 14A. ábra), mind ahogyan ezt tioszulfát esetében tapasztaltam. A tioszulfát jelenlétében a DC12B és PH12B törzsek tioszulfát felhasználási kinetikájában tapasztalt korábbi kb. 40\%-os különbség, a borostyánkősav hozzáadását követően is megfigyelhető volt, de a HT tápoldat borostyánkősavval való kiegészítése csak kis mértékben befolyásolta a törzsek tioszulfát felhasználását (16. ábra), illetve a PHA-k lebomlását (17B. ábra).

A tioszulfát és borostyánkősav együttes adása arányosan növelte a termelt hidrogén mennyiségét a poliészter jelenlétében (DC12B) és hiányában ( $\mathrm{PH} 12 \mathrm{~B}$ ) is, így az 6. nap végére 7-8-szor nagyobb értéket mutatott $\left(16,76 \pm 1,13\right.$, illetve 7,55 $\pm 0,76 \mu \mathrm{H}_{2} \mathrm{mg}^{-1}$ összfehérje) a szén- és tioszulfát mentes közegben nevelt kultúrákhoz képest (17A. ábra és 14A. ábra).

A bemutatott kísérletek alapján megállapítható, hogy a tesztelt vegyületek közül (PHA-k, tioszulfát, borostyánkősav) a $T$. roseopersicina sejtekben a tioszulfát a legjobb szubsztrát a biohidrogén termelésére. A baktériumok a PHA-kat és a borostyánkősavat hasonló hatékonysággal képesek hidrogén termelésre felhasználni. Ezen túlmenően a tioszulfát és PHA-k között megfigyelhető metabolikus kapcsolatnak további pozitív hatása van a hidrogén termelésre.

\subsection{A THIOCAPSA ROSEOPERSICINA SZEREPE A GLOBÁLIS HIDROGÉN ANYAGCSERÉBEN}

A különböző $T$. roseopersicina hidrogenázai (Hyn, Hup, Hox1 és Hox2) hidrogén termelési hatékonyságát összehasonlítva egy sorrend állítható fel. Ez egy mesterséges sorrend, mely a hidrogenázok egyenkénti vizsgálatán alapszik és nem veszi figyelembe azon sokrétű metabolikus kapcsolatokat (kén-, glikogén-, ecetsav metabolizmus stb.), melyek egybefonódhatnak a hidrogén metabolizmussal illetve szabályozzák a hidrogenázok expresszióját, működését.

A hidrogenázok közül a legjobb hidrogén termelőnek a Hox1 hidrogenáz bizonyult. Fényen, $0,5 \mathrm{~g} \mathrm{I}^{-1} \mathrm{NaHCO}_{3}$ és $1 \mathrm{~g} \mathrm{I}^{-1}$ tioszulfát jenlétében a csak Hox1 hidrogenázt tartalmazó mutáns törzs $\sim 140 \mu \mathrm{l} \mathrm{H}$ /l kultúra/h termelt (Tengölics és mts., személyes közlés). Szoros 
kapcsolat figyelhető meg a kénanyagcsere, és a Hyn hidrogenáz között is (Laurinavichene és mtsai., 2007). A Hyn hidrogenáz $9 \mathrm{~g} \mathrm{l}^{-1}$ tioszulfát jelenlétében csak $\sim \mathbf{3 0} \boldsymbol{\mu l} \mathbf{H}_{\mathbf{2}} / \mathbf{l}$ kultúra/h is képes termelni (Tengölics és mts., személyes közlés). A legkisebb mennyiségben a Hox2 hidrogenáz képes hidrogént termelni ( $\sim \boldsymbol{7} \mathrm{H}_{2} / \mathrm{I}$ kultúra/h). Ez a hidrogén termelés a stacioner növekedési szakaszban figyelhető meg és a glükóz metabolizmushoz kapcsolt (Maróti és mts., 2010).

Fény jelenlétében, a $T$. roseopersicina [MoFe] nitrogenáza, a hidrogenázokhoz viszonyítva, nagy mennyiségű hidrogént képes termelni. Ez $4 \mathrm{~g} \mathrm{I}^{-1}$ tioszulfát jelenlétében $\sim 626 \mu \mathrm{H}_{\mathbf{2}} / \mathrm{l}$ kultúra/h, de $10 \mathrm{~g} \mathrm{l}^{-1}$ ecetsav jelenlétében ez a mennyiség a $\sim \mathbf{4} \mathbf{~} \mathrm{Hl}_{\mathbf{2}} / \mathrm{I}$ kultúra/h (Fülöp és mts., személyes közlés) mennyiséget is elérheti.

A tisztán polihidroxi-alkánsavak bontásából 14 $\mu \mathrm{l} \mathrm{H}_{2} / \mathrm{I}$ kultúra/h termelhető, míg PHA és tioszulfát jelenlétében ez a mennyiség elérheti a $75 \mu \mathrm{l} \mathrm{H}_{2} / \mathrm{I}$ kultúra/h.

A R. sulfidophilum sejtekben, ugyancsak batch fermentáció során a kizárólag PHB lebontásához kapcsolható hidrogén termelés elérheti a $\mathbf{3 3} \mathbf{~} \mathbf{~ H ~ H}_{2} / \mathbf{l}$ kultúra/h- is (Maeda és mts., 2002).

Nagyon lényeges kiemelni, hogy ezen hidrogén mennyiségeket a $T$. roseoprsicina- ún. batch fermentáció során termeli (nincs pH kontrol, szubsztrát utánpótlás stb) és nem folyamatos üzemú fermentorokban, ezért csak nagyon nagy fenntartással hasonlíthatóak össze az alábbi eredményekkel.

Folyamatos fermentorokban, a bíbor nem kén $\boldsymbol{R}$. spharoides és $\boldsymbol{R}$. rubrum fajok $\mathrm{H}_{2}$

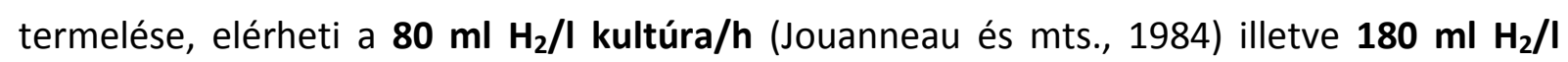
kultúra/h-t is.

$A z$ ismeretlen összetételü mezofil mikroba közösséget tartalmazó (főleg Clostridium spp.), rögzített ágyas bioreaktorokban, sötét fermentáció során a termelt hidrogén mennyisége elérheti a 3 I $\mathbf{H}_{2} / \mathbf{l}$ kultúra/h-t is (Chang és mts., 2002).

Ha a $T$. roseopersicina-ban a polihidroxi-alkánsavak metabolizmusához kapcsolt hidrogén termelést sikerülne pl. a Hox1 hidrogenázra "átruházni", akkor akár egy folyamatos hidrogén termelő rendszert lehetne létre hozni. Ezen rendszerben megvilágítás mellett a nitrogenáz (10 $\mathrm{gl}^{-1}$ ecetsav $\sim \mathbf{4} \mathrm{ml} \mathrm{H}_{2} \mathrm{l}^{-1}$ kultúra) lenne az ATP függő hidrogén termelő enzim, miközben a sejtek polihidroxi-alkánsavakat, (esetleg glikogént és elemi ként is) raktároznának, melyek bomlása során felszabaduló redukáló erőt, sötétben a Hox1 
hidrogenáz használná fel a biohidrogén előállítására. $R$. spharoides sejtekben azt találták, hogy a folyamatos fotoheterótróf és sötét fermentációs hidrogén termelés megvalósítható és hatékonyabb $\mathrm{H}_{2}$ termelést tesz lehetővé (Kim és mts., 2008).

Kars és Gündüz (2010) közleménye, nagyon jól összefoglalja egy “szuper hidrogén termelő törzs" létrehozásához szükséges genetikai módosításokat.

A korábbi irodalmi adatok és eredményeim is azt mutatják, hogy jelenleg a fotoszintézis alapú hidrogén termelő rendszerek (esetemben $T$. roseopersicina-ban a polihidroxi-alkánsavakon alapuló hidrogén termelő rendszer) nem képesek olyan mennyiségű $\mathrm{H}_{2}$-t termelni, hogy az hatékonyan hasznosítható legyen. Ennek ellenére ezen hidrogén termelő biológiai rendszerek, illetve a tartalék tápanyagok lehetséges szerepét a hidrogén termelésben további is ajánlott kutatni, mert az minden kétséget kizáróan a biohidrogén termelés hatékonyságának növelésében fog megnyilvánulni.

\subsection{EREDMÉNYEK ÖSSZEGZÉSE}

A $T$. roseopersicina hasonlóan a $A$. vinosum-hoz, illetve számos Archea és Eubaktériumhoz azon fajok közé tartozik, amelyek rendelkezik a PHA-k raktározásához és lebontásához szüksége génkészlettel és ecetsav jelenlétében a fototróf bíbor baktériumok közül az egyik legjobb PHA raktározó (kb. 31\%) fajok közé tartozik. A T. roseopersicina-ban a PHA-k bioszintézisében részt vevő gének fehérjeszekvenciája és genetikai térképe nagyfokú hasonlóságot mutat egy közeli rokona, az A. vinosum megfelelő pha lókuszához, azonban ez a nagyfokú hasonlóság nem terjed ki a PHA-k lebontásában részt vevő phaZ génre.

A nagyon konzervált PHA szintáz, PhaC alegységének, illetve a PhaZ fehérjék filogenetikai törzsfái megerősítették a bioszintézisben és a lebontásban érintett gén(ek) eltérő evolúciós eredetét. A poliészterek raktározási képesség egy nagyon ősi szerzemény, mely a folyamatosan változó környezetben evolúciós előnyt jelent.

A nagyon vátozatos és néha nagy számban jelen levő poliészterbontó enzimek (depolimerázok) lehetővé teszik a sejtek számára, hogy képesek legyenek a különböző típusú és eredetű granulumok hasznosítani.

Nitrogenáz genetikai háttéren (DC12B) a PHA-k szintézisére képtelen (PH12B) törzset létrehozva sikerült egy két lépcsős - a poliészterek lebontásából származó "redukálóerő" 
által meghajtott - hidrogén termelő rendszert optimalizálnom, bizonyítva, hogy a polihidroxialkánsavak jó szubsztrátjai a hidrogén termelésnek. Fényenergia felhasználásával, a poliészterek bontásból származó elektronokat a nitrogenáz, mint ATP függő hidrogenáz hasznosította a hidrogén termelésben.

Számos elektron gazdag szubsztrátot (tioszulfát, borostyánkősav) kipróbálva azt tapasztaltam, hogy elsősorban a tioszulfát növeli jelentősen a termelt hidrogén mennyiségét, a nitrogenáz aktivitás, illetve a PHA-k bontásának fokozása révén.

Eredményeim alkalmasak arra, hogy megfontoljuk és átgondoljuk a PHA-k szerepét, melyek szén- és elektronforrásként, illetve "bio-műanyagként", alternatívát jelenthetnek a környezetbarát biohidrogén előállításához és a szeméthegyek méretének csökkentéséhez. 


\section{FELHASZNÁLT IRODALOM}

Akkerman, I., Janssen, M., Rocha, J.M.S., Reith, J.H. and Wijffels, R.H. (2003) Photobiological hydrogen production: Photochemical efficiency and bioreactor design. In: Bio-methane \& Biohydrogen. Reith, J.H., Wijffels, R.H. and Barten, H. (eds.) The Netherlands: Dutch Biological Hydrogen Foundation.

Anderson, A.J., Dawes, E.A. (1990) Occurrence, metabolism, metabolic role and industrial uses of bacterial polyhydroxyalkanoates. Microbiol Rev 54:450-72.

Ausubel, F.M., Brent, R., Kingston, R.E., Moore, D.D., Seidman, J.G., Smith, J.A. and Struhl, K. (1996) Current protocols in molecular biology. New York: Wiley.

Behrends, A., Klingbeil, B., Jendrossek, D. (1996) Poly (3-hydroxybutyrate) depolymerases bind to their substrate by a C-terminal located substrate binding site. FEMS Microbiol Lett 143:191-4.

Betancourt, A., Yezza, A., Halász, A., Trea, H.V., Hawari, J. (2007) Rapid microwave assisted esterification method for the analysis of poly-3-hydroxybutyrate in Alcaligenes latus by gas chromatography. J Chrom 1154:473-6.

Bogorov, LV. (1974) The properties of Thiocapsa roseopersicina, strain BBS, isolated from an estuary of the White Sea. Mikrobiologiia 43:326-32.

Brandl, H., Gross, R.A., Lenz, R.W., Lloyd, R., Clinton Fuller, R. (1991) The accumulation of poly (3hydroxyalkanoates) in Rhodobacter sphaeroides. Arch Microbiol 155:337-40.

Braunegg, G., Sonnleitner, B. \& Lafferty, R.M. (1978) A rapid gas chromatographic method for the determination of poly- $\beta$ - hydroxybutyric acid in microbial biomass. Eur J Appl Microbiol Biotechnol 6:29-37.

Burgess, B.K., Lowe, D.J. (1996) The mechanism of molybdenum nitrogenase. Chem Rev 96:2983-3011

Burris, R.H. (1991) Nitrogenases J Biol Chem 266:9339-42.

Cammack, Freyand., R.M., Robson, R. (2001) Hydrogen as a fuel. Taylor \& Francis Inc., London and New York.

Chang, J.S., Lee, K.S., Lin, P.J. (2002) BioHydrogen Production with fixed-bed bioreactors. Int J Hydrogen Energy 27:1167-74.

Chisnell, J.R., Premakumar, R., Bishop, P.E.J. (1988) Purification of a second alternative nitrogenase from a nifHDK deletion strain of Azotobacter vinelandii. J Bacteriol 170:27-33. 
Chiu, H.J., Peters, J.W., Lanzilotta, W.N., Ryle, M.J., Seefeldt, L.C., Howard, J.B., Rees D.C. (2001) MgATP-bound and nucleotide-free structures of a nitrogenase protein complex between the Leu127 $\Delta$ Fe protein and the MoFe protein, Biochemistry 40:641-50.

Choi, G.G., Kim, H.W. and Rhee, Y.H. (2004) Enzymatic and non-enzymatic degradation of poly (3hydroxybutyrate-co-3-hydroxyvalerate) copolyesters produced by Alcaligenes sp MT-16. J Microbiol 42:346-52.

Colbeau, A., Kovács, K. L., Chabert, J., Vignais P. M. (1994) Cloning and seqencing of the structural (hupSLC) and accessory (hupDHI) genes for hydrogenase biosynthesis in Thiocapsa roseopersicina. Gene 140:25-31.

Dawes, E.A. (1992) Storage polymers in prokaryotes. In: Mohan, S., Daww, C., and Cole, J. (eds.) Prokaryotic Structure and Function: A New Perspective,. Cambridge University Press, Cambridge. pp. 81-122.

De Philippis, R., Ena, A., Guastini, M., Sili, C., Vincenzini, M. (1992) Factors affecting poly- $\beta$ hydroxybutyrate accumulation in cyanobacteria and in purple non-sulfur bacteria. FEMS Microbiol Rev 103:187-94.

Doi, Y., S. Kitamura, and H. Abe. (1995) Microbial synthesis of poly (3-hydroxybutyrate-co-3hydroxyhexanoate). Macromolecules 28: 4822-4828.

Duche, O., Elsen, S., Cournac, L., Colbeau, A. (2005) Enlarging the gas access channel to the active site renders the regulatory hydrogenase HupUV of Rhodobacter capsulatus $\mathrm{O}_{2}$ sensitive without affecting its transductory activity. FEBS J 272: 3899-908.

Eady, R.R. (1996) Structure-function relationships of alternative nitrogenases. Chem Rev 96:3013-30.

Einsle, O., Tezcan, A., Andrade, S.L.A., Schmid, B., Yoshida, M., Howard, J.C., Rees, D.C. (2002) Nitrogenase MoFe-protein at $1.16 \AA$ resolution: a central ligand in the FeMo-cofactor, Science 297:1696-700.

Fontecilla-Camps, J.C., Frey, M., Garcin, E., Hatchikian, C., Montet, Y., Piras, C., Vernede, X., Volbeda, A. (1997) Hydrogenase: a hydrogen-metabolizing enzyme. What do the crystal structures tell us about its mode of action? Biochimie 79: 661-6.

Frey, M. (2002) Hydrogenases: Hydrogen activating enzymes. Chem Bio Chem 3:153-60.

Fritsche, E., Paschos, E.A., Beisel, H.G., Böck, A., Huber R.J. (1999) Crystal structure of the hydrogenase maturating endopeptidase HYBD from Escherichia coli. J Mol Biol 288:989-98. 
Fuller, R.C. (1995) Polyesters and photosynthetic bacteria: from lipid cellular inclusions to microbial thermoplastics. In:Blankenship, R.E., Madigan, M.T., Bauer, C.E. (eds) Anoxygenic photosynthetic bacteria. Netherlands: Kluwer Academic Press;. pp. 1245-56.

Georgiadis, M.M., Komiya, H., Chakrabarti, P., Woo, D., Kornuc, J.J., Rees, D.C. (1992) Crystallographic structure of the nitrogenase iron protein from Azotobacter vinelandii. Science 257:1653-59

Gogotov, I.N., Zorin, N.A., Kondratieva, E.N. (1976) Purification and properties of hydrogenase from phototrophic bacterium Thiocapsa roseopersicina. Biokhimiia 41:836-42.

Guindon, S., Dufayard, J.F., Lefort, V., Anisimova, M., Hordijk, W., Gascuel, O. (2010) New Algorithms and Methods to Estimate Maximum-Likelihood Phylogenies: Assessing the Performance of PhyML 3.0. Syst Biol 59:307-21.

Hai, T., Hein, S., Steinbüchel, A. (2001) Multiple evidence for widespread and general occurrence of type-III PHA synthases in cyanobacteria and molecular characterization of the PHA synthases from two thermophilic cyanobacteria: Chlorogloeopsis fritschii PCC 6912 and Synechococcus sp. strain MA19. Microbiology 147:3047-60.

Hallenbeck, P. and Benemann, R. J. (2002) Biological hydrogen production; fundamentals and limiting processes. Int J Hydrogen Energy 27:1185-93.

Haywood, G.W., Anderson, A.J., Williams, G.A., Dawes, E.A., Ewing, D.F. (1991) Accumulation of a poly(hydroxyalkanoate) copolymer containing primarily 3-hydroxyvalerate from simple carbohydrate substrates by Rhodococcus sp. NCIMB 40126 Int J Biol Macromol 13:83-8.

Herrero, M., Lorenzo, V., Timmis, K.N. (1990) Transposon vectors containing non-antibiotic resistance selection markers for cloning and stable chromosomal insertion of foreign genes in gram-negative bacteria. J Bacteriol 172:6557-67.

Hoffmann, N., and Rehm, B.H.A. (2004) Regulation of polyhydroxyalkanoate biosynthesis in Pseudomonas putida and Pseudomonas aeruginosa. FEMS Microbiol Lett 237:1-7.

Hoffmann, N., Kessler, B., Witholt, B. (2001) Factors involved in the regulatory network of polyhydroxyalkanoate metabolism. J Biotechnol 86:97-104

Hustede, E., Steinbüchel, A., Schlegel, H.G. (1993) Relationship between the photoproduction of hydrogen and the accumulation of PHB in nonsulphur purple bacteria. Appl Microbiol Biotechnol 39:8793.

Inoue, H., H. Nojima, H. Okayama (1990) High efficiency transformation of Escherichia coli with plasmids. Gene $96: 23-8$. 
Jahn, A., Keuntje, B., Dorffler, M., Klipp, W., Oelze, J. (1994) Optimizing photoheterotrophic $\mathrm{H}_{2}$ production by Rhodobacter capsulatus upon interposon mutagenesis in the hupL gene. Appl Microbiol Biotechnol 40:687-90.

Jang, S.B., Seefeldt, L.C., Peters, J.W. (2000) Insights into nucleotide signal transduction in nitrogenase: structure of an iron protein with MgADP bound, Biochemistry 39:14745-52.

Jendrossek, D. and Handrick, R. (2002) Microbial degradation of polyhydroxyalkanoates. Annu Rev Microbiol 56:403- 32.

Jeong, H.S. and Jouanneau, Y. (2000) Enhanced nitrogenase activity in strains of Rhodobacter capsulatus that overexpress the rnf genes. J Bacteriol 182(5):1208-14.

Jia, Y., Kappock, T. J., Frick, T., Sinskey, A. J. and Stubbe, J. (2000) Lipases provide a new mechanistic model for polyhydroxybutyrate (PHB) synthases: characterization of the functional residues in Chromatium vinosum PHB synthase. Biochemistry 39:3927-36.

Joshi, M.H. and Tabita, R. F. (1996) A global two component signal transduction system that integrates the control of photosynthesis, carbon dioxide assimilation, and nitrogen fixation. Proc Natl Acad Sci USA 93:14515-20.

Jouanneau, Y., Lebecque, S., Vignais, P.M. (1984) Ammonia and light effect on nitrogenase activity in nitrogen-limited continuous cultures of Rhodopseudomonas capsulata: role of glutamate synthetase. Arch Microbiol 119:326-31.

Jouanneau, Y., Wong, B., Vignais, P.M. (1985) Stimulation by light of nitrogenase synthesis in cells of Rhodopseudomonas capsulata growing in N-limited continuous cultures. Biophys Acta 808:149-55.

Jurasek, L., and Marchessault, R.H. (2002) The role of phasins in the morphogenesis of poly(3hydroxybutyrate) granules. Biomacromolecules 3:256-61.

Kadouri, D., Jurkevitch, E. \& Okon, Y. (2003) Involvement of the reserve material poly-[ß]hydroxybutyrate in Azospirillum brasilense stress endurance and root colonization. Appl Environ Microbiol 69: 3244-250.

Kadouri, D., Jurkevitch, E. \& Okon, Y., Castro-Sowinski, S. (2005) Ecological and agricultural significance of bacterial polyhydroxyalkanoates. Crit Rev Microbiol 31:55-67.

Kang, H.O., Chung, C.W., Kim, H.W., Kim Y.B., and Rhee Y.H. (2001) Cometabolic production of copolyesters consisting of 3-hydroxyvalerate and medium-chain-length 3-hydroxyalkanoates by Pseudomonas sp. DSY-82. Antonie van Leeuwenhoek 80:185-91. 
Kars, G., Gündüz, U. (2010) Towards a super $\mathrm{H}_{2}$ producer: improvements in photofermentative biohydrogen production by genetic manipulations. Int J Hydrogen Energy 35(13):6646-56.

Kern, M., Klipp, W., and Klemme, J.H. (1994) Increased Nitrogenase-Dependent $\mathrm{H}_{2}$ photoproduction by hup mutants of Rhodospirillum rubrum. Appl Environ Microbiol 60:1768-74.

Kessler, B. and Witholt, B. (1999) Poly (3-hydroxyalkanoates) In: Encyclopedis of bioprocess technology: Fermentation, biocatalysis and bioseparation. John Wiley \& Sons Inc. New York, pp. 2024-40.

Kessler, B. and Witholt, B. (2001) Factors involved in the regulatory network of polyhydroxyalkanoate metabolism. J Biotechnol 86: 97-104

Khatipov, E, Miyake, J. \& Asada, Y. (1998) Accumulation of poly- $\beta$-hydroxybutyrate by Rhodopseudomonas sphaeroides on various carbon and nitrogen substrates. FEMS Microbiol Lett 162:39-45.

Kim, C.H., Newton W.E., Dean, D.R. (1995) Role of the MoFe protein alpha-subunit histidine-195 residue in FeMo-cofactor binding and nitrogenase catalysis. Biochemistry 34:2798-808.

Kim, J.E., Kim S.M., Lee, K.J. (2008) Hydrogen evolution under photoheterotrophic and dark fermentative conditions by recombinant Rhodobacter sphaeroides containing the genes for fermentative pyruvate metabolism of Rhodospirillum rubrum. Int J Hydrogen Energy 33:5131-6.

Knoll, M., Hamm, T.M., Wagner, F., Martinez, V. and Pleiss, J. (2009) The PHA Depolymerase Engineering Database: A systematic analysis tool for the diverse family of polyhydroxyalkanoate (PHA) depolymerases BMC Bioinformatics 10:89.

Kondratieva, E.N., Zhukov V.G., Ivanovsky R.N., Petushkova U.P., Monosov E.Z. (1976) The capacity of phototrophic sulfur bacterium Thiocapsa roseopersicina for chemosynthesis. Arch Microbiol 108:28792.

Kovács, Á.T., Rákhely, G., Balogh, J., Maróti, G., Cournac, L., Carrier, P., Mészáros, L. S., Peltier, G., Kovács, K. L. (2005/A) Hydrogen independent expression of hupSL genes in Thiocapsa roseopersicina BBS. FEBS J 272(18):4807-16.

Kovács, K.L., Bagyinka, C. (1990) Structural properties, functional states and physiological roles of hydrogenase in photosynthetic bacteria FEMS Microbiol Reviews 87: 407-41.

Kovács, K.L., Bagyinka, C., Tigyi, G. (1988) Proteolytic resistance and its utilization in purification of hydrogenase from Thiocapsa roseopersicina. Biochim Biophys Acta 935:166-72. 
Kovács, K.L., Fodor, B.D., Kovács, Á.T., Csanádi, G., Maróti, G., Balogh, J., Arvani, S., Rákhely, G. (2002) Hydrogenases, accessory genes and the regulation of [NiFe] hydrogenase biosynthesis in Thiocapsa roseopersicina. Int J Hydrogen Energy 27:1463-69.

Kovács, K.L., Kovács, Á.T., Maróti, G., Mészáros, L.S., Balogh, J., Latinovics, D., Fülöp, A., Dávid, R., Dorogházi, E., Rákhely, G. (2005/B) The hydrogenases of Thiocapsa roseopersicina. Biochem Soc Trans 33:61-3.

Kumar, A.S., Mody, K., Jha, B. (2007) Bacterial exopolysaccharides-a perception. J Basic Microbiol 47:103-17.

Laurinavichene, T.V., Rákhely, G., Kovács, K.L., Tsygankov, A.A. (2007) The effect of sulfur compounds on $\mathrm{H}_{2}$ evolution/consumption reactions, mediated by various hydrogenases, in the purple sulfur bacterium, Thiocapsa roseopersicina. Arch Microbiol. 188:403-10.

Lemoigne, M. (1926) Produits de dehydration et de polymerisation de l'acide ß-oxobutyrique. Bull Soc Chim Biol 8:770-82.

Lenz, R.W., Marchessault, R.H. (2005) Bacterial Polyesters: Biosynthesis, Biodegradable Plastics and Biotechnology. Biomacromolecules 6:1-8.

Liang, J., Burris, R.H. (1988) Hydrogen burst associated with nitrogenase-catalyzed reactions. Proc Natl Acad Sci USA 85:9446-50

Liebergesell, M., and Steinbüchel, A. (1992) Cloning and nucleotide sequences of genes relevant for biosynthesis of poly(3-hydroxybutyric acid) in Chromatium vinosum strain D. Eur J Biochem 209:135-50. Liebergesell, M., Hustede, E., Timm, A., Steinbüchel, A., Clinton Fuller, R., Lenz, R.W., Schlegel, H.G. (1991) Formation of poly(3- hydroxyalkanoates) by phototrophic and chemolithotrophic bacteria. Arch Microbiol 155:415-21.

Liebergesell, M., Schmidt, B., and Steinbüchel, A. (1992) Isolation and identification of granuleassociated proteins relevant for poly(3-Hydroxyalkanoic Acid) biosynthesis in Chromatium-vinosum D. FEMS Microbiol Lett 99:227-32.

Lowe, D.J., Thorneley, R.N.F. (1984) The mechanism of Klebsiella pneumoniae nitrogenase action Biochem J 224:877-909.

Luengo, J.M., García, B., Sandoval, A., Naharro, G., Olivera, E.R. (2003) Bioplastics from microorganisms. Curr Opinion Microbiol 6:251-60. 
Madison, L.L. and Huisman, G.W. (1999) Metabolic engineering of poly (3-hydroalkanoates): from DNA to plastic. Microbiol Mol Biol Rev 63:21-53.

Maeda, I., Chowdhury, W.Q., Idehara, K., Yagi, K., Mizoguchi, T., Akano, T., Miyasaka, H., Furutani, T., Ikuta, Y., Shioji, N., Miura, Y. (1998) Improvement of substrate conversion to molecular hydrogen by three-stage cultivation of a photosynthetic bacterium, Rhodovulum sulfidophilum. Appl Biochem Biotechnol 70-72:301-10.

Maeda, I., Idehara, K., Okayama, N., Miura, Y., Yagi, K., Mizoguchi, T. (1997) Poly(3hydroxybutyrate) as an endogeneous substrate for $\mathrm{H}_{2}$ evolution in Rhodovulum sulfidophilum. Biotechnol Lett 19:1209-12.

Maeda, I., Miyasaka, H., Umeda, F., Kawase, M., Yagi, K. (2002) Maximization of Hydrogen Production Ability in High-Density Suspension of Rhodovulum sulfidiphilum Cells Using Intracellular Poly (3hydroxybutyrate) as Sole substrate. Biotechnol Bioeng 81:474-81.

Maehara, A., Taguchi, S., Nishiyama, T., Yamane, T., and Doi, Y. (2002) A repressor protein, PhaR, regulates polyhydroxyalkanoate (PHA) synthesis via its direct interaction with PHA. J Bacteriol 184:3992-4002.

Maehara, A., Ueda, S., Nakano, H., and Yamane, T. (1999) Analyses of a polyhydroxyalkanoic acid granule associated 16-kilodalton protein and its putative regulator in the pha locus of Paracoccus denitrificans. J Bacteriol 181:2914-21.

Maróti G, Fodor BD, Rákhely G, Kovács ÁT, Arvani S and Kovács KL. (2003) Accessory proteins functioning selectively and pleiotropically in the biosynthesis of [NiFe] hydrogenases in Thiocapsa roseopersicina. Eur J Biochem 270:2218-27.

Maróti, J., Farkas, A., Nagy, I.K., Maróti, G., Kondorosi, E, Rákhely, G., Kovács, K.L. (2010) A second soluble Hox-type NiFe enzyme complete the hydrogenise set in Thiocapsa roseopersicina BBS. Appl Environ Microbiol. 76(15):5113-23.

Mas, J. and Van Gemerden, H. (1995) Storage products in purple and green sulfur bacteria. In: Anoxygenic Photosynthetic Bacteria. Blankenship R, Madigan M and Bauer, C (eds). Kluwer: Dordrecht;; pp. 973-90.

McCool, G.J. and Cannon, M.C. (2001) PhaC and PhaR are required forpolyhydroxyalkanoic acid synthase activity in Bacillus megaterium. J Bacteriol 183:4235-43

Müh, U., Sinskey, A. J., Kirby, D. P., Lane, W. S. and Stubbe, J. (1999) PHA synthase from Chromatium vinosum: Cys 149 is involved in covalent catalysis. Biochemistry 38:826-37. 
Newton, W.E. (2005) Nitrogen fixation, in: Kirk-Othmer Encyclopedia of Chemical Technology, John Wiley \& Sons, New York, NY.

Nojiri, M., Saito, T. (1997) Structure and function of poly (3-hydroxybutyrate) depolymerases from Alcaligenes faecalis T1. J Bacteriol 179:6965-70

Notredame, C., Higgins, D., Heringa, J. (2000) T-Coffee: A novel method for multiple sequence alignments. J Mol Biol 302(1):205-17.

Palágyi-Mészáros, L.S., Maróti, J., Latinovics, D., Balogh, T., Klement, E., Medzihradszky, K.F., Rákhely, G., Kovács, K.L. (2009) Electron-transfer subunits of the NiFe hydrogenases in Thiocapsa roseopersicina BBS. FEBS J 276:164-74.

Park, S.J., Choi, J.I. and Lee, S.Y. (2005) Engineering of Escherichia coli fatty acid metabolism for the production of polyhydroxyalkanoates. Enzyme Microb Technol 36: 579- 88.

Pau, R.N. (1994) Metals and nitrogenase, in: G.L. Eichhorn, L.G. Marzilli (eds.) Advances in Inorganic Biochemistry, Vol. 10, PTR Prentice Hall, New Jersey, pp. 49-70.

Peters, J.W., Stowell, M.B.H., Soltis, S.M., Finnegan, M.G., Johnson, M.K., Rees, D.C. (1997) Redoxdependent structural changes in the nitrogenase P-cluster, Biochemistry 36:1181-7.

Pfennig, N., Trüper, H.G..(1991) The family Chromatiaceae,. In A. Balows, H. G. Trüper, M. Dworkin, W. Harder, and K. H. Schleifer (eds.), The Prokaryotes. Springer-Verlag, Berlin, Heidelberg, New York, pp. 3200-21.

Philip, S., Keshavarz, T., Roy, I. (2007) Polyhydroxyalkanoates: biodegradable polymers with a range of applications. J Chem Technol Biotechnol 82:233-47.

Pimentel, D. (1991) Global warming, population growth, and natural resources for food production. Soc Nat Resour 4:347-63.

Pötter, M., Muller, H., Reinecke, F., Wieczorek, R., Fricke, F., Bowien, B., Friedrich, B. and Steinbüchel, A. (2004) The complex structure of polyhydroxybutyrate (PHB) granules: four orthologous and paralogous phasins occur in Ralstonia eutropha. Microbiology 150: 2301-11.

Prince, R.C., Kheshgi, H.S. (2005) The photobiological production of hydrogen: potential efficiency and effectiveness as a renewable fuel. Crit Rev Microbiol 31(1):19-31.

Rákhely, G., Colbeau, A., Garin, J., Vignais, P.M., Kovács, K. L. (1998) Unusual organization of the genes coding for HydSL, the stable (NiFe) hydrogenase in the photosynthetic bacterium Thiocapsa roseopersicina BBS. J Bacteriol 180:1460-65. 
Rákhely, G., Kovács, Á.T., Maróti, G., Fodor, B.D., Csanádi, G., Latinovics, D., Kovács, K.L. (2004) Cyanobacterial type, heteropentameric, $\mathrm{NAD}^{+}$reducing [NiFe] hydrogenase in the purple sulfur photosynthetic bacterium, Thiocapsa roseopersicina. App Environ Microbiol 70:722-8.

Rákhely, G., Laurinavichene, T.V., Tsygankov, A.A., Kovács, K.L. (2007) The role of Hox hydrogenase in the $\mathrm{H}_{2}$ metabolism of Thiocapsa roseopersicina. Biochim Biophys Acta. 1767:671-6.

Ratledge, C. and Kristiansen, B. (2001) Basic Biotechnology, 2nd edn. Cambridge: Cambridge University Press.

Rehm, B.H.A and Steinbüchel, A. (1999) Biochemical and genetic analysis of PHA synthases and other proteins required for PHA synthesis. Int J Biol Macromol 25:3-19.

Rehm, B.H.A. (2003) Polyester synthases: natural catalysts for plastics. Biochem J 376:15-33.

Rehm, B.H.A. (2007) Biogenesis of microbial polyhydroxyalkanoate granules: a platform technology for the production of tailor-made bioparticles. Curr Issues Mol Biol 9: 41-62.

Ribbe, M., Gadkari, D., Meyer, O. (1997) $\mathrm{N}_{2}$ fixation by Streptomyces thermoautotrophicus involves a molybdenum-dinitrogenase and a manganese-superoxide oxidoreductase that couple $\mathrm{N}_{2}$ reduction to the oxidation of superoxide produced from $\mathrm{O}_{2}$ by a molybdenum-CO dehydrogenase. $\mathrm{J}$ Biol Chem 272:26627-33.

Sambrook, J., Fritsch, E.F., Maniatis, T. (1989) Molecular cloning: a Laboratory Manual 2nd edition. New York: Cold Spring Harbor.

Sasikala, K., Ramana, C.V., Raghuveer Rao, P., Kovács, K.L. (1993) Anoxygenic phototrophic bacteria: Physiology and advances in hydrogen production technology. Adv Appl Microbiol 38:211-96.

Sawers, G. (1999) The aerobic/anaerobic interface. Curr Opin Microbio/ 2:181-187.

Schafer, A., Tauch, A., Jage,r W., Kalinowski, J., Thierbach, G., Pühler, A. (1994) Small mobilizable multi-purpose cloning vectors derived from the Escherichia coli plasmids pK18 and pK19: selection of defined deletions in the chromosome of Corynebacterium glutamicum. Gene 145:69-73.

Seefeldt, L.C., Hoffman, B.M., Dean, D.R. (2009) Mechanism of Mo-dependent nitrogenase Annu Rev Biochem 78:701-22.

Shangguan, Y.Y., Wang, Y.W., Wu, Q. and Chen, G.Q. (2006) The mechanical properties and in vitro biodegradation and biocompatibility of UV-treated poly(3-hydroxybutyrate-co- 3-hydroxyhexanoate). Biomaterials 27:2349-57. 
Shima, S., Thauer, R. K. (2007) A third type of hydrogenase catalyzing H2 activation. Chem. Rec. 7:3746.

Simpson, F.B., Burris, R.H. (1984) A nitrogen pressure of 50 atmospheres does not prevent evolution of hydrogen by nitrogenase. Science 224:1095-97

Steinborn, B. and Oelze, J. (1989). Nitrogenase and photosynthetic activities of chemostat cultures of Rhodobacter capsulatus 37b4 grown under different illuminations. Arch of Microb 152:100-104.

Steinbüchel, A. and Lütke-Eversloh, T. (2003) Metabolic engineering and pathway construction for biotechnological production of relevant polyhydroxyalkanoates in microorganisms. Biochem Eng J 16:81-96.

Steinbüchel, A., Füchtenbusch, B. (1998) Bacterial and other biological systems for polyester production. Trends Biotechnol 16: 419-27.

Stewart, W.D.P., Fitzgerald, G.P., Burris, R.H. (1967) In situ studies on $\mathrm{N}_{2}$ fixation using the acetylene reduction technique. Proc Natl Acad Sci USA 58(5):2071-8.

Suriyamongkol, P., Weselake, R., Narine, S., Moloney, M., Shah, S. (2007) Biotechnological approaches for the production of polyhydroxyalkanoates in microorganisms and plant-a review. Biotechnol Adv 25:148-75.

Thauer, R. K. (1998) Biochemistry of methanogenesis: a tribute to Marjory Stephenson. Microbiology 144:2377-406.

Thorneley, F.N.R. and Lowe, J.D. (1983) Nitrogenase of Klebsiella pneumoniae. Biochem J 215:393-403.

Thorneley, R.N.F., Lowe, D.J. (1985) Kinetics and mechanisms of the nitrogenase enzyme system. In Molybdenum Enzymes, Spiro, T.G.( ed.) New York:Wiley pp. 221-84.

Tokiwa, Y., and Calabia, B.P (2004) Degradation of microbial polyesters. Biotechnol Lett 26(15):1181-9.

Tromp, T.K., Shia, R.L., Allen, M., Eiler, J.M., Yung Y.L. (2003) Potential environmental impact of a hydrogen economy on the stratosphere. Science 300:1740-2.

Verlinden, R.A.J., Hill, D.J., Kenward, M.A., Williams, C.D. and Radecka, I. (2007) Bacterial synthesis of biodegradable polyhydroxyalkanoates. J Appl Microbiol 102:1437-49.

Vignais, P.M. (2008) Hydrogenases and $\mathrm{H}(+)$-reduction in primary energy conservation. Results Probl Cell Differ 45:223-52.

Vignais, P.M. and Billoud, B. (2007) Occurrence, classification, and biological function of hydrogenases: an overview. Chem Rev. 107:4206-72. 
Vignais, P.M., Billoud, B., Meyer, J. (2001) Classification and phylogeny of hydrogenases. FEMS Microbiol Rev 25:455-501.

Vincent, A.K., Parkin, A., Armstrong, A.F. (2007) Investigating and Exploiting the Electrocatalytic Properties of Hydrogenases. Chem Rev 107:4366-4413.

Volbeda A., Charon, M.H., Piras, C., Hatchikian, E.C., Frey, M., Fontecilla-Camps, J.C. (1995) Crystal structure of the nickel-iron hydrogenase from Desulfovibrio gigas. Nature. 373:580-7.

Wang, C., Sheng, X., Equi, R.C., Trainer, M.A., Charles, T.C., Sobral B.W. (2007) Influence of the poly3-hydroxybutyrate (PHB) granule-associated proteins (PhaP1 and PhaP2) on PHB accumulation and symbiotic nitrogen fixation in Sinorhizobium meliloti Rm1021 J Bacteriol 189:9050-56.

Wang, Z.C., Watt, G.D. (1984) $\mathrm{H}_{2}$-uptake activity of the MoFe protein component of Azotobacter vinelandii nitrogenase. Proc Natl Acad Sci USA 81:376-9.

Willis, L.B., and Walker, G.C. (1998) The phbC (poly- $\beta$-hydroxybutyrate synthase) gene of Rhizobium (Sinorhizobium) meliloti and characterization of phbC mutants. Can J Microbiol 44:554-64.

Worin, N.A., Lissolo, T., Colbeau, A., Vignais, P.M. (1996) Increased hydrogen photoproduction by Rhodobacter capsulatus strains deficient in uptake hydrogenase. J Mar Biotechnol 4:28-33.

Wu, Q., Wang, Y., Chen, G,Q. (2009) Medical application of microbial biopolyesters polyhydroxyalkanoates. Artif Cells Blood Substit Biotechnol 37:1-12.

Yan, Q., Sun, Y., Ruan, L.F., Chen, J. and Yu, P.H.F. (2005) Biosynthesis of short-chain-lengthpolyhydroxyalkanoates during the dual-nutrient-limited zone by Ralstonia eutropha. World J Microbiol Biotechnol 21:17-21.

York, G.M., Stubbe, J., and Sinskey, A.J. (2002). The Ralstonia eutropha PhaR protein couples synthesis of the PhaP phasin to the presence of polyhydroxybutyrate in cells and promotes polyhydroxybutyrate production. J Bacteriol 184: 59-66.

Yuan, W., Jia, Y., Tian, J., Snell, K.D., Muh, U., Sinskey, A.J., Lambalot, R.H., Walsh, C.T. and Stubbe, J. (2001) Class I and III polyhydroxyalkanoate synthases from Ralstonia eutropha and Allochromatium vinosum: characterization and substrate specificity studies. Arch Biochem Biophys 394: 87-98.

Zhao, H.Y., Li, H.M., Qin, LF., Wang, H.H., Chen, G.Q. (2007) Disruption of the polyhydroxyalkanoates synthase gene in Aeromonas hydrophila reduces its survival ability under stress conditions. FEMS Microbiol Lett 276:34-41. 
Zinn, M., Witholt, B. and Egli, T. (2001) Occurrence, synthesis and medical application of bacterial polyhydroxyalkanoate. Adv Drug Deliv Rev 53:5-21. 


\section{SAJÁT KÖZLEMÉNYEKJEGYZÉKE}

\subsection{A DISSZERTÁCIÓ ALAPJÁUL SZOLGÁLÓ KÖZLEMÉNYEK}

Fülöp, A., Béres, R., Tengölics, R., Rákhely, G., Kovács, K.L. (2012) Relationship between PHA and hydrogen metabolism in the purple sulfur phototrophic bacterium Thiocapsa roseopersicina BBS. Közlésre elfogadva Int J Hydrogen Energy.

Fülöp, A., Rákhely, G,, Kovács, K.L. Polyhydroxyalkanoates role in hydrogen production in a purple sulphur bacteria. $7^{\text {th }}$ European Workshop on Bacterial Respiratory Chains, 2011, Május 11-15, Backagarden, Svédország.

Rákhely, G., Béres, R., Fülöp, A., Latinovics, D. and Kovács, K.L. Connection between hydrogen metabolism and biopolymer storage materials in purple photosynthetic bacteria. Biotechnical Functionalisation of Renewable Polymeric Materials COST 868 meeting. 2008, Április 17-18, Pozsony, Szlovákia.

\subsection{A DISSZERTÁCIÓHOZ NEM KAPCSOLODÓ, EGYÉB KÖZLEMÉNYEK}

\subsubsection{TELJES KÖZLEMÉNYEK}

Kiss, I., Oskolás, H., Tóth, R., Bouillet, P., Tóth, K., Fülöp, A., Scholtz, B., Ledent, C.A., Fésüs, L. and Szondy, Z. (2006) Adenosine A2A receptor-mediated cell death of mouse thymocytes involves adenylate cyclase and Bim and is negatively regulated by Nur77. Eur J Immunol 36:1559-71.

IF: 5,005

Kovács, Á.T., Rákhely, G., Browning, D.F., Fülöp, A., Maróti, G., Busby, S.J.W., Kovács, K.L. (2005). An FNR-type regulator controls the anaerobic expression of Hyn hydrogenase in Thiocapsa roseopersicina. J Bacteriol 187(8):2618-27.

IF: 4,175 
Kovács, Á.T, Rákhely, G., Balogh, J., Maróti, G., Fülöp, A., Kovács, K.L. (2005) Anaerobic regulation of hydrogenase transcription in different bacteria. Biochem Soc Trans 33(1):36-8. IF: 2,579

Kovács, K.L., Kovács, Á.T., Maróti, G., Mészáros, L.S., Balogh, J., Latinovics, D., Fülöp, A., Dávid, R., Dorogházi, E., Rákhely, G. (2005) The hydrogenases of Thiocapsa roseopersicina. Biochem Soc Trans 33(1):61-3.

IF: 2,579

Kovács, K.L., Kovács, Á.T., Maróti, G., Bagi, Z., Csanádi, Gy., Perei, K., Bálint, B., Balogh, J., Fülöp, A., Mészáros, L.S., Tóth, A., Dávid, R., Latinovics, D., Varga, A., Rákhely, G. (2004) Improvement of biohydrogen production and intensification of biogas formation. Rev Environ Sci Biotechnol 3:321-30.

IF: 0,876

Kovács, K.L, Fülöp, A., Herbel, Z., Nyilasi, A., Rákhely, G. (2010) Tiszta, megújuló energia a biohidrogén, Környezetvédelem XVIII.(2):20-21

Összesített impakt faktor: 19,267

\subsubsection{POSZTER KÖZLEMÉNYEK}

Béres, R., Fülöp, A., Szász, I., Kovács, L.K., Zinn, M. \& Rákhely, G. Biopolymers in phototrophic bacteria: special bioplastics and source of biofuels. $7^{\text {th }}$ International Conference on Polymer and Textile Biotechnology. 2011, Március 02-04, Milánó, Olaszország.

Rákhely, G., Balogh, J., Balogh, T., Fülöp, A., Győri, E., Latinovics, D., Palágyi- Mészáros, L.S., Novák, J., Tengölics, R. \& Kovács, K.L. Synthesis and utilization of biopolymers in purple photosynthetic bacteria. First annual workshop of the COST 868 Action on Biotechnical functionalisation of renewable polymeric materials. 2007, Szeptember12-14, Grác, Ausztria. 
Fülöp, A., Kovács, Á.T., Klem, J., Rákhely, G., Kovács, K.L. The function and regulation of the fnrt gene in the purple sulfur photosynthetic Thiocapsa roseopersicina BBS. Modern Trends in Biological Sciences: Seeking an Integrative approach $1^{\text {st }}$ ITC Alumni Meeting, Szegedi Biológiai Központ. 2006, Október 19-20, Szeged, Magyarország.

Fülöp, A., Kovács, Á.T., Klem, J., Rákhely, G., Kovács, K.L. The function and regulation of the fnrt gene in the purple sulfur photosynthetic bacterium. Straub Napok, Szegedi Biológiai Központ. 2006, November 15-17, Szeged, Magyarország.

Maróti, G., Bagi, Z., Rákhely, G., Takács, M., Tóth, A., Kovács, Á.T., Bálint, B., Mészáros, L.S., Balogh, J., Fülöp, A., Latinovics, D., Dávid, R., Dorogházi, E., Nyilasi, A., Kovács, K.L. Biohydrogen, biogas. Biovision. 2005 Április 11-15, Lyon, Franiaország.

Kovács, Á.T, Rákhely, G., Browning, D.F., Fülöp, A., Maróti, G., Busby, S.J.W., Kovács, K.L. An FNR-type regulator controls the anaerobic expression of Hyn hydrogenase in Thiocapsa roseopersicina. Straub Napok, Szegedi Biológiai Központ. 2004, December 7-9, Szeged,

\section{Magyarország.}

Kovács, Á.T., Rákhely, G., Browning, D.F., Fülöp, A., Maróti, G., Busby, S.J.W., Kovács, K.L. An FNR-type regulator controls the anaerobic expression of Hyn hydrogenase in Thiocapsa roseopersicina. International Hydrogenase Conference. 2004, Augusztus 24-29, Reading, Nagy Britannia.

Kovács, Á.T, Rákhely, G., Fülöp, A., Browning, D.F., Busby, S.J.W., Kornél, K.L. FNR, anaerob regulátor egy fototóf baktériumban. Magyar Biokémiai Egyesület Kongresszusa. 2004 Május 10-13, Sopron, Magyarország.

Kovács, Á.T., Rákhely, G., Maróti, G., Balogh, J., Latinovics, D., Fülöp, A., Busby, S., Kovács, K.L. Regulation by light, oxygen and hydrogen in a purple sulfur photosynthetic bacterium. 
Conference on Molecular Microbiology: Exploring Prokaryotic Diversity. 2004, Április 22-26, Heidelberg, Németország.

\subsubsection{KONFERENCIA ELÖADÁSOK}

Fülöp, A., Rákhely, G., Kovács, K.L. (2010). Biopolimerek. 11. Biológus Napok, Március 23-24 Kolozsvár, Románia.

Fülöp, A. (2009). Regulatory and metabolic context of hydrogenases and acetate. Hyvolution, WP3 meeting, Április 15-16, Szegedi Tudományegyetem, Biotechnológiai Tanszék, Magyarország.

Fülöp, A. (2008). "Valós idejü" polimeráz láncreakció. 9. Biológus Napok, Április 24-25, Kolozsvár, Románia.

Fülöp, A., Kovács, Á.T., Klem, J., Rákhely, G., Kovács ,K.L. (2006). Két-dimenziós gélelektroforézis. 7. Biológus Napok, Március 23-24, Kolozsvár, Románia.

Fülöp, A., Kovács, Á.T., Klem, J., Rákhely, G., Kovács, K.L. (2005). The function and regulation of fnrT-gene in Thiocapsa roseopersicina. $5^{\text {th }}$ International Conference of PHD Students, Augusztus 14-20, Miskolc, Magyarország.

Fülöp, A., Kovács, Á.T., Rákhely, G., Kovács, K.L. (2005). Az fnrT-gén szerepe és szabályozása a Thiocapsa roseopersicina fototróf bíbor kénbaktériumban. 6. Biológus Napok, Április 22-23 Kolozsvár, Románia. 


\section{KÖSZÖNETNYILVÁNÍTÁS}

Köszönetemet szeretném kifejezni mindazoknak számára, akik az SzTE Biotechnológiai Tanszékén és az MTA Szegedi Biológiai Központ Biofizikai Intézetében támogattak, bátorítottak.

Külön köszönet mondok,

Témavezetőimnek:

Dr. Rákhely Gábornak

a szakmai tanításért, tanácsaiért,

Prof. Kovács Kornélnak

amiért megteremtette a kutatás feltételeit és támogatta többéves kutatói fejlődésemet.

További köszönet illeti, különösen

Dr. Kovács Ákost

aki a pályám elején egyengette az utamat és bevezetett a molekuláris biológia rejtelmeibe, Tengölics Rolandot

az érdekes szakmai beszélgetésekért és eszmecserékért,

Szász Istvánt

kitartó és lelkes munkájáért, valamint

Mandred Zinnt, Thomas Ramsauert

a svájci kiruccanás során nyújtott segítségükért.

Köszönöm a Redox Metalloenzim csoport minden egykori és jelenlegi tagjának a munkám sikeréhez való hozzájárulásukat, valamint

Verebély Rózsának, Katonáné Lehoczky Klárának és Dobó Krisztának a technikai segítségét.

Hálával és leírhatatlan köszönettel tartozom feleségemnek, Melindának és fiamnak Nándusnak valamint édesanyámnak, Rebekának és húgomnak, Anettának és családjának, hogy tanulmányaim hosszú évei alatt mindvégig támaszaim voltak, bíztattak és mindig szerető családi légkörrel vettek körül. Hála illeti édesapámat, akinek szavai “ Az embert nem singgel mérik” elkísérnek egész életemben. 


\section{0. ÖSSZEFOGLALÁS}

A fototróf baktériumban raktározott PHA-k elsősorban szén és energia forrást jelentenek a sejtek számára, de megfelelő körülmények között hidrogén termelésére is felhasználhatóak

A polihidroxi-alkánsavak raktározása általában valamilyen tápanyagkomponens - pl nitrogén vagy foszfor - hiányában indul be. A dolgozatban olyan nitrogén limitált körülményeket alkalmaztunk, ahol a nitrogenáz múködésbe lép és hidrogént termel. Ilyen körülmények között a hidrogenázok a hidrogén oxidációját katalizálják, ezért kísérleteimhez egy aktív hidrogenázokat nem tartalmazó $T$. roseopersicina törzset (DC12B) választottam.

A vizsgálatok során a következő eredményeket értem el:

I. Számos szénforrást tesztelve (ecetsav, piroszőlősav, borostyánkősav) az ecetsav bizonyult a PHA-k raktározásához optimális szubsztrátnak, illetve az általam vizsgált körülmények között a raktározásához ideális $\mathrm{C} / \mathrm{N}$ arányt (122:1) a $10 \mathrm{~g} \mathrm{I}^{-1}$ acetát és $0,17 \mathrm{~g}$ $\mathrm{I}^{-1}$ glutamát biztosította. Ezen körülmények között a sejtek száraz tömegének kb. 31\%-t polihidroxi-alkánsavak alkották.

II. A T. roseopersicina genom adatbázisában azonosítottam és jellemeztem a PHA-k bioszintézisében (phaBPRACE) és lebontásában (phaz) részt vevő két genomi régiót.

III. A PhaC és PhaZ fehérjék filogenetikai törzsfáit összehasonlítva jelentős eltérést találtam, mely a PHA-k szintézisében és degradációjában részt vevő enzim(ek) egymástól független evolúciójára és egy lehetséges horizontális géntranszferre utal.

IV. A PHA-k hidrogén anyagcserében betöltött szerepének vizsgálatához egy PHA-k bioszintézisében mutáns törzset (PH12B) hoztam létre aktív hidrogenázt nem tartalmazó törzsben, mely sejtvonal nem volt képes poliésztereket felhalmozni. 
V. A PHA-k raktározást és a hidrogén termelést elkülönítve sikerült egy hatékony kétlépcsős hidrogén termelő rendszert optimalizálnom.

VI. Külső szén-, nitrogén- és elektronforrás hiányában a DC12B és PH12B törzsek hidrogén termelését összehasonlítva, a poliésztert tartalmazó sejtekben (DC12B) jelentősen magasabb hidrogén termelést figyeltem meg. A hidrogén termelésben tapasztalt számszerű különbség a poliészterek degradációjából származtatható, amit a poliészterek mennyiségének csökkenése is alátámaszt.

VII. Kimutattam, hogy a tápoldat kiegészítése tioszulfáttal (a $\mathrm{CO}_{2}$ asszimiláció elsődleges elektron forrása) mindkét törzsben fokozza hidrogén termelést. Ez a hatás a tioszulfát többirányú szerepének tulajdonítható: i) elektronokkal látja el a nitrogenázt a quinon raktáron keresztül, ii) fokozza az in vitro nitrogenáz aktivitást, iii) eddig ismeretlen mechanizmus révén fokozza a poliészterek bomlását. 


\section{SUMMARY}

In the phototropic bacteria, the accumulated PHAs are mainly carbon and energy sources, but under certain circumstances PHA can be used for hydrogen production.

PHA is accumulated during nutrient starvation such as nitrogen or phosphorous limitations. In my work, nitrogen fixing conditions were used leading to nitrogenase mediated hydrogen evolution. In this case, hydrogenases reoxidize hydrogen for recovering energy for the cells, therefore in my experiments a strain lacking any hydrogenase activity was used.

In this study the following results were achieved:

I. Among various substrates, acetate $\left(10 \mathrm{~g} \mathrm{l}^{-1}\right)$ supplemented with $0.17 \mathrm{~g} \mathrm{l}^{-1}$ glutamate was found to be the best carbon source for PHA accumulation. Under these conditions $T$. roseopersicina was able to accumulate PHA up to $33 \%$ of the dry cell weight.

II. Using the $T$. roseopersicina genomic database I have identified and characterized the genes involved in PHA biosynthesis (phaBPRACE) and degradation (phaZ).

III. A comparison of the phylogenetic trees of the PhaC and PhaZ proteins revealed significant differences, which indicated their different evolutionary histories and a possible horizontal gene transfer event.

IV. In order to test the role of polyesters in hydrogen metabolism, I prepared a PHAs biosynthetic mutant strain (PH12B) on a hydrogenase free background (DC12B). In the PH12B strain, no PHAs accumulation could be detected according to my expectations.

V. I optimized a dual-stage efficient hydrogen production system for $T$. roseopersicina, where the PHA accumulating growth conditions and $\mathrm{H}_{2}$-producing phases are temporally separated. 
VI. I demonstrated that the stored PHAs are good substrate for $\mathrm{H}_{2}$ production. Comparing the hydrogen production of $\Delta p h a$ and its corresponding parenteral strain, significantly higher $\mathrm{H}_{2}$ production could be observed in the presence of polyesters which correlated well with the increased PHB degradation rate.

VII. I found that the addition of primary electron sources (thiosulphate and/or succinate) to the $\mathrm{H}_{2}$-producing medium substantially increased the $\mathrm{H}_{2}$ production in both strains. This effect might be due to the multiple role of thiosulphate capable of: i) feeding electrons to the nitrogenase via quinone pool, ii) enhancing the in vitro nitrogenase activity, iii) stimulating the PHA degradation via an unknown mechanism. 